\title{
SELEÇÃO PARA PROLIFICIDADE EM POPULAÇÕES DE MILHO (Zea mays L.)
}

\author{
ANDréa Pizala
}

Engenheiro Agrônomo

Orientador: Prof. Dr. JOSÉ BRANCO DE MIRANDA FILHO

Tese apresentada à Escola Superior de Agricultura "Luiz de Queiroz", Universidade de São Paulo, para obtenção do título de Doutor em Agronomia, Área de Concentração: Genética e Melhoramento de Plantas.

PIRACICABA

Estado de São Paulo - Brasil

Fevereiro - 2000 
Dados Internacionais de Catalogação na Publicação (CIP)

DIVISĀO DE BIBLIOTECA E DOCUMENTAÇĀO - Campus "Luiz de Queiroz"/USP

Pizaia, Andréa

Seleção para prolificidade em populações de milho (Zea mays L.) / Andréa Pizaia. - Piracicaba, 2000.

$146 \mathrm{p}$.

Tese (doutorado) - Escola Superior de Agricultura Luiz de Queiroz, 2000.

Bibliografia.

1. Genética de população 2. Milho 3. Parâmetro genético 4. Prolificidade 5. Seleção genética vegetal I. Título

CDD 633.15

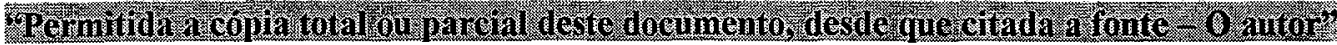




\section{AGRADECIMENTOS}

Ao Prof. Dr. José Branco de Miranda Filho pela oportunidade da realização deste trabalho e a orientação durante sua execução;

À FAPESP pela concessão da bolsa, a qual possibilitou custear as despesas de pesquisa; Ao Departamento de Genética da ESALQ/USP e aos seus professores pelo curso de doutorado;

Aos colegas Josué Maldonado Ferreira e Amadeu Regitano Neto pela ajuda nas polinizações;

Ao colega Cláudio Takeda pela correção dos manuscritos da tese;

Aos funcionários do Departamento de Genética, especialmente à Marcos Cella, Pipo, José Monteiro, Seu Sebastião e a todos os funcionários que trabalharam no campo;

À Cacilda, Cassiana, Adriana, Nereu e Juraci pelo constante estímulo. 
Esta tese é dedicada à

Nelson Florêncio Pizaia (in memorian) Exemplo de pai e cidadão,

e à

Amarildo José com amor 


\section{SUMÁRIO}

Página

LISTA DE FIGURAS ....................................................................... vi

LISTA DE TABELAS............................................................................... vii

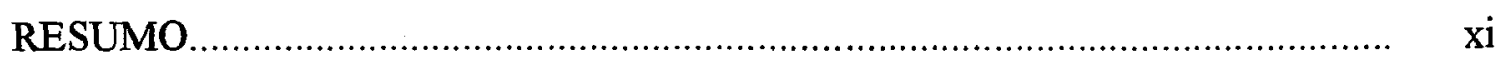

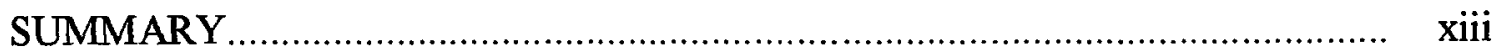

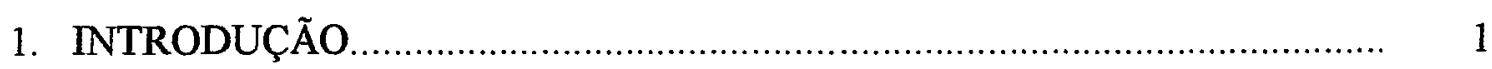

2. REVISÃO DE LITERATURA................................................................ 3

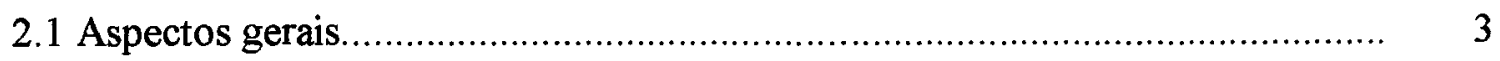

2.2 A prolificidade no milho ........................................................................... 4

2.2.1 A morfologênese floral............................................................................. 4

2.2.2 A ocorrência da dominância apical no milho................................................ 5

2.3 As condições ambientais e a expressão da prolificidade.................................. 7

2.3.1 Efeito do nitrogênio............................................................................... 7

2.3.2 Efeito da deficiência hídrica......................................................................

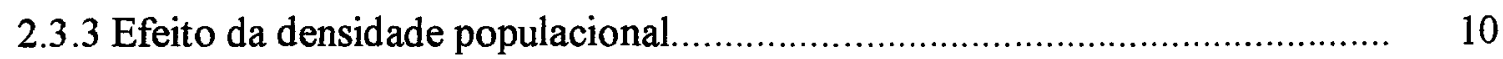

2.3.4 Eficiência da utilização do nitrogênio......................................................... 12

2.4 Herança da prolificidade........................................................................... 14

2.5 A correlação de prolificidade com a produção de grãos ................................... 17

2.6 A seleção recorrente e a prolificidade ............................................................ 20

3. MATERIAL E MÉTODOS........................................................................ 25

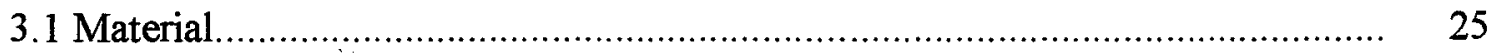

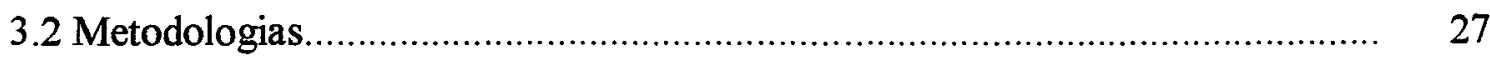

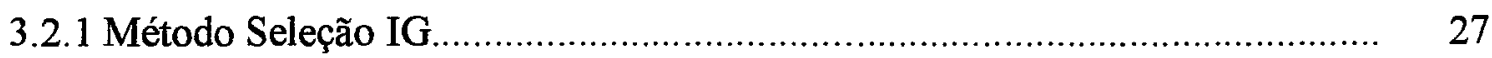

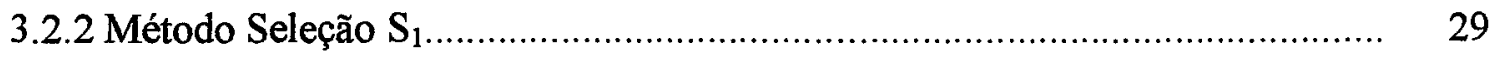

3.2.3 Obtenção das progênies e cruzamentos...................................................... 31

3.2.4 Instalação dos experimentos......................................................................... 35 
3.2.5 Análise estatística dos dados dos experimentos............................................. 39

3.2.5.1 Análise de variância e estimação dos parâmetros genéticos......................... 39

3.2.5.2 Progressos e respostas correlacionadas, esperadas com a seleção............... 42

4. RESULTADOS E DISCUSSÃO................................................................... 48

4.1 Médias das populações nos ciclos de seleção................................................. 48

4.2 Análise de variância e estimativa dos parâmetros genéticos.............................. 54

4.2.1 Primeiro ciclo....................................................................................... 54

4.2.2 Segundo ciclo

4.3 Ganho genético e resposta correlacionada.................................................. 62

4.4 Depressão por endogamia....................................................................... 70

4.5 Análise conjunta dos experimentos de segundo ciclo.................................... 71

4.6 Dados de espiga das progênies.................................................................... 74

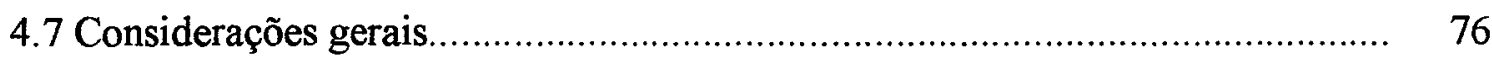

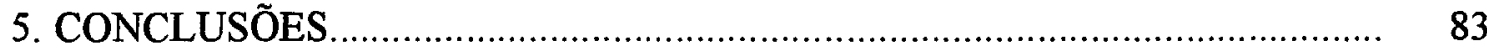

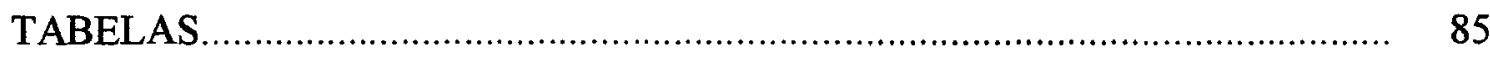

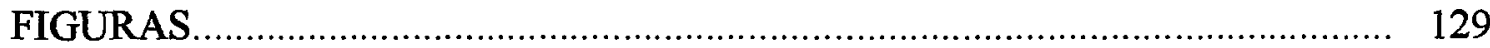

REFERÊNCIAS BIBLIOGRÁFICAS ......................................................... 135 


\section{LISTA DE FIGURAS}

\section{Página}

1 Esquema de seleção recorrente do método Seleção IG......................................... 28

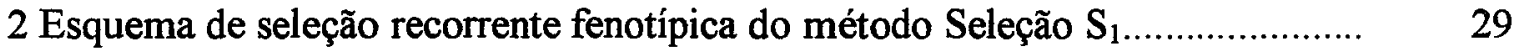

3 Médias da herdabilidade da prolificidade das populações de milho nos ciclos de seleção

4 Número de espigas por planta das populações de milho nos ciclos de seleção para prolificidade do método Seleção IG.

5 Número de espigas por planta das populações de milho nos ciclos de seleção para prolificidade do método Seleção $S_{1}$

6 Depressão por endogamia da prolificidade e da produção de espigas das populações nos dois ciclos de seleção

7 Médias do comprimento, diâmetro e peso de grãos das segundas espigas das populações de milho nos dois ciclos de seleção no método Seleção $S_{1}$ 


\section{LISTA DE TABELAS}

Página

1 Número de progênies de milho obtidas nos métodos intrapopulacionais Seleção IG e Seleção $S_{1}$, no primeiro e no segundo ciclo de seleção..

2 Relação dos experimentos instalados em 1997 e 1999 para avaliação das progênies de milho de primeiro e no segundo ciclo dos métodos de Seleção IG e Seleção $S_{1}$

3 Esquema da análise de variância em blocos ao acaso.

4 Esquema de análise de variância conjunta dos experimentos.

5 Análise de covariância da produção de espigas (médias de parcela) com o número de espigas por planta (médias de parcela).

6 Médias do Ciclo $0\left(\mathrm{C}_{0}\right)$, Ciclo $1\left(\mathrm{C}_{1}\right)$ e testemunha das populações de milho submetidas ao método Seleção IG. Anhembi (SP), 1999.

7 Médias do Ciclo $0\left(\mathrm{C}_{0}\right)$, Ciclo $1\left(\mathrm{C}_{1}\right)$ e testemunha das populações de milho submetidas ao método Seleção IG. Piracicaba (SP), 1999.

8 Médias do Ciclo $0\left(\mathrm{C}_{0}\right)$, Ciclo $1\left(\mathrm{C}_{1}\right)$ e testemunha das populações de milho submetidas ao método Seleção $\mathrm{S}_{1}$. Anhembi (SP), 1999.

9 Médias do Ciclo $0\left(\mathrm{C}_{0}\right)$, Ciclo $1\left(\mathrm{C}_{1}\right)$ e testemunha das populações de milho submetidas ao método Seleção $\mathrm{S}_{1}$. Anhembi (SP), 2000

10 Componentes de variância, média e a herdabilidade do peso de espigas ( $\mathrm{PE})$, peso de grãos (PG) e número de espigas por planta (NEP) em progênies de milho de primeiro ciclo dos métodos Seleção IG e Seleção $S_{1}$. Anhembi (SP), 1997.

11 Componentes de variância, média e a herdabilidade do peso de espigas (PE), peso de grãos (PG) e número de espigas por planta (NEP) em progênies de milho de primeiro ciclo do método Seleção IG. Anhembi e Piracicaba (SP), 1999 
12 Componentes de variância, média e a herdabilidade do peso de espigas (PE), peso de grãos (PG) e número de espigas por planta (NEP) em progênies de milho de segundo ciclo do método Seleção $S_{1}$. Anhembi (SP), 1999 e 2000....

13 Ganho genético esperado e realizado em porcentagem nos dois ciclos seletivos das populações de milho submetidas aos métodos Seleção IG e Seleção S $_{1}$ (entre parênteses). Piracicaba e Anhembi (SP), 1997 e 1999.

14 Estimativa da correlação genética $\left(\hat{r}_{g}\right)$ e correlação fenotípica $\left(\hat{r}_{f}\right)$ entre o número de espigas por planta (NEP) e a produção de espigas (PE) nas populações de milho submetidas aos métodos Seleção $I G$ e Seleção $S_{1}$ (entre parênteses). Anhembi e Piracicaba (SP), 1999.

15 Resposta correlacionada estimada e realizada em porcentagem da seleção para a prolificidade sobre a produção de espigas $\left(\mathbf{R}_{\mathrm{PE}, \mathrm{NEP}}\right)$, nas populações de milho submetidas aos métodos Seleção IG e Seleção $S_{1}$ (entre parênteses). Anhembi e Piracicaba (SP), 1997 e 1999.

16 Valores mínimos, máximos, a média e do desvio padrão $\left(s_{\bar{x}}\right)$ dos dados de espiga das progênies de milho obtidas no método Seleção $S_{1}$ no primeiro ciclo. Anhembi, 1997.

17 Valores mínimos, máximos, a média e do desvio padrão $\left(s_{\bar{x}}\right)$ dos dados de espiga das progênies de milho obtidas no método Seleção $S_{1}$ e Seleção IG no segundo ciclo. Piracicaba, 1998.

18 Análise de variância da população de milho Piranão VF1B no primeiro ciclo de seleção dos métodos Seleção IG e Seleção $\mathrm{S}_{1}$. Anhembi, 1997

19 Análise de variância da população de milho Piranão VD2B no primeiro ciclo de seleção dos métodos Seleção IG e Seleção $S_{1}$. Anhembi, 1997

20 Análise de variância da população de milho Pichilingue no primeiro ciclo de seleção dos métodos Seleção IG e Seleção $S_{1}$. Anhembi, 1997

21 Análise de variância da população de milho ITA-PR no primeiro ciclo de seleção dos métodos Seleção IG e Seleção $\mathrm{S}_{1}$. Anhembi, 1997. 
22 Análise de variância da população de milho ESALQ-PR1 no primeiro ciclo de seleção dos métodos Seleção IG e Seleção $S_{1}$. Anhembi, 1997.

23 Análise de variância da população de milho Piranão VD2B-P no primeiro ciclo de seleção dos métodos Seleção IG. Anhembi, 1997.

24 Análise de variância da população de milho Piranão VF1B-P no segundo ciclo de seleção do método Seleção IG. Anhembi e Piracicaba, 1999.

25 Análise de variância da população de milho Piranão VF1B no segundo ciclo de seleção do método Seleção IG. Anhembi e Piracicaba, 1999.

26 Análise de variância da população de milho ITA-PR no segundo ciclo de seleção do método Seleção IG. Anhembi e Piracicaba, 1999.

27 Análise de variância da população de milho Pichilingue no segundo ciclo de seleção do método Seleção IG. Anhembi e Piracicaba, 1999.

28 Análise de variância da população de milho Piranão VD2B no segundo ciclo de seleção do método Seleção IG. Anhembi e Piracicaba, 1999.

29 Análise de variância da população de milho HXL no primeiro ciclo de seleção do método Seleção IG. Anhembi e Piracicaba, 1999.

30 Análise de variância da população de milho Piranão VF1B no segundo ciclo de seleção do método Seleção $S_{1}$. Anhembi, 1999 e 2000

31 Análise de variância população de milho Pichilingue no segundo ciclo de seleção do método Seleção $S_{1}$. Anhembi, 1999 e 2000

32 Análise de variância da população de milho ITA-PR no segundo ciclo de seleção do método Seleção $\mathrm{S}_{1}$. Anhembi, 1999 e 2000.

33 Análise de variância da população de milho HXL no primeiro ciclo de seleção do método Seleção $S_{1}$. Anhembi, 1999 e 2000.

34 Análise de variância da população de milho ESALQ-PR1 no segundo ciclo de seleção do método Seleção $S_{1}$. Anhembi, 1999 e 2000.

35 Análise de variância da população de milho Piranão VD2B no segundo ciclo de seleção do método Seleção $S_{1}$. Anhembi, 1999 e 2000

36 Análise de variância conjunta da população de milho HXL no primeiro ciclo de seleção do método Seleção IG. Anhembi e Piracicaba, 1999. 
37 Análise de variância conjunta da população de milho ITA-PR no segundo ciclo de seleção do método Seleção IG. Anhembi e Piracicaba, 1999.

38 Análise de variância conjunta da população de milho Pichilingue no segundo ciclo de seleção do método Seleção IG. Anhembi e Piracicaba, 1999.

39 Análise de variância conjunta da população de milho Piranão VF1B no segundo ciclo de seleção do método Seleção IG. Anhembi e Piracicaba, 1999

40 Análise de variância conjunta da população de milho Piranão VF1B-P no segundo ciclo de seleção do método Seleção IG. Anhembi e Piracicaba, 1999

41 Análise de variância conjunta da população de milho Piranão VD2B no segundo ciclo de seleção do método Seleção IG. Anhembi e Piracicaba (SP), 1999.

42 Análise de variância conjunta da população de milho HXI no segundo ciclo de seleção do método Seleção $S_{1}$. Anhembi, 1999 e 2000.

43 Análise de variância conjunta da população de milho ITA-PR no segundo ciclo de seleção do método Seleção $S_{1}$. Anhembi, 1999 e 2000

44 Análise de variância conjunta da população de milho Pichilingue no segundo ciclo de seleção do método Seleção $S_{1}$. Anhembi, 1999 e 2000 .

45 Análise de variância conjunta da população de milho Piranão VF1B no segundo ciclo de seleção do método Seleção $S_{1}$. Anhembi, 1999 e 2000.........

46 Análise de variância conjunta da população de milho Piranão VD2B no segundo ciclo de seleção do método Seleção $S_{1}$. Anhembi, 1999 e 2000.

47 Análise de variância conjunta da população de milho ESALQ-PR1 no segundo ciclo de seleção do método Seleção $S_{1}$. Anhembi, 1999 e 2000. 


\title{
SELEÇÃo PARA PROLIFICIDADE EM POPULAÇÕES DE MILHO (Zea mays L.)
}

\author{
Autora: ANDRÉA PIZAIA \\ Orientador: Prof. Dr. JOSÉ BRANCO DE MIRANDA FILHO
}

\section{RESUMO}

A prolificidade ou a presença de duas ou mais espigas por planta, é um dos principais componentes de produção do milho. Confere alta estabilidade de produção e maior eficiência na utilização de nutrientes pelo aumento da força de dreno nas plantas. O objetivo do presente trabalho foi avaliar a eficiência de dois métodos de seleção recorrente intrapopulacional para a prolificidade e suas relações com a produção de grãos, em seis populações de polinização aberta: PIRANÃO VD2B, PIRANÃO VF1B, PIRANÃO VF1B-P, ITA-PR, PICHILINGUE e ESALQ-PR1, e estudar as características genéticas da prolificidade. As populações foram submetidas a dois métodos: a) Seleção $S_{1}$, baseado no desenvolvimento de progênies $S_{1}$ com a autofecundação das segundas espigas de plantas prolíficas e b) Seleção IG baseado no desenvolvimento de progênies de irmãos germanos através de cruzamentos biparentais utilizando as segundas espigas de plantas prolíficas. No método Seleção $S_{1}$ as progênies derivadas da seleção fenotípica utilizadas na recombinação, foram selecionadas com base em índices de espiga de plantas individuais. No método Seleção IG, após a seleção fenotípica de plantas individuais utilizadas no cruzamento biparental, as progênies utilizadas na recombinação foram selecionadas com base nos experimentos com repetições. Foram realizados dois ciclos de seleção e após cada ciclo, as progênies obtidas foram avaliadas em 
experimentos com repetições e o ganho genético e os parâmetros genéticos foram calculados. Apesar da avaliação das características do método Seleção $S_{1}$ ter sido mascarado pelos efeitos da endogamia, pode-se inferir que os dois métodos foram eficientes no aumento da prolificidade nas populações avaliadas. Contudo, o método Seleção IG, por evolver tanto a seleção massal, quanto o teste de progênies, parece ser mais efetivo para o aumento da prolificidade em populações de potencial prolífico inicial reduzido. A população PIRANÃo VD2B apresentou ganhos genéticos negativos com o método Seleção $S_{1}$. $O$ ganho genético realizado no primeiro ciclo com a seleção para a prolificidade na média das populações foi de $10,58 \%$ no método Seleção IG e de $-1,37 \%$ no método Seleção $S_{1}$. A herdabilidade e a variância genética da prolificidade foi maior no método Seleção $S_{1}$ do que no método Seleção IG. $O$ inverso ocorreu com a produção de espigas. A resposta correlacionada observada média da prolificidade na produção de espigas no primeiro ciclo foi de $6,27 \%$ no método Seleção IG. No segundo ciclo o aumento estimado médio da produção de espigas foi de $5,28 \%$ no método Seleção IG e de $9,62 \%$ no método Seleção $S_{1}$. A prolificidade apresentou menor depressão por endogamia que a produção de espigas, concordando com os resultados da literatura de que os efeitos de dominância na prolificidade são menores do que na produção de espigas. 


\title{
SELECTION FOR PROLIFICACY IN MAIZE
}

\author{
(Zea mays L.) POPULATIONS
}

\author{
Author: ANDRÉA PIZAIA \\ Adviser: Prof. JOSÉ BRANCO DE MIRANDA FILHO
}

\section{SUMMARY}

Prolificacy or the presence of two or more ears per plant is one of the main components of yield in maize. It provides high yield stability and higher efficiency in the utilization of nutrients by increasing the sink potential in the plant. The objective of this work was to evaluate the efficiency of two methods of intrapopulation recurrent selection for prolificacy and their relations with grain yield in six open-pollinated populations: PIRANÃO VD2B, PIRANÃO VF1B, PIRANÃO VF1B-P, ITA-PR, PICHILINGUE, and ESALQ-PR1; and add an study on the genetic characteristics of prolificacy. Populations were submitted to the methods designated as: a) $\mathbf{S}_{\mathbf{1}}$ Selection, based on the development of $S_{1}$ progenies by selfing the second ears of prolific plants; and b) IG Selection, based on the development of full-sib progenies through biparental crosses using the second ears of prolific plants. In the $S_{1}$ Selection method, the selected progenies used for recombination were derived from phenotypic selection based on ear index of individual plants. In the IG Selection method the selected progenies used for recombination were selected on the basis of progeny means from experiments with replications following phenotypic selection of individual plants used in the biparental crosses. Two cycles of selection were completed and in each cycle progenies were evaluated in experiments with replications and data were used for estimating genetic parameters including the expected genetic gain. In the $S_{1}$ Selection method the 
inbreeding effect shadowed the true expression of quantitative traits under evaluation but, in spite of that, overall results allowed to conclude that both methods were effective for increasing prolificacy in the populations under study. However, there was evidences that IG Selection is more effective for increasing prolificacy in populations with low initial expression for that trait because use full-sib progenies means and phenotypic selection. Population PIRANÃO VD2B, showed negative gain for prolificacy under $\mathrm{S}_{1}$ Selection. In the first cycle of selection the observed gains were $10,6 \%$ for IG Selection and $-1,7 \%$ for $S_{1}$ Selection, on the average of populations. Estimates of heritability and genetic variance for prolificacy were higher in the experiments of $S_{1}$ progenies as compared to full-sib progenies; the reverse was observed for yield. The correlated response on yield after selection for prolificacy under IG Selection was $6,27 \%$ on the average. In the second cycle the average gains were $5,28 \%$ and $9,62 \%$ in IG Selection and $S_{1}$ Selection, respectively. Inbreeding depression was lower for prolificacy than for yield in agreement with other reports that dominance effects are lower for prolificacy than for yield. 


\section{INTRODUÇÃO}

O homem tem praticado seleção para o aumento da adaptação e da produtividade do milho por milhares de anos. As formas ancestrais do milho pareciam com plantas daninhas e a transição destas formas para as espécies cultivadas requereu muitos anos de esforço pelos primeiros melhoristas. Apesar de utilizarem métodos primitivos, esta seleção, juntamente com a seleção natural, deu origem a cerca de 250 raças e milhares de variedades descritas.

Dentre as inúmeras modificações que se sucederam dos tipos primitivos até os tipos modernos atuais, está a presença de somente uma ou duas espigas por planta. A seleção para somente uma espiga por planta, levou ao aumento da dominância apical ou pela efetiva fixação dos alelos para a expressão de somente uma espiga ou indiretamente alterando o balanço dos reguladores de crescimento nas inflorescências masculina e feminina (Hallauer, 1974). O resultado desta seleção é que as plantas de milho atuais, apesar de possuírem de sete a oito gemas axilares com potencial de se desenvolverem em espigas, possuem apenas uma ou duas espigas funcionais por planta.

Contudo, a prolificidade ou a capacidade das plantas apresentarem duas ou mais espigas por planta, é um dos principais caracteres relacionados com a produção de grãos, devido ao aumento da "força de dreno", representado pelo aumento no número de espigas, grãos e tamanho dos grãos nas plantas.

A prolificidade apresenta grande importância no melhoramento do milho devido aos seguintes fatores: 1) em geral, apresenta alta correlação com a produtividade, respondendo tanto à seleção direta quanto à indireta;2) confere estabilidade de produção 
em diversos ambientes; 3) aumenta a eficiência das plantas na utilização dos nutrientes; e 4) apresenta facilidade de seleção.

O potencial da prolificidade para o aumento e a estabilidade da produção de grãos no milho aumentou o interesse no desenvolvimento de populações, híbridos e linhagens com maior tendência prolífica. $O$ trabalho pioneiro com a seleção para a prolificidade foi de Lonnquist (1967), que demonstrou a maior eficiência da seleção indireta para a produção de grãos através da prolificidade. A partir de então muitos outros trabalhos analisaram a influência da prolificidade na produção de grãos e a eficiência da seleção para a característica.

Apesar da importância da prolificidade no melhoramento do milho, existe carência de informações sobre os germoplasmas disponiveis no Brasil em relação ao potencial de utilização da prolificidade no melhoramento do milho para o aumento e a estabilidade da produção de grãos. A maior parte dos trabalhos de pesquisa estudam a prolificidade como uma característica secundária.

O objetivo do presente trabalho é analisar a eficiência de dois métodos intrapopulacionais na seleção para a prolificidade e suas relações com a produção de grãos. Ao mesmo tempo, pretende-se estudar a estrutura genética de populações de polinização aberta com relação à prolificidade e outros caracteres quantitativos. 


\section{REVISÃO DE LITERATURA}

\subsection{Aspectos gerais}

O milho (Zea mays L.) é uma espécie extremamente politípica, caracterizada por uma grande quantidade de variabilidade genética que se expressa em suas cerca de 250 raças descritas. Certamente por seleção natural, o milho desenvolveu tipos adaptados a climas específicos. Existem tipos que florescem com cerca de 30 dias até variedades que demoram um ano para florescer, mesmo em condições de adaptação (Paterniani, 1984). Existem tipos que se adaptam desde o nível do mar até altitudes acima de 3.800 metros, desde $58^{\circ}$ de latitude norte até $40^{\circ}$ de latitude sul e sobrevive em condições pluviométricas desde $250 \mathrm{~mm}$ até $10.000 \mathrm{~mm}$ (Hallauer \& Miranda Filho, 1988).

A maioria dos cultivares modernos de milho apresentam uma única espiga (inflorescência feminina) em planta de um único colmo, em contraposição aos tipos primitivos que apresentam muitas espigas e, não raro, muitos perfilhos (Brown, 1965). A razão desta situação atual é a forte pressão de seleção que foi praticada, tanto pelo homem primitivo como pelos melhoristas modernos, no sentido de diminuir o número $\mathrm{e}$ aumentar o tamanho da espiga (Hallauer \& Troyer, 1972). Existem relatos de variedade primitivas que produzem até 18 espigas por planta, as quais logicamente são menores do que nos cultivares comuns. $O$ fato importante é que no germoplasma do milho existe potencial para desenvolver cultivares com mais de uma espiga. A espiga é meramente uma ramificação em função da diferenciação lateral da áxis principal e o milho é 
potencialmente uma planta com alta capacidade para ramificações deste tipo (Sass \& Loeffel, 1959; Brown, 1965).

\subsection{A prolificidade no milho}

\subsubsection{A morfologênese floral}

O desenvolvimento da parte aérea do milho passa por uma fase vegetativa antes dos sinais de iniciação do pendão. Durante a fase vegetativa, folhas já presentes no embrião crescem e novas folhas são formadas. Os nós inferiores do caule ( 7 a 8) normalmente tem uma gema axilar vegetativa. Estas gemas axilares desenvolvem-se em uma sucessão acrópeta, da base para o caule. Provavelmente, os meristemas laterais têm início na mesma taxa que os primórdios foliares do meristema apical e o estágio crítico para o desenvolvimento da espiga principal é um pouco antes da iniciação do meristema axilar que corresponde à iniciação do pendão (Lejeune \& Bernier, 1996). A iniciação das folhas e gemas axilares cessa guando tem início a formação do pendão, o que ocorre 2 a 3 semanas após a emergência. As gemas são transformadas em espigas em uma seqüência basípeta, ou seja, do ápice para a base. A iniciação da inflorescência terminal masculina precede o desenvolvimento floral dos ramos axilares em aproximadamente 7 dias (Tollenaar, 1977; Motto \& Moll, 1983). As inflorescências axilares, através de uma série de estágios de desenvolvimento, são transformadas em uma ou mais espigas funcionais. $O$ desenvolvimento floral começa na espiga superior $e$ progride basipetalmente para as gemas dos nós inferiores (Motto \&Moll, 1983).

Embora alguma diferenciação ocorra nos nós inferiores, o crescimento e desenvolvimento das gemas é controlado. Normalmente, somente as gemas localizadas nos nós superiores das plantas formam espigas funcionais. Portanto, embora ocorra a iniciação de várias espigas nas plantas de milho, somente uma ou duas desenvolvem-se até a maturidade em densidades comerciais. O número máximo de espigas é determinado pelo genótipo e pelo ambiente (Veit et al., 1993). 


\subsubsection{A ocorrência da dominância apical no milho}

A ocorrência da dominância apical no milho, ou seja, a supressão do desenvolvimento das espigas inferiores no caule pela espiga superior, tem sido descrita por muitos autores (Phillips, 1975; Sorrells et al., 1978; Motto \& Moll, 1983; Cline, 1997). Segundo Cline (1997), o processo de ocorrência da dominância apical e sua liberação, podem ser divididos em quatro estágios de desenvolvimento: a) formação do meristema lateral; b) inibição do crescimento da gema lateral; c) liberação da dominância apical seguido da decapitação, que pode ser promovido pela citocinina e inibido pela auxina; d) desenvolvimento do ramo lateral, que pode ser promovido pela auxina e giberelina.

Os resultados mostram que genótipos com diferente potencial prolífico tem um mecanismo de controle inerente que permite a produção de grãos somente nas espigas superiores (Harris et al., 1976; Motto \& Moll, 1983). O intervalo de tempo entre o florescimento da segunda e da primeira espiga tem grande influência sobre a formação das segundas espigas. Portanto, tem-se considerado que o mecanismo de repressão pelas espigas apicais é uma seqüência dependente do tempo, mediado pela difusão de reguladores de crescimento (Phillips, 1975; Sorrells et al., 1978; Motto \& Moll, 1983). Estes autores indicaram que o AIA (ácido indol acético), ácido giberélico e possivelmente outros hormônios interagem num modo de inibição dependente do tempo sobre o desenvolvimento das espigas inferiores.

O componente primário do sinal correlativo inibitório é a síntese de auxinas na região superior dos ramos secundários, provavelmente nas folhas novas em expansão, $\mathrm{e}$ o seu transporte para as regiões inferiores do caule. Isto porque as auxinas, impedem a síntese de DNA e a divisão celular nas espigas inferiores. Uma das teorias é que ocorre um mecanismo de transporte de hormônios, os quais tem influência direta sobre o transporte do floema nas espigas inferiores, ou um efeito indireto sobre o transporte pela ativação da atividade local de dreno na espiga superior (Sorrells et al.,1978). 
Por outro lado, o período entre a fertilização das espigas sucessivas é aparentemente crítico em determinar a extensão do desenvolvimento basípeto. Este intervalo poderia permitir um rápido aumento nos níveis de auxina das espigas superiores fecundadas que seria translocado para as regiões inferiores no colmo e promover a formação de um inibidor ou um metabólito direto para as espigas superiores. O precoce estabelecimento do transporte do metabólito para o dreno maior, poderia fornecer à espiga uma vantagem distinta sobre as espigas secundárias e possivelmente retardar o seu desenvolvimento. A variação no número de espigas entre plantas de um mesmo genótipo poderia ser explicada pela flutuação nos níveis hormonais endógeno em resposta às diferenças microambientais que cada planta individual está sujeita (Harris et al., 1976).

A descoberta de que as giberelinas são também sintetizadas nas folhas novas e são transportadas para as regiões inferiores do caule, sugere que esta classe de hormônios tem uma função regulatória primária na inibição correlativa das gemas inferiores (Phillips, 1975; Sorrells et al., 1978). O ácido giberélico age com o AIA estimulando a translocação de metabólitos e a dominância apical, inibindo o desenvolvimento das espigas inferiores. A citocinina tem um papel importante na liberação dos ramos laterais da dominância apical, devido ao aumento da sua concentração precedendo a elongação dos ramos laterais em ervilha (Li et al., 1995). O efeito de uma auxina sobre a concentração das citocininas demonstrou o efeito do transporte polar basípeto da auxina na dominância apical. Estes resultados sugeriram a interação mútua entre o sistema de transporte basipolar de auxina e as citocininas produzidas nas raízes e transportadas via xilema pelo caule das plantas de ervilha.

A inibição correlativa envolve a deficiência nas gemas laterais de alguns fatores essenciais para o seu desenvolvimento, podendo ser estes fatores hormonais ou nutricionais. A falta de estímulo hormonal, particularmente citocininas, pode em alguns casos ser o resultado da incapacidade para sua síntese ou utilização, mas aparentemente, as gemas inibidas não apresentam uma quantidade suficiente de citocininas e substâncias nutricionais. Alguns metabólitos e citocininas também são mobilizados pela aplicação 
localizada de certos hormônios, principalmente auxinas, que podem induzir o transporte a longa distância dos metabólitos. Este fenômeno é denominado de transporte hormônio dirigido (THD). Portanto, as giberelinas e citocininas atuam sinergisticamente com as auxinas no THD.

Damptey (1982) sugeriu que a auxina e provavelmente o ácido giberélico, sintetizado no pendão, são translocados para as inflorescências axilares inferiores, afetando sua dominância. A deficiência de água resultou numa acumulação de ácido abscísico, afetando a síntese daqueles hormônios ou sua trasladação para as inflorescências axilares, estimulando o crescimento das inflorescências laterais. Com relação aos efeitos ambientais sobre a dominância apical, é provável que os efeitos do nível dos elementos minerais sobre a dominância são mediados pelos níveis de hormônios e nutrientes nas plantas. $O$ fotoperíodo afeta a dominância, onde dias curtos podem reduzir e dias longos podem aumentar a inibição correlativa (Motto \& Moll, 1983).

\subsection{As condições ambientais e a expressão da prolificidade}

\subsubsection{Efeito do nitrogênio}

A freqüência de plantas com duas espigas no milho aumenta quando a emergência dos estigmas da espiga apical e subapical são sincronizadas, com uma diferença de até 24 horas uma da outra (Harris et al., 1976; Camberato et al., 1989). O baixo suprimento de nitrogênio $(N)$ não restringe a elongação da espiga apical, mas reduz a taxa de elongação da espiga subapical e a sincronia entre as duas espigas. E a elongação da espiga subapical foi demonstrado ser paralela à elongação da espiga apical sob condições não estressantes. Isto indica que a taxa de crescimento das duas espigas deve ser responsável pelas diferenças na freqüência de plantas com sincronia.

Camberato et al. (1989) encontraram dominância apical para o suprimento de $\mathrm{N}$, regulando a elongação da espiga subapical, devido ao suprimento insuficiente de $\mathrm{N}$ 
em híbridos prolíficos. Os autores observaram que a não sincronia de florescimento entre as duas espigas é decorrente da competição entre elas por quantidades insuficientes de nutrientes para o crescimento de ambas as espigas.

O sincronia entre o florescimento masculino e da segunda espiga, também tem influência sobre o nível de prolificidade das plantas, o que é altamente influenciado pelas condições ambientais. Jacobs \& Pearson (1991) observaram ausência de sincronia somente no florescimento da segunda espiga com o pendão, mas não na primeira espiga, apesar do estresse imposto pela falta de $\mathrm{N}$ e aumento da densidade populacional ter reduzido a iniciação do florescimento e as taxas de elongação das espigas. Os autores concluíram que há uma hierarquia no desenvolvimento das espigas e que o estresse induz mudanças no rendimento por planta o que é devido à mudanças no número de espiguetas formadas e no número destas que se desenvolvem em grãos; e em segundo do número de espigas por planta e do peso dos grãos.

Brotslow et al. (1988), não observaram efeito do número de espigas e do rendimento sobre o vigor radicular e sobre o vigor do colmo em populações prolíficas de milho. Observaram que as plantas com duas espigas e com maior produção de grãos, apresentaram estreita sincronia entre a antese e o florescimento feminino e maior altura de espigas que as plantas com uma espiga.

Por outro lado, os genótipos prolíficos são capazes de extrair mais $\mathrm{N}$ da solução do solo do que os não prolíficos e são mais eficientes na utilização do $\mathrm{N}$ (Casnoff, 1984). Durieux et al. (1993) observaram aumento no peso da espiga apical e subapical de híbridos prolíficos em reposta ao aumento da taxa de $\mathrm{N}$. No híbrido com alto potencial prolífico, ocorreu uma grande resposta à aplicação de $\mathrm{N}$ através do aumento do peso da primeira e da segunda espiga. Em ordem de importância, os fatores que contribuem para o aumento do rendimento em resposta ao $\mathrm{N}$ são: aumento no número espigas subapicais, aumento no peso da espiga apical e um aumento no peso da espiga subapical. 


\subsubsection{Efeito da deficiência hídrica}

O desenvolvimento da espiga subapical é mais sensivel ao estresse hídrico do que a espiga apical (Sorrells et al., 1979). A exposição das plantas de milho à seca durante o início do desenvolvimento do embrião e durante o florescimento, resulta na inibição da formação das flores femininas e um retardamento na emergência dos estigmas. Isto acarreta altas reduções na produção de grãos.

O tipo de efeito que o estresse causa na planta é dependente do estágio do desenvolvimento da planta de sua ocorrência (Motto \& Moll, 1983). O estresse hídrico ocorrendo entre o florescimento masculino e o feminino reduz o número de grãos por planta. Isto ocorre devido ao atraso no florescimento feminino em relação à antese quando as plantas estão estressadas, redundando numa fraca fertilização. Quando o estresse hídrico ocorre antes do florescimento feminino e a polinização, ocorre a redução do número de espigas por planta.

Tem sido observado que o aumento do estresse hídrico reduz o número de segundas espigas nas plantas prolíficas. Undersander (1987), verificando a resposta de híbridos de milho ao estresse hídrico, observou um aumento no número de espigas por planta com o aumento da evapotranspiração sazonal, e esta resposta não variou significativamente entre os híbridos. $O$ autor verificou uma redução no número de grãos por planta com o estresse hídrico antes e durante o florescimento masculino e feminino. Biasutti \& Peiretti (1992) observaram que a tolerância à seca poderia ser melhorada selecionando plantas prolíficas com menor intervalo de florescimento, maior número de grãos/fileira e reduzida senescência foliar. Observaram que a produção de grãos sobre estresse foi influenciado pelo número de folhas, altura da espiga, maturidade da camada preta, senescência da folha da espiga, prolificidade, intervalo entre o florescimento masculino e o feminino, altura da planta e número de grãos/fileira. Guei e Wassom (1992) observaram que a data do florescimento feminino, intervalo entre a antese e o florescimento feminino e o número de espiga por planta correlacionaram-se melhor com a produção de grãos em condições estressantes de deficiência hídrica, do que em 
ambientes não estressantes. Estas características poderiam ser utilizadas para a seleção para a resistência à seca.

\subsubsection{Efeito da densidade populacional}

Numerosos estudos sobre os efeitos de diferentes densidades populacionais revelaram que a diminuição da área de solo, explorada por cada planta pelo aumento na densidade, tem um efeito negativo sobre o número e o tamanho das espigas por planta de híbridos com múltiplas espigas (Motto \& Moll, 1983). Seria a redução da luminosidade o responsável pela redução no número de espigas e na produção por planta. $\mathrm{O}$ trabalho de Teyker et al. (1991) com a desfolha das folhas inferiores do milho, demonstrou que estas folhas são as responsáveis pelo suprimento de carbohidratos para as raizes após a antese, mantendo a absorção de nitrogênio após este período. Portanto, é provável que a alta densidade populacional inibe a fotossíntese nas folhas inferiores e, consequentemente, o transporte de carbohidratos para o sistema radicular, reduzindo o fornecimento de nutrientes para as segundas espigas.

Normalmente o aumento da densidade populacional atrasa o florescimento feminino, fazendo com que não haja coincidência entre o florescimento masculino e feminino (Jacobs \& Pearson, 1991). Isto faz com que ocorra a redução do número de grãos por planta e do número de espigas por planta. Contudo, os genótipos prolíficos, apesar de reduzirem o número de plantas com duas espigas, tem uma maior porcentagem de plantas com uma espiga em altas densidades e o intervalo entre o florescimento masculino e da primeira espiga é menor nestes genótipos. Isto resulta em maior número de grãos por planta e em maior produtividade que os genótipos não prolíficos.

Thomison \& Jordan (1995), estudando o efeito da densidade populacional sobre o híbridos de milho que diferiam no hábito de crescimento da espiga, observaram que o híbrido prolífico apresentou maior produtividade em ano com deficiência hídrica do que os outros híbridos, contudo apresentou alta suscetibilidade ao acamamento o que limita sua utilização em larga escala. Observaram ausência de interação híbrido x densidade 
populacional, sugerindo que as diferenças em prolificidade e hábito de crescimento da espiga tem pouca importância na determinação da população ideal de plantas.

Os híbridos comerciais modernos suportam mais o estresse da alta densidade do que os híbridos antigos, o que está relacionado com o maior número de espigas por planta destes materiais. Cox (1996), comparando o desempenho produtivo e fisiológico de híbridos de milho em diferentes densidades populacionais, observou que os híbridos mais modernos apresentaram máximo rendimento de matéria seca à uma densidade de 9 plantas $/ \mathrm{m}^{2}$ e máximo rendimento com 6,75 plantas $/ \mathrm{m}^{2}$. O trabalho mostrou que os híbridos prolíficos (ou com número de espigas flexível) e com tolerância à seca apresentaram uma resposta mais linear no aumento da matéria seca e na produção de grãos com o aumento da densidade nos anos de estudo. Ao contrário, os híbridos não tolerantes à seca, tiveram uma redução acentuada no número de grãos por planta e um aumento no número de plantas sem espigas ("barrenness") em altas densidades em anos secos.

Tollenaar et al. (1992) analisaram a resposta de várias gerações de híbridos à diferentes densidades populacionais e observaram que o maior número de grãos nos híbridos recentes foi associado com menor número de plantas sem espigas e no aumento da prolificidade. A média da relação do número de grãos por unidade de crescimento à densidade de 13 plantas / $\mathrm{m}^{2}$ foi de $171 \pm 27$ grãos / grama / dia nos híbridos recentes $\mathrm{e}$ de $116 \pm 19$ grãos / grama / dia nos híbridos antigos. Morello et al. (1994) realizaram um ciclo de seleção massal para prolificidade na população 'CMS-39' em três densidades populacionais. Observaram que as densidades populacionais afetaram o número de espigas por planta mas não a produtividade das populações melhoradas. Concluíram que a seleção para a prolificidade na densidade máxima de 42.000 plantas/ha proporcionaria os melhores resultados. Buren et al. (1974) indicaram que genótipos tolerantes à alta densidade populacional poderiam ser caracterizados através do rápido aparecimento da barba, coincidência entre o florescimento feminino e o masculino, crescimento rápido da primeira espiga, prolificidade, reduzido tamanho do pendão e eficiente produção de grãos por unidade de área. 
Contudo, Mariani \& Desiderio (1974) observaram a predominância da variância aditiva para os caracteres relacionados com a produção, incluindo a prolificidade, em baixas densidades populacionais e menor variância aditiva em altas densidades populacionais nos mesmos caracteres. Em ambas as densidades, a produção de grãos e ENWI (um índice composto pelo peso de cada espiga) apresentaram baixa e negativa correlação. Portanto, as repostas da prolificidade em distintos ambientes, como diversas densidades populacionais, depende do material estudado e das condições ambientais do local de estudo.

\subsubsection{Eficiência da utilização do nitrogênio}

A produção de grãos de um dado genótipo de milho é dependente de inúmeros fatores, como do tamanho do "dreno" por planta, do suprimento de fotossintetatos, da partição total da matéria seca para o grão e do eficiente uso do N. O tamanho do dreno pode ser definido como o tamanho do grão, número de grãos por planta e do número de espigas por planta (Anderson et al., 1984). O suprimento de $\mathrm{N}$ pode afetar o tamanho do dreno de certos genótipos pelo aumento do número de espigas por planta.

Vários trabalhos demonstraram que a influência do número de espigas sobre a acumulação de matéria seca e a sua partição depende do genótipo estudado. A remobilização do $\mathrm{N}$ do caule e folhas possivelmente é uma importante fonte de $\mathrm{N}$ no enchimento do grão, e a variação na remobilização é característico de cada genótipo e do ambiente. Anderson et al. (1984) observaram a importância da remobilização durante o enchimento dos grãos. $\mathrm{O} \mathrm{N}$ é deslocado das folhas e colmo imediatamente depois do florescimento feminino, o que é correspondente ao período de maior aumento no conteúdo de $\mathrm{N}$ na espiga. Apesar dos resultados indicarem que a quantidade de matéria seca e a acumulação do $\mathrm{N}$ não são associados ao tamanho do dreno, a partição da matéria seca e do conteúdo de $\mathrm{N}$ foi significativamente afetado pelo tamanho do dreno. Genótipos com maior número de espigas foram mais eficientes em partilhar a matéria seca e o $\mathrm{N}$ para o grão e utilizar eficientemente o $\mathrm{N}$ (peso grãos/N da planta). 
$\mathrm{O}$ conteúdo de $\mathrm{N}$ do grão é derivado do $\mathrm{N}$ remobilizado das folhas, colmo $\mathrm{e}$ raízes $\left(\mathrm{N}_{\mathrm{r}}\right)$ e também da absorção de $\mathrm{N}$ após a antese $\left(\mathrm{N}_{\mathrm{a}}\right)$. Os híbridos de milho com diferente potencial prolífico diferem nesta característica (Pan et al., 1986).

Estudos sugerem que a partição do carbono para o desenvolvimento do grão tem prioridade sobre o carbono necessário para as raízes. Existe uma relação inversa entre o número de espigas por planta e a absorção de $\mathrm{N}$ após a antese. Isto é decorrente da redução do carbono para as partes vegetativas e consequentemente leva a redução da absorção de $\mathrm{N}$. Híbridos com maior número de espigas por planta exibiram baixa absorção de $\mathrm{N}$ após a antese e alta remobilização de $\mathrm{N}$, sendo que este é estimulado pelo desenvolvimento da segunda espiga. É a fotossintese que ocorre após a antese que sustenta o enchimento da segunda espiga porque o crescimento da primeira espiga é prioritário em caso de limitação de umidade (Pan et al., 1995).

Durieux (1990) observou que os híbridos prolificos translocaram mais matéria seca e $\mathrm{N}$ do colmo e folhas para a espiga durante o crescimento reprodutivo. A eficiência de utilização de $\mathrm{N}$ foi maior nestes híbridos (relação peso de grãos/conteúdo total de $\mathrm{N}$ ), apesar do conteúdo total de $\mathrm{N}$ não ter sido maior. A plantas prolíficas apresentaram uma redução na atividade de absorção de nutrientes das raízes depois da antese, ratificando a hipótese da limitação de energia para as raízes das plantas prolíficas. A taxa de absorção de $\mathrm{N}$ e potássio foi menor e de cálcio e magnésio foi maior nas plantas prolíficas após a antese.

Kamprath et al. (1982), comparando a resposta à aplicação de $\mathrm{N}$ em populações melhoradas via seleção intrapopulacional (familias de meios irmãos) e interpopulacional (recorrente recíproca), observaram que a seleção recorrente recíproca resultou numa população com maior eficiência na utilização do $\mathrm{N}$ do que a população desenvolvida pelo método intrapopulacional. Isto foi relacionado ao potencial de desenvolvimento de duas espigas por planta na população oriunda da seleção recíproca.

Chanh Ta et al. (1993) demonstraram que ao menos sete proteínas funcionam como formas de armazenamento temporário de $\mathrm{N}$ no colmo. Estas proteínas são 
degradadas durante as três semanas após a antese para fornecer $\mathrm{N}$ orgânico para o desenvolvimento da espiga.

Por outro lado, Teyker et al. (1991), estudando os efeitos da retirada das folhas inferiores em híbridos prolificos, observaram que a retirada das 3 últimas folhas durante e depois da antese, teve um maior efeito redutor sobre a segunda espiga do que sobre a primeira. Genótipos com maior capacidade de acumular $\mathrm{N}$ nas folhas inferiores na antese em resposta à aplicação de $\mathrm{N}$, foram mais eficientes em absorver $\mathrm{N}$ durante $\mathrm{o}$ enchimento do grão e mantiveram maior atividade fotossintética durante o crescimento reprodutivo. Isto sugere que as folhas inferiores suprem de carbohidratos o sistema radicular, mantendo a absorção de nutrientes após a antese e que existe variabilidade ente os híbridos prolíficos nesta função.

\subsection{A herança da prolificidade}

A prolificidade no milho é classificada como uma característica de alta herdabilidade. Hallauer \& Miranda Filho (1988) obtiveram, na média de 39 estimativas, um coeficiente de herdabilidade de $39 \%$, e as variâncias aditiva e dominante foram de $45,9 \times 10^{-3}$ e $11,8 \times 10^{-3}$, respectivamente, indicando a predominância da ação gênica aditiva na expressão do caráter.

Soares Filho (1987) estimou coeficientes de herdabilidade para médias de progênies, em dois anos, da ordem de $61,6 \%$ e 29,1\% para Piranão VD2B e de 25,0\% e $45,8 \%$ para Piranão VF1B; as estimativas da variância aditiva foram de $37,5 \times 10^{-3} \mathrm{e}$ $4,11 \times 10^{-3}$ para Piranão VD2B e de $21,3 \times 10^{-3}$ e $20,9 \times 10^{-3}$ para Piranão VF1B. Para Piranão VD2B a diferença de expressão na variabilidade foi atribuída a diferentes efeitos ambientais nos dois anos. Miranda Filho \& Andrade (2000) relataram herdabilidade de $16,3 \%$ e 40,9\% para indivíduos e médias de progênies, respectivamente, na população ESALQ-PB $^{1}$; a estimativa da variância aditiva foi de $17,7 \times 10^{-3}$.

Hallauer (1974) obteve uma estimativa média de $24,2 \%$ no cruzamento entre linhagens de milho com diferente número de espigas por planta, testadas em diferentes 
densidades populacionais. Guei e Wassom (1992) observaram estimativas de herdabilidade de $12 \%$ em condições estressantes de deficiência hídrica e de 3,8 e $7 \%$ em condições não estressantes em dois compostos de milho.

Muitos trabalhos mostraram que a expressão da prolificidade tem herança predominantemente aditiva (Sorrells et al., 1979; Laible \& Dirks, 1968). Stuber et al. (1966) observaram que a variância aditiva é maior que a variância de dominância para prolificidade e a variância epistática não foi detectada. Laible \& Dirks (1968) observaram que a magnitude da variância não aditiva foi próxima a zero no estudo de diversas gerações de várias combinações híbridas. Observaram valores de variância aditiva de $16,8 \times 10^{-3}$ a $115,4 \times 10^{-3}$ para número de espigas.

Subandi \& Compton (1974) observaram relação entre a estimativa de dominância pela variância genética aditiva do número de espigas por planta de $0,24 \mathrm{em}$ plantios em baixa densidade e 0,29 em plantios de alta densidade, sugerindo que a maioria dos locus que controlam a característica possuem dominância parcial a completa. Para produção de espigas os autores estimaram variância aditiva de 171,3 em altas densidades populacionais. Hallauer \& Miranda Filho (1988) observaram variância aditiva de 469,1 gramas por planta ${ }^{2}$ para a produção de grãos na média de 99 estimativas.

Sorrells et al. (1979), trabalhando com linhagens, e gerações $F_{1}, F_{2}$ e retrocruzamentos, observaram que os efeitos aditivos foram altamente significantes para o número de espigas e um índice do peso de múltiplas espigas. A análise genética de dois pares de linhagens indicaram que um único loco ou um grupo de locus ligados responderam pela maior parte da variação no número de espigas.

A produção múltipla de espigas ajusta-se à descrição de um caráter umbral, pois os efeitos genéticos e de ambiente a ela associados tem distribuição contínua enquanto que a sua expressão fenotípica tem distribuição discreta (Hallauer, 1974; Harris et al., 1976). Como a expressão da prolificidade é altamente dependente do ambiente, a herdabilidade apresenta-se inconsistente sob condições ambientais diferenciadas, com estimativas que podem variar de $0 \%$ (Hallauer, 1974) a 100\% (Hallauer \& Troyer, 
1972). De fato, o número de espigas por planta resulta da combinação de forças genéticas e de ambiente dentro de um período de seis semanas que antecede ao florescimento; se a referida combinação for desfavorável neste período, as plantas terão espigas únicas, mesmo que condições ótimas à produção de grãos ocorra após este período crítico (Hallauer \& Miranda Filho, 1988).

Hallauer (1974) observou que a prolificidade é uma característica poligênica, mas com distribuição descontínua, ou seja, a herança é quantitativa mas a expressão é qualitativa. Concluiu que a utilização de procedimentos quantitativos parecia ser apropriado para o aumento do nível de prolificidade.

Contudo, trabalhos recentes indicam que a característica é governada por um ou poucos genes (Harris, et al., 1976; Sorrells et al., 1979; Maita \& Coors, 1996). A maior parte dos estudos sobre a herança da prolificidade no milho sugere que poucos genes de caráter recessivo controlam o caráter (Duvick, 1974, Hallauer 1974).

Harris et al. (1976) observou que o forte potencial prolífico foi devido à condição genética recessiva e que as diferenças genotípicas entre os híbridos de uma e duas espigas deve envolver 2 locus de grande efeito. Respostas genotípicas à manipulação da polinização não forneceram evidências para se rejeitar o modelo de herança qualitativa, em que o desenvolvimento das segundas espigas não sincronizadas é regulado pela difusão de hormônios que são produzidos pelas espigas superiores antes da antese.

Contudo, Moll et al. (1981) encontraram evidências de que a segregação de plantas com espigas sincronizadas e assincronizadas é controlada por mais que um simples locus. Mas, indicaram que a segregação do desenvolvimento das segundas espigas entre plantas com emissão sincronizada da barba deve envolver um único locus de grande efeito. Portanto, a ausência de sincronia, que determina a prolificidade e é regulada pelo nível de estresse a que as plantas estão sujeitas, envolve um grande número de processos que determinam a penetrância do gene de grande efeito. 
O aumento da taxa de homozigose (ou diminuição da heterozigose) não tem um efeito perfeitamente previsível sobre a prolificidade. Sing et al. (1967) detectaram a diminuição do número de espigas em duas populações sob endogamia. Good e Hallauer (1977) estudaram três sistemas e endogamia e verificaram diminuição do número de espigas em uma população e aumento em outra. Depois de oito gerações de autofecundação, o aumento do número de espigas na população BSSS foi da ordem de $30 \%$. Nass (1992) detectou diminuição do número de espigas da ordem de $33 \%$ e $24 \%$ nas populações semi-exóticas ESALQ-PB ${ }^{1} \times$ ENTRALAÇADO e ESALQ-PB $^{1} x$ CRAVO, respectivamente. O grande efeito da endogamia sobre o número de espigas pode ter sido conseqüência de genes deletérios recessivos que afetam fortemente a adaptabilidade das populações.

A prolificidade pode ser melhorada por métodos típicos qualitativos, como o retrocruzamento. Duvick (1974) mostrou ser possível transferir em parte a característica através do retrocruzamento. Contudo, as linhagens obtidas apresentarem menor produtividade e maior acamamento e apresentaram plantas significativamente mais baixas e sem espigas em altas densidades populacionais.

\subsection{A correlação da prolificidade com a produção de grãos}

A prolificidade é associada com alto rendimento de grãos no milho devido à sua alta correlação com a produção (Lonnquist, 1967; Laibe \& Dirks, 1968; Hallauer, 1974; Mareck \& Gardner, 1979; Souza Júnior et al., 1985; Singh et al., 1986; Coors \& Mardones, 1989; Maita \& Coors, 1996).

Robinson et al. (1951) observaram que o número de espigas por planta, entre diversas características analisadas, obteve a maior correlação genética positiva com a produção de grãos. $(0,819)$, na análise combinada de três populações de milho prolífico. Souza Júnior et al. (1985) obtiveram coeficiente de correlação genética de 0,941 entre a prolificidade e a produção de grãos e de $-0,648$ entre a prolificidade o número de ramificações no pendão em progênies de meios irmãos da população 'Suwan'. 
Correlações genéticas parciais indicaram que o efeito do tamanho do pendão sobre a produção de grãos ocorre diretamente através da prolificidade. Os autores obtiveram uma resposta correlacionada estimada para a produção de grãos de $16,6 \%$, selecionandose para a prolificidade. Hallauer \& Miranda Filho (1988) relataram correlação de 0,43 , na média de 16 estimativas. Coors \& Mardones (1989) observaram correlação de 0,90 na população Golden Glow. Collins et al. (1965), avaliando a performance de híbridos com duas espigas, observaram que estes apresentaram uma produção de grãos mais consistente do que os tipos de uma espiga, com as várias densidades populacionais testadas. Esta resposta ocorreu devido à capacidade dos híbridos de duas espigas se ajustarem às flutuações ambientais pela mudança no número de espigas produzidas.

Agrama (1996) realizou uma análise de trilha seqüencial de 5 componentes de rendimento e constatou que o número de espigas por planta teve o maior efeito direto sobre a produção de grãos. Concluiu que o número de grãos por planta, a prolificidade e o tamanho dos grãos servem como características potenciais para o melhoramento da produtividade.

Normalmente ocorre o declínio na herdabilidade da produção de grãos sob condições de estresse (Blum, 1988; Bolanos \& Edmeades, 1996). Em condições de estresse hídrico, a herdabilidade da produção de grãos normalmente é menor porque a variância genética diminui mais rapidamente do que a variância ambiental entre parcelas. Em contraste a herdabilidade do IAF (intervalo entre a antese e o florescimento feminino) e do número de espigas por planta tende a aumentar ou permanecer constante sob estresse (Bolaños \& Edmeades, 1996). Com o aumento do estresse, aumenta a dependência da produção sobre o número de espigas por planta e desta sobre o IAF. Isto porque o estresse hídrico aumenta $o$ intervalo entre o florescimento masculino e feminino, resultando em ausência de sincronia (Laffite \& Edmeades, 1995).

Bolaños \& Edmeades (1996) observaram que em ambiente sem deficiência hídrica, o número de espigas por planta respondeu por $24 \%$ da variação na produção, enquanto que em ambiente onde ocorreu estresse hídrico durante o florescimento, o número de espigas por planta respondeu por $59 \%$ da variação na produção. A seleção em 
condições de seca tem sido acompanhada por grande reduções na IAF nas populações do CIMYT.

Terrazas et al. (1995) observaram alta correlação entre produção e IAF e um índice de prolificidade, sugerindo que estas características podem ser usadas como indicadores de tolerância à seca de uma população. Isto ocorre porque, em condições de seca, os ganhos genéticos são mantidos principalmente com a seleção para IAF e número de espigas por planta nos quais a variância genética e a correlação com a produção aumentam, e em menor intensidade com a produção de grãos (Bolaños \& Edmeades, 1996).

Guei \& Wassom (1992) observaram que a data de florescimento feminino, o intervalo entre o florescimento masculino e feminino e o número de espigas por planta se correlacionaram melhor com a produção de grãos em condições de estresse do que em ambientes não estressantes. Estas características poderiam ser utilizadas para seleção à tolerância à seca nas populações estudadas.

Um dos grandes méritos da prolificidade é a tolerância que confere em ambientes estressantes, como por exemplo o estresse hídrico ou elevadas densidades populacionais, principalmente devido à redução do "barrenness". Russel (1968) observou que a vantagem dos híbridos de duas espigas estava na resistência destes híbridos ao "barrenness" em altas densidades populacionais. Prior \& Russel (1975) observaram que os híbridos prolíficos apresentaram um maior intervalo de densidade ótima do que os híbridos com uma espiga. Eles sugeriram que os híbridos prolíficos tem uma resposta melhor a altas densidades e/ou condições estressantes porque são mais resistentes ao "barrenness".

Tollenaar et al. (1992), investigando a formação da espiga e dos grãos em uma série de densidades e gerações de híbridos, observou que o melhoramento para a produção de grãos dos híbridos foi associado ao aumento no número de grãos por planta, o que é determinado pelo número de espigas por planta. $\mathrm{O}$ aumento da prolificidade levou a um menor nível de "barrenness" em altas densidades populacionais. Maita \& 
Coors (1996) observaram que o aumento da prolificidade com os ciclos de seleção, aumentou o rendimento em altas densidades populacionais.

Maita et al. (1995b), estudando a estabilidade fenotípica em 20 ambientes, observaram que a seleção para prolificidade aumentou a estabilidade estática e biológica da produção de grãos na população Golden Glow.

Otegui (1995), estudando a prolificidade nos híbridos argentinos, observou que a aborto das espiguetas da espiga apical diminuiu com o aumento da prolificidade e que os híbridos não prolíficos apresentaram uma maior variabilidade na proporção de espiguetas abortadas. Provavelmente, devido à maior influência ambiental sobre o florescimento feminino.

\subsection{A seleção recorrente e a prolificidade}

Muitos autores utilizaram a seleção massal para a seleção para a prolificidade com sucesso no aumento da produção de grãos (Lonnquist, 1967; Mareck \& Gardner, 1979; Paterniani, 1980a; Paterniani, 1980b; Segovia, 1983; Maita \& Coors, 1996). Isto ocorreu devido a elevada herdabilidade da prolificidade e à sua alta correlação com a produção de grãos nas populações estudadas.

A seleção massal é o mais antigo método de melhoramento do milho, na qual a unidade de seleção são os fenótipos de plantas individuais, sem o uso de repetições. $O$ método tem sido efetivo na fixação de algumas características, mas geralmente não é efetivo no melhoramento da produção de grãos devido à problemas experimentais, como ausência de controle ambiental, presença de interação genótipo $\mathrm{x}$ ambiente, ausência de controle parental e reduzida precisão experimental (Hallauer \& Miranda Filho, 1988).

A obtenção de altas correlações com produção e a alta herdabilidade da característica tem levado os melhoristas a optarem para a seleção indireta para produção de grãos por meio da seleção massal para prolificidade. Lonnquist (1967), foi o primeiro pesquisador a efetuar a seleção indireta para a produção de grãos. Realizando seleção 
massal para a prolificidade durante 5 gerações na variedade Hays Golden, observou ganho genético na produtividade de $6,28 \%$ por ciclo. Quatro gerações de seleção para prolificidade na variedade resultou num nível de produtividade correspondente a dez gerações de seleção para produção de grãos. Estes resultados mostraram que seleção indireta poderia ser mais efetiva se a característica secundária tem maior herdabilidade que a primária e a correlação genética entre as duas é alta.

Em uma publicação posterior, Maita \& Coors (1996), obtiveram um ganho de $1 \%$ por ciclo em 20 ciclos de seleção para prolificidade na mesma população avaliada por Lonnquist. A seleção para prolificidade mudou a produção de grãos em altas densidades populacionais. A resposta da população a altas densidades tornou-se mais linear e os últimos ciclos apresentaram maior produção em altas densidades do que os ciclos iniciais (Maita et al., 1995b). O trabalho evidenciou a efetividade de seleção para produção de grãos pela prolificidade e mostrou que a eficácia do método é influenciada por vários fatores, como a base genética, capacidade de controle da polinização e a heterogeneidade do ambiente.

Torregroza \& Harpstead (1967) realizaram seleção divergente para a prolificidade. A seleção para a prolificidade resultou num aumento de $14 \%$ na produção de grãos e $28 \%$ no número de espigas por planta. A seleção para somente uma espiga resultou num aumento de $5 \%$ na produção de grãos e de $7 \%$ no número de espigas por planta. Em estudo posterior, Torregroza (1973) observou aumento de $48 \%$ na prolificidade e $35 \%$ na produção de grãos depois de 11 gerações de seleção para a prolificidade. Laible \& Dirks (1968) concluíram que seleção por um índice composto por número de espigas e a produção de grãos (ENWI) foi superior à seleção baseada somente na produção de grãos.

Mareck \& Gardner (1979) observaram que 10 ciclos de seleção massal para prolificidade correspondeu a um ganho de 0,8 a $0,9 \%$ por ano, o que foi aproximadamente tão efetivo no aumento da produção de grãos quanto 15 gerações de seleção para produção de grãos per se. Ao mesmo tempo, observaram que a seleção para prolificidade causou menor aumento no ciclo e na altura da espiga que a seleção direta 
para a produção de grãos. Na média de 14 ambientes, obtiveram médias de 0,94 espigas por planta em $\mathrm{C}_{0}$ e 1,18 espigas por planta em $\mathrm{C}_{10}$. Concluíram que a seleção deve ter aumentado a freqüência dos alelos que permitem que as populações tirem vantagem em condições ideais de cultivo. Contudo, Morello et al. (1994) não observaram aumento no peso de espigas com um ciclo de seleção massal para prolificidade na população 'CMS$39^{\prime}$.

A seleção para prolificidade pode ser utilizada quando da seleção massal, visando o aumento da adaptação de germoplasma exótico. Compton et al. (1979) mostraram que a seleção massal para o aumento da adaptação e da prolificidade pode resultar no aumento da produção de grãos sem necessariamente mudar outras características que mostram resposta correlacionada com a produção de grãos, como a altura da planta.

A seleção para a prolificidade pode alterar outras características na população, como na altura das plantas e no comprimento das espigas. Singh et al. (1986) observaram redução significativa na altura da planta, de $-1,81 \mathrm{~cm}$ por ciclo, e não significativa para altura da espiga, de $-0,66 \mathrm{~cm}$ por ciclo, com a seleção para a prolificidade. Maita \& Coors (1996) observaram redução de $-0,4$ e $-0,3 \mathrm{~cm}$ por ciclo na altura da planta e da espiga, respectivamente, após 20 ciclos de seleção massal para a prolificidade. Compton et al. (1979), observaram aumento na altura da espiga, altura da planta e do ciclo com a seleção para prolificidade e para a adaptação.

Singh et al. (1986) observaram redução não significativa de $-0,04 \mathrm{~cm}$ por ciclo no comprimento de espiga após quatro ciclos de seleção para a prolificidade. A redução no comprimento médio das espigas é explicado pela aumento da demanda por assimilados nas plantas com duas espigas e a conseqüente redução da quantidade para cada espiga.

Contudo, outros métodos de seleção recorrente também podem ser utilizados com sucesso no melhoramento da prolificidade e na produção de grãos.

Os métodos de seleção recorrente foram desenvolvidos para o melhoramento de caracteres quantitativos em populações de base genética ampla. Sua condução 
envolve três fases: desenvolvimento das progênies, avaliação das progênies em experimentos com repetições, seleção e recombinação das progênies superiores para reconstituição da população para o próximo ciclo de seleção. Então, o objetivo da seleção recorrente é aumentar a médias das características sob seleção (seleção de progênies com genes favoráveis) e manter a variabilidade para futuras seleções (recombinação de progênies superiores) (Lamkey \& Hallauer, 1984). A seleção recorrente é normalmente realizada em populações de ampla base genética e minimiza a endogamia enquanto maximiza a recombinação.

Singh et al. (1986) realizou 4 ciclos de seleção recorrente com o emprego de progênies de irmãos germanos para a prolificidade na população de polinização aberta 'Partap'. Obtiveram uma resposta linear significativa na produção de grãos de $5,5 \%$ por ciclo quando a seleção foi praticada em densidade de 44.444 plantas / hectare e de 3,6\% por ciclo quando a seleção foi praticada em densidade de 166.666 plantas / hectare. As médias foram de 1,06 espigas por planta no ciclo 0 e 1,29 espigas por planta após 4 ciclos de seleção. Concluíram que maiores ganhos na produção deveriam ser esperados da seleção para a prolificidade do que com a seleção direta para a produção de grãos.

Paterniani (1978) propôs um método simples e eficaz de seleção recorrente fenotípica para a prolificidade. Baseia-se na seleção massal para a prolificidade em ambos os sexos. Quando o florescimento se inicia, todas as plantas com segundas espigas são cobertas. Depois de 5 a 10 dias, é retirado o pendão das plantas sem segundas espigas e as espigas das plantas com 2 espigas são descobertas. As sementes colhidas são resultado do cruzamento somente de plantas prolíficas.

Tsotsis (1972) apresentou resultados indicando que a autofecundação da segunda espiga e polinização livre da primeira espiga, para fins de seleção para prolificidade, induz o desenvolvimento de um sistema vascular ou mecanismo bioquímico capaz de alimentar ambas as espigas com eficiência equivalente, em contraste com outros tipos prolíficos onde a segunda espiga sempre é prejudicada em favor da primeira espiga. Goulas \& Lonnquist (1976) relataram sobre dois ciclos de 
seleção combinada de dois tipos de famílias, ou seja, pela média de famílias de meios irmãos e progênies $S_{1}$ obtidas da mesma planta.

Singh et al. (1986) propuseram uma nova metodologia para a seleção recorrente com progênies de irmãos germanos, na qual quatro ciclos de seleção para prolificidade são completados em dois anos. Consiste no plantio dos lotes de polinização quatro a oito semanas após o plantio dos experimentos de avaliação das progênies de irmãos germanos. Somente as progênies com duas ou mais espigas nos experimentos, são recombinadas nos lotes de polinização, permitindo a realização de dois ciclos em um ano agrícola.

O aumento da prolificidade aumenta a estabilidade de produção dos genótipos de milho em distintos ambientes de cultivo (distintas densidades populacionais, fornecimento hídrico e de nutrientes), aumenta a eficiência na transformação dos nutrientes disponíveis em grãos; além de propiciar maior produtividade em ambientes de cultivo adequados. Contudo, a maior parte dos estudos científicos com a prolificidade utilizaram metodologias simples de seleção, como a seleção massal em ambos os sexos, na qual há reduzido controle ambiental na seleção dos materiais superiores. Aliado a isto, são poucos os trabalhos no país que realizaram estudos genéticos da prolificidade e sua relação com a produção de grãos nos materiais aqui adaptados. 


\section{MATERIAL E MÉTODOS}

\subsection{Material}

Foram utilizadas neste trabalho seis populações de polinização livre:.

ITA-PR: Foi derivada da variedade IAC-Taiúba (Instituto Agronômico de Campinas), de porte e ciclo intermediário, com elevado grau de tolerância a alumínio tóxico, após um ciclo de seleção massal para prolificidade (Miranda Filho ${ }^{1}$ ).

Pichilingue: Foi introduzida do Equador, após resultados promissores da avaliação experimental de híbridos simples Pichilingue x Poza Rica no Brasil (Vasco Medina, 1990), tendo se revelado com bom potencial de prolificidade em avaliações visuais.

ESALQ-PR1: É uma população de base genética estreita, originada a partir de uma família de meios irmãos de uma população segregante (ESALQ-PB4 x ESALQPB5) e submetida a um ciclo de seleção fenotípica para prolificidade.

Piranão VD2B: Corresponde à versão braquítica da população ESALQ-VD2, tendo sido empregada a variedade 'Piranão' como fonte doadora do gene $b r_{2}^{2}$. Após o cruzamento inicial, ESALQ-VD2 x 'Piranão', foi efetuado um retrocruzamento para ESALQ-VD2, seguindo-se de três gerações de cruzamentos ao acaso, em lotes isolados, com seleção branda visando maior uniformização da arquitetura das plantas.

\footnotetext{
${ }_{1}^{1}$ MIRANDA FILHO, J.B. (Departamento de Genética, ESALQ/USP). Comunicação pessoal, 1996.

${ }^{2} \mathrm{O}_{\text {gene }} \mathrm{br}_{2}$ é um dos genes maiores que reduzem o porte das plantas de milho. Promove o encurtamento dos internódios, sem afetar o número de folhas. É um dos genes que menos alteram o tamanho da espiga.
} 
Posteriormente, o Piranão VD2B, em pesquisa dirigida à estimação de parâmetros genéticos e fenotípicos, foi submetido a um ciclo de seleção entre progênies de meios irmãos, objetivando o melhoramento de sua produção de grãos (Lordelo, 1982; Soares Filho, 1987).

Piranão VF1B: Refere-se à versão braquítica da variedade ESALQ-VF1. À semelhança da população Piranão VD2B, a população foi obtida através das seguintes etapas: cruzamento ESALQ-VF1 x 'Piranão', retrocruzamento para ESALQ VF1, realização de três gerações de recombinação, acompanhadas por uma seleção fraca com a finalidade principal de uniformizar a arquitetura das plantas. Por ocasião destas gerações de cruzamento ao acaso efetuou-se, também, seleção para grãos do tipo duro ou "flint". Posteriormente, foi praticado um ciclo de seleção entre progênies de meios irmãos, sendo nesta fase obtidas estimativas relativas a parâmetros genéticos e fenotípicos (Lordelo, 1982; Soares Filho, 1987).

Piranão VF1B-P: Constitui-se numa sub-população originada a partir da seleção de progênies com maior potencial prolífico da população Piranão VF1B. A seleção foi baseada em avaliações de progênies de irmãos germanos (IG) interpopulacionais oriundas do cruzamento de Piranão FV1B com Piranão VD2B e vice versa. $\mathrm{O}$ método de cruzamento utilizado para a obtenção das progênies foi o dialélico parcial circulante interpopulacional (Miranda Filho \& Vencovsky, 1999). Baseado nas avaliações das progênies em experimentos com repetições, foram selecionadas 20 progênies das populações que apresentavam maior número de espigas por planta, na média dos 4 cruzamentos. As populações formadas foram denominadas de Piranão VD2B-P e Piranão VF1B-P. Devido ao baixo vigor das sementes de Piranão VD2B-P, não foi possível a obtenção de progênies prolíficas e a população foi descartada deste trabalho.

Como testemunha nos experimentos de avaliação foi utilizado o híbrido triplo modificado comercial XI360 da empresa Braskalb, que apresenta elevada prolificidade e produtividade. 


\subsection{Metodologias}

Foram utilizados dois métodos de seleção recorrente ao nível intrapopulacional, visando o aumento da prolificidade nas populações per se.

\subsubsection{Método Seleção IG}

No presente trabalho, foi utilizado metodologia para seleção recorrente, proposta por Paterniani (1978), com modificações, a qual é descrita a seguir.

A população base foi plantada em época normal de cultivo do milho, utilizando-se espaçamento maior do que o usual para forçar a expressão da prolificidade. Quando da polinização, as plantas com segundas espigas foram polinizadas manualmente por outras plantas com segundas espigas, obtendo-se progênies de irmãos germanos (IG).

O esquema da seleção recorrente para prolificidade com o uso de progênies de irmãos germanos, aqui denominado de Seleção IG, é apresentado na Figura 1.

As progênies foram avaliadas em experimentos com repetições e as superiores quanto ao número de espigas por planta foram selecionadas para compor a população melhorada e o próximo ciclo de seleção teve início.

Os experimentos de avaliação das progênies foram utilizados para estimar parâmetros genéticos em cada ciclo seleção. Nos experimentos do ciclo 1 (avaliação $\mathrm{C}_{01}$ ) foram estimados os parâmetros genéticos das populações após a seleção massal para a prolificidade (Figura 1). Nos experimentos do ciclo 2 (avaliação $\mathrm{C}_{1}$ ) foram estimados os parâmetros genéticos das populações após o primeiro ciclo de seleção (seleção massal e de progênies). Estes experimentos foram utilizados também para a estimação da população melhorada de segundo ciclo $\left(\mathrm{C}_{2}\right)$. 


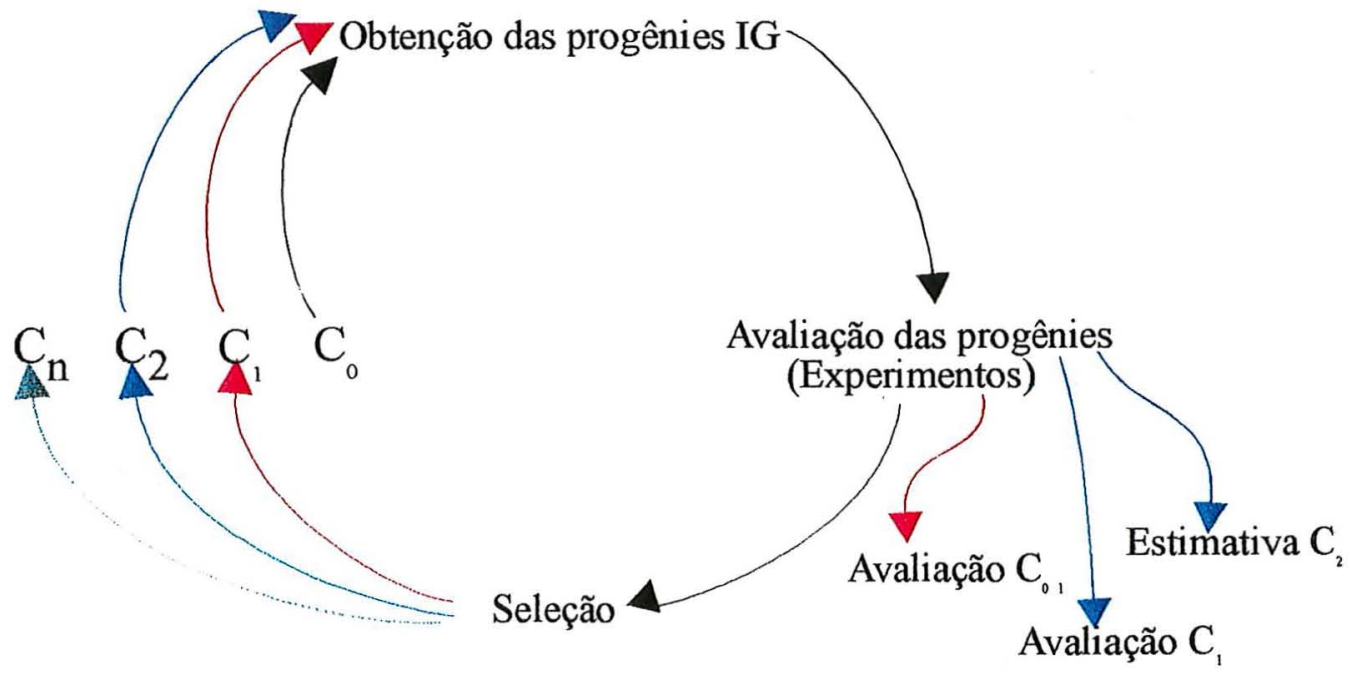

Figura 1. Esquema de seleção recorrente do método Seleção IG.

Como houve seleção massal para a prolificidade para ambos os sexos quando da obtenção das progênies, foram obtidas um número reduzido de progênies por população nos dois ciclos. Deve-se ressaltar também que as progênies avaliadas nos experimentos com repetições após cada ciclo de seleção, não se referem às populações originais $\left(\mathrm{C}_{0}\right)$ ou às populações de primeiro ciclo $\left(\mathrm{C}_{1}\right)$, mas às populações depois da seleção fenotípica para a prolificidade. Portanto, a ocorrência da seleção massal quando da obtenção das progênies, faz com que as estimativas dos parâmetros genéticos não sejam das populações de referência. Apesar disto, os parâmetros genéticos foram calculados depois de cada ciclo para uma análise das propriedades genéticas das populações com respeito à prolificidade como um complemento ao estudo, uma vez que o objetivo primeiro desse trabalho é a avaliação da eficiência dos métodos de seleção para a prolificidade. 


\subsubsection{Método Seleção $\mathrm{S}_{1}$}

Com base no trabalho de Tsotsis (1972), foi utilizada uma variação da seleção recorrente fenotípica para prolificidade, descrita a seguir.

Foram instalados campos de cruzamento com baixa densidade populacional para facilitar a avaliação fenotípica de plantas individuais. Nas plantas com potencial de prolificidade foram protegidas as segundas espigas as quais foram autofecundadas, obtendo-se progênies de autofecundação $\left(S_{1}\right)$. O esquema da seleção recorrente fenotípica do método Seleção $S_{1}$ é apresentado na Figura 2.

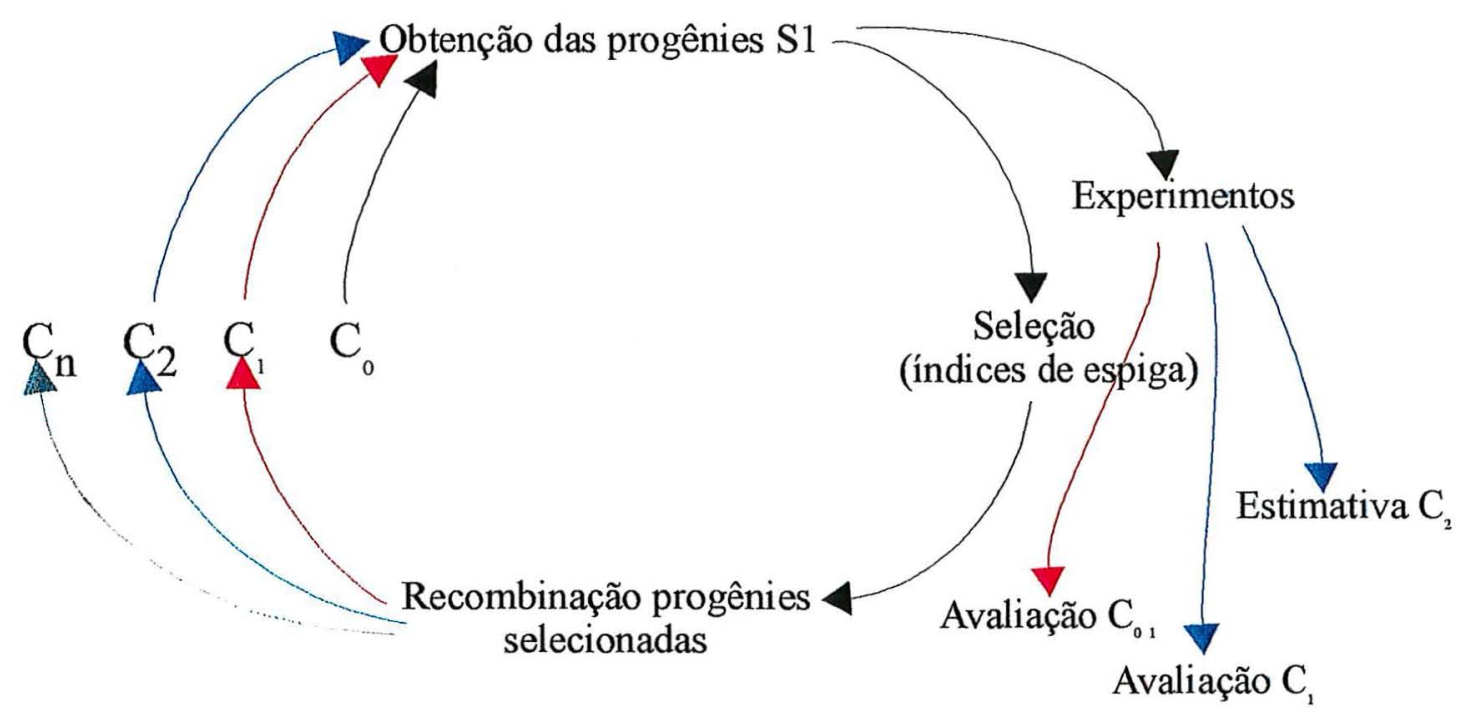

Figura 2. Esquema de seleção recorrente fenotípica do método Seleção $S_{1}$. 
Neste método, foram colhidas as primeiras e as segundas espigas das plantas polinizadas nos lotes de polinização e foram calculados:

- comprimento da primeira (CE1) e da segunda espiga (CE2) (cm);

- diâmetro da primeira (DE1) e da segunda espiga (DE2) (cm);

- peso da primeira (PE1) e da segunda espiga (PE2) (gramas);

- peso de grãos da primeira (PG1) e da segunda espiga (PG2) (gramas).

Após a obtenção destes dados, foram calculadas os índices:

- RDE: divisão do diâmetro da segunda espiga pelo diâmetro da primeira espiga (DE2/DE1);

- RCE: divisão do comprimento da segunda espiga pelo comprimento da primeira espiga (CE2/CE1);

- RPE: divisão do peso da segunda espiga pelo peso da primeira espiga (PE2/PE1);

- RPG: divisão do peso de grãos da segunda espiga pelo peso de grãos da primeira espiga (PG2/PG1).

As trinta progênies superiores quanto aos índices RPE e RPG foram selecionadas e recombinadas para o retorno da população à condição não endógama $\left(\mathrm{S}_{0}\right)$. Ao mesmo tempo, as progênies foram avaliadas em experimentos com repetições para a estimação dos parâmetros genéticos das populações (Figura 2). Os experimentos do primeiro ciclo (avaliação $\mathrm{C}_{01}$ ) foram utilizados para estimação dos parâmetros genéticos das populações após a seleção massal para a prolificidade. Os experimentos do segundo 
ciclo (avaliação $\mathrm{C}_{1}$ ) foram utilizados para a estimação dos parâmetros genéticos das populações após o primeiro ciclo de seleção recorrente fenotípica e para a estimação da população melhorada de segundo ciclo $\left(\mathrm{C}_{2}\right)$.

No método Seleção $S_{1}$ não foi utilizada a informação do teste de progênies, mas tão somente a avaliação fenotípica de plantas individuais. As progênies $S_{1}$ foram avaliadas em experimentos com repetições somente para a análise genética das populações com respeito a prolificidade.

Assim como no método Seleção IG, foram obtidos um número reduzido de progênies por população depois de cada ciclo devido à seleção massal em ambos os sexos para a prolificidade quando da obtenção das progênies. Isso faz com que as estimativas dos parâmetros genéticos não sejam das populações de referência $\left(\mathrm{C}_{0}\right.$ e $\left.\mathrm{C}_{1}\right)$. Estes foram obtidos após cada ciclo somente para uma análise das propriedades genéticas das populações com respeito a prolificidade e adicionar informações sobre a característica à análise dos métodos de melhoramento utilizados.

\subsubsection{Obtenção das progênies e cruzamentos}

No primeiro ciclo de seleção, foram semeadas 1.500 sementes para cada um dos dois métodos intrapopulacionais. O espaçamento utilizado nos lotes, foi maior que o usual para favorecer o aparecimento de plantas prolíficas, consistindo de $0,40 \mathrm{~cm}$ entre plantas e 1,00 entre linhas (Sorrells et al., 1979; Singh et al., 1986).

A semeadura ocorreu na primavera de 1996, na Fazenda Experimental de Anhembi (SP). Os tratos culturais foram realizados conforme os recomendados para a cultura.

$\mathrm{Na}$ época da polinização, todos os lotes tiveram as primeiras e segundas espigas protegidas antes da emissão da barba. Nos lotes onde utilizou-se o método Seleção $S_{1}$, as autopolinizações foram realizadas nas segundas espigas, obtendo-se progênies de 
autofecundação $\left(\mathrm{S}_{1}\right)$. Nos lotes do método Seleção IG, as plantas com barba na segunda espiga, foram polinizadas por outras plantas prolíficas da mesma população, obtendo-se progênies IG.

Na Tabela 1 são apresentados o número de progênies obtidas nos dois ciclos de seleção dos métodos Seleção $S_{1}$ e Seleção IG.

Tabela 1. Número de progênies de milho obtidas nos métodos intrapopulacionais Seleção IG e Seleção $S_{1}$ no primeiro e no segundo ciclo de seleção.

\begin{tabular}{lcccc}
\hline Populações & \multicolumn{3}{c}{$\mathbf{1}^{\mathbf{6}}$ ciclo $^{\mathbf{a}}$} & \multicolumn{2}{c}{$\mathbf{2}^{\mathbf{0}}$ ciclo $^{\mathrm{b}}$} \\
\cline { 2 - 5 } & Seleção IG & Seleção $\mathrm{S}_{1}$ & Seleção IG & Seleção $\mathbf{S}_{1}$ \\
\hline Piranão VF1B - P & 83 & -- & 120 & $-\cdots$ \\
Piranão VD2B & 48 & 54 & 139 & 85 \\
Piranão VF1B & 89 & 62 & 85 & 36 \\
Pichilingue & 79 & 72 & 109 & 100 \\
ITA - PR & 67 & 68 & 125 & 89 \\
HXI & --- & --- & 109 & 53 \\
ESALQ-PR1 & 32 & 40 & --- & 65 \\
\hline
\end{tabular}

${ }^{a}$ Progênies de primeiro ciclo obtidas em Anhembi (1997)

${ }^{\mathrm{b}}$ Progênies de segundo ciclo obtidas em Piracicaba (1998)

No método Seleção $S_{1}$ as 30 progênies $S_{1}$ superiores quanto aos índices de prolificidade RPE e RPG, foram recombinadas e deram origem à população de primeiro ciclo utilizada no plantio do lote de polinização de segundo ciclo. A seleção do número de progênies ocorreu fixando-se o tamanho efetivo de $30(\mathrm{Ne}=30)$.

Foi obtido um reduzido número de progênies por população devido à ocorrência da seleção massal para ambos os sexos quando da obtenção das progênies. 
Devido a isso, optou-se pela fixação do tamanho efetivo para se minimizar a ocorrência da deriva genética ocasionado pelo reduzido tamanho efetivo da população melhorada. Desta forma, a endogamia esperada no primeiro ciclo de seleção, de uma população de $\mathrm{F}_{0}=0$ e $\mathrm{N}_{\mathrm{e}}=30$, é igual a 0,01667 e no segundo ciclo de seleção a endogamia é 0,03305 , valores estes que podem ser considerados não comprometedores para progressos a médio prazo. Estes valores foram calculados segundo a seguinte fórmula $(\mathrm{Li}, 1976)$ :

$$
F_{t}=\frac{1}{2 N_{e}}+\left(1-\left(\frac{1}{2 N_{e}}\right)\right) F_{t-1}
$$

onde

$F_{t}=$ coeficiente de endogamia na geração $t$.

A recombinação das progênies selecionadas foi realizada plantando-se 30 linhas, sendo que cada linha conteve uma semente de cada progênie selecionada. As linhas foram plantadas no campo em espaçamento normal e procedeu-se a polinização entre plantas dentro de cada linha, obtendo-se progênies de irmãos germanos. Depois da colheita, de cada espiga polinizada, foi retirada uma amostra isonumérica de sementes, cuja reunião compôs a população de primeiro ciclo.

As populações de primeiro ciclo semeadas para a obtenção de novas progênies $S_{1}$, no método Seleção $S_{1}$, foram as seguintes: Piranão VF1B, Piranão VD2B, Pichilingue, ITA-PR, ESALQ-PR1 e HXL.

No método de Seleção IG foram selecionadas as 20 progênies com maior número de espigas por planta de cada população, baseado nos testes de progênie dos experimentos. Da mesma forma que no método Seleção $S_{1}$, estabeleceu-se um número fixo de 20 progênies por população para a redução da probabilidade de ocorrência da deriva genética. Como o tamanho efetivo das progênies de irmãos germanos é igual a dois, selecionando-se 20 progênies tem-se $\mathrm{N}_{\mathrm{e}}=40$. $\mathrm{O}$ coeficiente de endogamia, segundo a fórmula (1), no primeiro ciclo é de 0,0125 e no segundo ciclo de seleção de 0,0484 , 
supondo $F_{0}=0$. Estes índices foram inferiores ao método Seleção $S_{1}$, e portanto, a probabilidade de deriva genética neste método é maior que no método Seleção IG.

Foi obtido um reduzido número de progênies da população ESALQ-PR1 no primeiro ciclo, como consequeência do elevado nível de endogamia da população $\left(\mathrm{F}_{0}=\right.$ 0,125 , relativo a uma família de meios irmãos). Devido a isto, a população foi descartada do método Seleção IG no segundo ciclo. O coeficiente de endogamia da população ESALQ-PR1 após o primeiro ciclo de seleção no método Seleção $\mathrm{S}_{1}\left(\mathrm{~N}_{\mathrm{e}}=30\right)$ é igual a 0,1396 e no método Seleção IG $\left(\mathrm{N}_{\mathrm{e}}=40\right)$ é igual a 0,1359 . Portanto, a população ESALQ-PR1 apresenta um alto nível de endogamia que será aumentado progressivamente no processo seletivo. Como a variância genética se reduz devido a endogamia, é esperado que o progresso genético com a seleção para a prolificidade nesta população seja reduzido.

Para a formação das populações de primeiro ciclo, uma amostra isonumérica de sementes foi retirada de cada progênie de irmãos germanos. Como neste método a recombinação ocorre juntamente com a obtenção das novas progênies, as sementes remanescentes das progênies selecionadas foram reunidas e semeadas para obtenção das progênies de segundo ciclo. Neste método, as populações de primeiro ciclo semeadas para a obtenção novas progênies foram: Piranão VF1B, Piranão VD2B, Pichilingue, ITA-PR, Piranão VF1B-P e HXL.

Nos dois métodos intrapopulacionais foi incluído a população HXL, formada a partir da polinização aberta do híbrido triplo XL360, que foi utilizado como testemunha nos experimentos de primeiro ciclo. Optou-se por incluí-lo no trabalho devido à sua grande prolificidade e produtividade. Para a formação da população, foram reunidas amostras isonuméricas de 40 espigas de meios irmãos, obtidas dentro dos experimentos de avaliação das progênies de primeiro ciclo.

Os lotes de polinização de segundo ciclo foram plantados em Piracicaba em 1998, nos moldes dos plantios anteriores. Contudo, foi aumentado o número de plantas utilizadas em cada método para a obtenção de um maior número de progênies. No método Seleção IG foram semeados 2000 sementes e no método Seleção $S_{1}$, foram 
semeadas 3000 sementes de cada uma das populações, no mesmo espaçamento do primeiro ciclo. $\mathrm{O}$ número de progênies obtidas de cada uma das populações no segundo ciclo de seleção é apresentado da Tabela 1.

Após a colheita das espigas dos lotes de polinização, realizou-se a avaliação das primeiras e das segundas espigas das populações da mesma forma descrita no item 3.2.2 para o método Seleção $S_{1}$. Contudo, no segundo ciclo, procedeu-se a avaliação e a obtenção dos índices nas espigas colhidas nos dois métodos intrapopulacionais.

\subsubsection{Instalação dos Experimentos}

A relação dos ensaios de avaliação das progênies dos métodos Seleção IG e método Seleção $S_{1}$ do primeiro e do segundo ciclo de seleção, com número, tipo de progênie, local e ano de plantio são apresentados na Tabela 2. Todos os ensaios foram instalados segundo delineamento de blocos casualizados com três repetições. A parcela experimental foi de 1 linha de 4 metros, com 30 sementes por linha, espaçadas de 0,90 $\mathrm{cm}$. Vinte dias após a emergência, foi realizado o desbaste para um estande de 20 plantas por linha.

Nos experimentos de primeiro ciclo foi utilizada como testemunha o híbrido XL360. Nos experimentos de segundo ciclo, foram utilizadas 2 testemunhas: o híbrido XL360 e a população original $\left(\mathrm{C}_{0}\right)$ de cada uma das populações avaliadas.

Foram instalados onze experimentos com as progênies obtidas nos dois métodos no primeiro ciclo e vinte e quatro experimentos no segundo ciclo. No primeiro ciclo as progênies foram avaliadas em somente um local, em Anhembi (SP) em 1997, e no segundo ciclo as progênies do método Seleção IG foram avaliadas em Anhembi e em Piracicaba e as progênies do método Seleção S1 foram avaliadas em Anhembi em 1999 e 2000 . 
Tabela 2. Relação dos experimentos instalados em 1997 e 1999, para avaliação das progênies de milho de primeiro e segundo ciclo dos métodos Seleção IG e Seleção $S_{1}$.

\begin{tabular}{|c|c|c|c|c|c|}
\hline Experimento & população & $\begin{array}{c}\text { tipo de } \\
\text { progênie }\end{array}$ & $\mathrm{n}^{0}$ progênies & $\begin{array}{l}\text { local de } \\
\text { plantio }\end{array}$ & $\begin{array}{c}\text { Ano } \\
\text { colheita }\end{array}$ \\
\hline EXP102 & Piranão VF1B & $S_{1}^{1}$ & 44 & Anhembi & 1997 \\
\hline EXP103 & Piranão VF1B & $\mathrm{IG}^{1}$ & 73 & Anhembi & 1997 \\
\hline EXP104 & Piranão VD2B & $S_{1}{ }^{1}$ & 43 & Anhembi & 1997 \\
\hline EXP105 & Piranão VD2B & $\mathrm{IG}^{1}$ & 42 & Anhembi & 1997 \\
\hline EXP106 & Pichilingue & $S_{1}^{1}$ & 63 & Anhembi & 1997 \\
\hline EXP107 & Pichilingue & $\mathrm{IG}^{1}$ & 72 & Anhembi & 1997 \\
\hline EXP108 & ITA & $S_{1}{ }^{1}$ & 55 & Anhembi & 1997 \\
\hline EXP109 & ITA & $\mathrm{IG}^{1}$ & 60 & Anhembi & 1997 \\
\hline EXP110 & ESALQ-PR1 & $S_{1}{ }^{1}$ & 26 & Anhembi & 1997 \\
\hline EXP111 & ESALQ-PR1 & $\mathrm{IG}^{1}$ & 27 & Anhembi & 1997 \\
\hline EXP112 & Piranão VF1B-P & $\mathrm{IG}^{1}$ & 83 & Anhembi & 1997 \\
\hline EXP 56 & Piranão VF1B-P & $\mathrm{IG}^{2}$ & 110 & Anhembi & 1999 \\
\hline EXP 57 & Piranão VF1B & $\mathrm{IG}^{2}$ & 81 & Anhembi & 1999 \\
\hline EXP 58 & ITA-PR & $\mathrm{IG}^{2}$ & 122 & Anhembi & 1999 \\
\hline EXP 59 & Pichilingue & $\mathrm{IG}^{2}$ & 92 & Anhembi & 1999 \\
\hline EXP 60 & Piranão VD2B & $\mathrm{IG}^{2}$ & 135 & Anhembi & 1999 \\
\hline EXP 61 & HXL & $\mathrm{IG}^{2}$ & 103 & Anhembi & 1999 \\
\hline EXP 62 & Piranão VD2B & $\mathrm{S}_{1}^{2}$ & 85 & Anhembi & 1999 \\
\hline EXP 63 & Pichilingue & $\mathrm{S}_{1}{ }^{2}$ & 100 & Anhembi & 1999 \\
\hline EXP 64 & ITA-PR & $\mathrm{S}_{1}{ }^{2}$ & 89 & Anhembi & 1999 \\
\hline EXP 65 & HXI & $\mathrm{S}_{1}^{2}$ & 53 & Anhembi & 1999 \\
\hline EXP 66 & ESALQ-PR1 & $\mathrm{S}_{1}{ }^{2}$ & 65 & Anhembi & 1999 \\
\hline EXP 79 & Piranão VF1B & $\mathrm{S}_{1}{ }^{2}$ & 32 & Anhembi & 1999 \\
\hline EXP 67 & Piranão VF1B-P & $\mathrm{IG}^{2}$ & 110 & Piracicaba & 1999 \\
\hline EXP 68 & Piranão VF1B & $\mathrm{IG}^{2}$ & 81 & Piracicaba & 1999 \\
\hline EXP 69 & ITA-PR & $\mathrm{IG}^{2}$ & 122 & Piracicaba & 1999 \\
\hline EXP 70 & Pichilingue & $\mathrm{IG}^{2}$ & 92 & Piracicaba & 1999 \\
\hline EXP 71 & Piranão VD2B & $\mathrm{IG}^{2}$ & 135 & Piracicaba & 1999 \\
\hline EXP 72 & HXI & $\mathrm{IG}^{2}$ & 103 & Piracicaba & 1999 \\
\hline EXP 73 & Piranão VF1B & $\mathrm{S}_{1}{ }^{2}$ & 32 & Anhembi & 2000 \\
\hline EXP 74 & Piranão VD2B & $S_{1}^{2}$ & 85 & Anhembi & 2000 \\
\hline EXP 75 & Pichilingue & $\mathrm{S}_{1}^{2}$ & 100 & Anhembi & 2000 \\
\hline EXP 76 & ITA-PR & $\mathrm{S}_{1}{ }_{2}$ & 89 & Anhembi & 2000 \\
\hline EXP 77 & HXL & $\mathrm{S}_{1}{ }_{2}$ & 53 & Anhembi & 2000 \\
\hline EXP 78 & ESALQ-PR1 & $\mathrm{S}_{1}{ }^{2}$ & 65 & Anhembi & 2000 \\
\hline
\end{tabular}

${ }^{T}$ Progênies de primeiro ciclo avaliadas em 1997.

${ }^{2}$ Progênies de segundo ciclo avaliadas em 1999 e 2000. 
Em todos os experimentos, foram avaliados os parâmetros :

- Altura da planta (AP): Comprimento do solo à inserção da última folha do colmo, $\mathrm{em} \mathrm{cm}$. Foi realizado em cinco plantas representativas da parcela;

- Altura da espiga (AE): Relativo ao comprimento do solo à inserção da primeira espiga no colmo, em $\mathrm{cm}$. Realizado em cinco plantas representativas da parcela;

- Estande (ST): Constituiu na contagem do número de plantas de cada parcela, um pouco antes da colheita;

- Número de espigas (NE): Número de espigas da parcela;

- Peso de espigas (Pe): Peso total de espigas da parcela, em kg;

Nos experimentos de primeiro ciclo e em Piracicaba no segundo ciclo, foram obtidos também os seguintes parâmetros:

- Comprimento das espigas (CE): Comprimento de cinco espigas representativas da parcela, em cm;

- Diâmetro das espigas (DE): Diâmetro de cinco espigas representativas da parcela, em cm;

- Peso de grãos (Pg): Peso total de grãos da parcela, em kg;

- Prolificidade ou número de espigas por planta (NEP): Obtido pela divisão do número de espigas da parcela pelo número de plantas da parcela (NE/ST);

- Peso de espigas corrigido (PE): O peso de espigas das parcelas foi corrigido pelo estande ideal de plantas da parcela ( 20 plantas), utilizando a fórmula de regressão (Miranda Filho ${ }^{3}$; Vencovsky \& Barriga, 1992):

\footnotetext{
${ }^{3}$ MIRANDA FILHO, J.B. (Departamento de Genética, ESALQ/USP). Comunicação pessoal.
} 


$$
\hat{Y}_{i j}=Y_{i j}-\hat{b}\left(X_{i j}-N\right)
$$

onde

$\hat{Y}_{i j}=$ produção de espigas ajustada da parcela;

$Y_{i j}=$ produção de espigas observada da parcela;

$X_{i j}=$ estande observado da parcela;

$N=$ estande ideal, igual a 20 de plantas por parcela;

$b=$ coeficiente de regressão linear do estande sobre a produção de espigas.

O coeficiente de correlação linear de cada experimento $(b)$ foi obtido pela análise de variância do estande e da análise de covariância entre peso de espigas e estande, no delineamento de blocos ao acaso. O coeficiente de regressão linear foi obtido pela fórmula abaixo:

$$
b=\frac{S P_{e}}{S Q_{e}}
$$

Onde:

$S P_{e}=$ soma de produtos residual da análise de covariância;

$S Q_{e}=$ soma de produtos residual da análise de variância.

- Peso de grãos corrigido (PG): realizado da mesma forma que o peso de espigas corrigido. 


\subsubsection{Análise estatística dos dados dos experimentos}

\subsubsection{Análise de variância e estimação dos parâmetros genéticos}

Primeiramente, foi realizada a análise estatística individual para cada experimento, no delineamento blocos ao acaso com modelo aleatório (Tabela 3), utilizando o seguinte modelo estatístico:

$$
Y_{i k}=m+g_{i}+b_{k}+e_{i k}
$$

Onde:

$Y_{i k}=$ é o valor observado do parâmetro;

$m=$ é a média do experimento;

$g_{i}=$ é o efeito aleatório de progênies $i$;

$b_{k}=$ é o efeito aleatório do bloco $k$,

$e_{i k}=$ é o efeito do erro experimental.

Tabela 3. Esquema da análise de variância em blocos ao acaso.

\begin{tabular}{lccl}
\hline FV & G.L. & QM & E (QM) \\
\hline Blocos & $\mathrm{r}-1$ & - & - \\
Progênies & $\mathrm{g}-1$ & $\mathrm{Q} 1$ & $\sigma^{2}+\mathrm{r}_{\mathrm{p}}^{2}$ \\
Resíduo & $(\mathrm{r}-1)(\mathrm{g}-1)$ & $\mathrm{Q} 2$ & $\sigma^{2}$ \\
Total & $\mathrm{rg}-1$ & & \\
\hline
\end{tabular}

Onde: $\mathrm{k}=1,2, \ldots, \mathrm{r}$ blocos; $\mathrm{i}=1,2, \ldots, \mathrm{g}$ progênies.

As estimativas dos componentes de variância foram:

$$
\begin{gathered}
\hat{\sigma}^{2}=\mathrm{Q} 2 \\
\hat{\sigma}_{\mathrm{p}}^{2}=\frac{\mathrm{Q} 1-\mathrm{Q} 2}{2}
\end{gathered}
$$

Onde: 
$\hat{\sigma}_{p}^{2}=$ estimativa da variância entre progênies ao nível de médias;

$\hat{\sigma}^{2}=$ estimativa da variância residual

e a estimativa da herdabilidade o nivel de médias no sentido amplo:

$$
\begin{gathered}
\hat{h}_{p}^{2}=\frac{\hat{\sigma}_{p}^{2}}{\hat{\sigma}_{p}^{2}+\frac{\hat{\sigma}^{2}}{r}} \\
\text { ou } \hat{h}_{p}^{2}=\frac{Q 1-Q 2}{Q 1}
\end{gathered}
$$

E o conteúdo genético das progênies:

$$
\sigma_{p}^{2}=\frac{1}{2} \sigma_{A}^{2}+\frac{1}{4} \sigma_{D}^{2} \text { para famílias de irmãos germanos (IG) e }
$$

$$
\sigma_{p}^{2}=\sigma_{A}^{2}+D_{1}+\frac{1}{4} \sigma_{D}^{2}+\frac{1}{8} D_{2} \text { para progênies de autofecundação }\left(\mathrm{S}_{1}\right)
$$

quando a população original é não endogâmica.

Onde:

$\sigma_{A}^{2}=$ variância genética aditiva;

$\sigma_{D}^{2}=$ variância genética dominante; e

$D_{I}=$ covariância genética entre os efeitos médios (aditivos) dos alelos e os efeitos de dominância dos homozigotos;

$D_{2}=$ variância dos efeitos de dominância nos homozigotos. 
Nos experimentos de segundo ciclo, após a análise individual, foi realizado a análise de variância conjunta, considerando-se o efeito de progênies aleatório e o efeito de locais fixo, utilizando o seguinte modelo estatístico misto:

$$
Y_{i j k}=m+g_{i}+l_{j}+(g)_{i j}+b_{k(j)}+e_{i j k}
$$

Onde:

$Y_{i j k}=$ é o valor observado do parâmetro;

$\boldsymbol{m}=$ é a média do experimento;

$g_{i}=$ é o efeito aleatório de progênies $i$;

$l_{j}=$ é o efeito fixo do local $j$;

$(g l)_{i j}=$ é o efeito da interação do genótipo $i$ com o local $j$;

$g_{k(j)}=$ é o efeito aleatório do bloco $k$ dentro do local $j$;

$e_{i j k}=$ é o erro experimental.

A anova da análise conjunta é apresentada na Tabela 4.

Tabela 4. Esquema de análise de variância conjunta dos experimentos.

\begin{tabular}{lcccl}
\hline FV & G.L. & QM & F & \multicolumn{1}{c}{ E (QM) } \\
\hline Blocos/Local & $1(\mathrm{r}-1)$ & $\mathrm{Q} 1$ & $\mathrm{Q} 1 / \mathrm{Q} 5$ & $\sigma^{2}+\mathrm{g} \sigma^{2}{ }_{\mathrm{B}}$ \\
Local & $1-1$ & $\mathrm{Q} 2$ & $(\mathrm{Q} 2+\mathrm{Q} 5) /$ & $\sigma^{2}+\mathrm{r} \frac{l}{l-1} \sigma_{\mathrm{GL}}^{2}+\mathrm{g} \sigma^{2}{ }_{\mathrm{B}}+\mathrm{rgV} \mathrm{L}_{\mathrm{L}}$ \\
& & & $(\mathrm{Q} 1+\mathrm{Q} 4)$ & \\
Progênies & $\mathrm{g}-1$ & $\mathrm{Q} 3$ & $\mathrm{Q} 3 / \mathrm{Q} 5$ & $\sigma^{2}+\mathrm{rl} \sigma_{\mathrm{G}}^{2}$ \\
Local x Prog. & $(1-1)(\mathrm{g}-1)$ & $\mathrm{Q} 4$ & $\mathrm{Q} 4 / \mathrm{Q} 5$ & $\sigma^{2}+\mathrm{r} \frac{l}{l-1} \sigma_{\mathrm{GL}}^{2}$ \\
Erro & $1(\mathrm{r}-1)(\mathrm{g}-1)$ & $\mathrm{Q} 5$ & & $\sigma^{2}$ \\
\hline
\end{tabular}

Onde: $\mathrm{i}=1,2, . ., \mathrm{g}$ progênies; $\mathrm{j}=1,2, \ldots, 1$ locais e $\mathrm{k}=1,2, \ldots, \mathrm{r}$ blocos por local. 
A análise conjunta foi realizada somente para verificar a ocorrência da interação genótipo $\mathrm{x}$ ambiente nas características. No método Seleção $\mathrm{IG}$, os experimentos foram instalados em Anhembi (SP) e Piracicaba (SP) e como estes locais não são considerados representativos de uma região, pois apresentam características totalmente distintas, toda a análise e interpretação dos resultados e estimativas dos parâmetros genéticos foi realizado em separado para cada local.

No método Seleção $S_{1}$ os experimentos de segundo ciclo foram instalados em dois anos, em 1999 e em 2000, em Anhembi (SP). Portanto, na análise de variância conjunta, o efeito de local no modelo estatístico foi substituído pelo efeito de ano nos experimentos de avaliação das progênies $S_{1}$.

\subsubsection{Progressos e respostas correlacionadas, esperadas com a seleção}

A expressão do ganho genético para seleção entre progênies de irmãos germanos (método Seleção IG) foi (Vencovsky \& Barriga, 1992):

$$
G_{S}=\frac{k(1 / 2) \sigma_{A}^{2}}{\sigma_{\bar{y}_{\bar{p}}}}
$$

considerando-se a população melhorada não endógama.

pois

$$
\operatorname{cov}_{g_{1 G}}=\left(\frac{1}{2}\right) \sigma_{A}^{2}
$$

Onde

$\operatorname{cov}_{g_{I G}}=$ covariância genética das progênies de irmãos germanos;

$\sigma_{y_{\bar{p}}}=$ desvio padrão fenotípico das médias de progênies. 
A expressão do ganho genético com a seleção intrapopulacional entre progênies $S_{1}$ (método Seleção $S_{1}$ ), em ambos os sexos é (Souza Júnior, 1989):

$$
G_{s}=\frac{k \sigma_{A}^{2}+\frac{1}{2} D_{1}}{\sigma_{y_{\bar{p}}}}
$$

pois

$\operatorname{cov}_{g_{S 1}}=\sigma_{A}^{2}+\left(\frac{1}{2}\right) D_{1}$, quando a seleção é realizada entre progênies de autofecundação $\left(\mathrm{S}_{1}\right)$.

Onde

$\operatorname{cov}_{g_{S 1}}=$ covariância genética de progênies de autofecundação $\left(S_{1}\right)$.

considerando-se a população melhorada (oriunda da recombinação de $S_{1}$ ) não endógama.

Portanto, o ganho genético obtido trabalhando-se com progênies $S_{1}$ é maior que o ganho genético com famílias de irmãos germanos quando o componente $D_{l}$ não é negativo, pois esta última explora toda a variância genética aditiva dos materiais,.

A estimativa do ganho genético foi calculado da seguinte forma:

$$
\hat{G}_{S}=d_{S} \cdot \hat{h}_{p}^{2}
$$

ou

$$
\hat{G}_{S}=k \hat{\sigma}_{y_{\bar{P}}} \cdot \hat{h}_{p}^{2}
$$

Em porcentagem:

$$
\% \hat{G}_{S}=\frac{\hat{G}_{s}}{\bar{x}} \cdot 100
$$

e

$$
{ }^{\wedge} \bar{F}=\sqrt{\frac{Q I}{r}}
$$


Onde

Q1= quadrado médio de progênies da análise de variânica;

$\hat{G}_{S}=$ estimativa do ganho genético;

$d_{s}=$ diferencial de seleção ou a média das progênies selecionadas menos a média da população original $\left(\bar{X}_{S}-\bar{X}_{o}\right)$;

$\bar{x}=$ média da população original (antes da seleção).

O $k$ (diferencial de seleção em unidades de desvio padrão) foi calculado considerando-se a seleção das 20 progênies superiores no método Seleção IG e das 30 progênies superiores no método Seleção $\mathrm{S} 1$. Então $k$ foi distinto para cada experimento, pois, os experimentos apresentaram números distintos de progênies sendo avaliadas. Foi utilizado tabela específica para tamanhos amostrais $>50$, para os experimentos com número de progênies maior que este número e tabela para tamanhos amostrais $\leq 50$ para experimentos com número de progênies menor ou igual a 50.

As análises de covariância entre a produção de espigas e a prolificidade foram efetuadas a partir das análises individuais de cada característica e da soma das características, dois a dois. $\mathrm{O}$ esquema de análise de covariância do número de espigas por planta e a produção de espigas, com as esperanças dos produtos médios, é apresentado na Tabela 5 .

Tabela 5. Análise de covariância da produção de espigas (médias de parcela) com o número de espigas por planta (médias de parcela).

\begin{tabular}{|c|c|c|c|c|c|}
\hline & \multicolumn{3}{|c|}{ Quadrados Médios (QM) } & Produtos médios (PM) & $\mathrm{E}(\mathrm{PM})$ \\
\hline & $\mathbf{x}$ & $\mathrm{y}$ & $x+y$ & $x, y$ & \\
\hline Progênies (P) & $\mathrm{QMP}_{\mathrm{x}}$ & $\mathrm{QMP}_{\mathrm{y}}$ & $\mathrm{QMP}_{\mathrm{x}+\mathrm{y}}$ & $\mathrm{PMP}_{x, y}=1 / 2\left(\mathrm{QMP}_{x+y}-\mathrm{QMP}_{\mathrm{x}}-\mathrm{QMP}_{\mathrm{y}}\right)$ & $(1 / n) \operatorname{Cov}_{\mathrm{d}}+\operatorname{Cov}_{\mathrm{e}}+\mathrm{r} \operatorname{Cov}_{l}$ \\
\hline Erro (E) & $\mathrm{QME}_{\mathrm{x}}$ & $\mathrm{QME}_{\mathrm{y}}$ & $\mathrm{QME}_{\mathrm{x}+\mathrm{y}}$ & $\mathrm{PME}_{\mathrm{x}, \mathrm{y}}=1 / 2\left(\mathrm{QME}_{\mathrm{x}+\mathrm{y}}-\mathrm{QME} \mathrm{E}_{\mathrm{x}}-\mathrm{QME}_{\mathrm{y}}\right)$ & $(1 / n) \operatorname{Cov}_{d}+\operatorname{Cov}_{e}$ \\
\hline
\end{tabular}

$\mathrm{Cov}_{\mathrm{e}}$ : covariância do erro experimental entre parcelas;

$\mathrm{Cov}_{\mathrm{p}}$ : covariância genética entre progênies;

r: número de repetições; 
n: número de plantas por parcela.

Considerando-se que a produção de espigas e o número de espigas por planta estão ao nível de médias de parcela, a estimativa da covariância entre as características foi obtida da seguinte forma:

$$
C \hat{o} v_{p_{\alpha x)}}=\frac{P M P_{x, y}-P M E_{x, y}}{r}
$$

Sendo que

$$
\begin{aligned}
& \operatorname{Cov}_{\left.p_{(X Y}\right)}=1 / 2 \operatorname{Cov}_{A_{(X Y)}} \text { para progênies de irmãos germanos e } \\
& \operatorname{Cov}_{p_{(X Y)}}=\operatorname{Cov}_{A_{(X Y)}} \text { para progênies de autofecundação }\left(\mathrm{S}_{1}\right)
\end{aligned}
$$

As estimativas das correlações genéticas foram:

$$
r_{g}(x, y)=\frac{C \hat{o} v_{p(x, y)}}{\sqrt{\hat{\sigma}_{p x}^{2} \cdot \hat{\sigma}_{p y}^{2}}}
$$

Onde:

$\sigma_{p x}^{2}=$ variância de progênies da característica $\mathrm{x}$;

$\sigma_{p y}^{2}=$ variância de progênies da característica y.

e a correlação fenotípica entre médias de progênies:

$$
r \bar{F}(x, y)=\frac{C \hat{o} v_{\bar{F}(x, y)}}{\sqrt{\hat{\sigma}_{\bar{F} x}^{2} \cdot \hat{\sigma}_{\bar{F}_{y}}^{2}}}
$$


ou

$$
r_{\bar{F} x, y}=\frac{C \hat{o} v_{p(x, y)}+\frac{C \hat{o} v_{e(X Y)}}{r}+\frac{C \hat{o} v_{d(X)}}{r n}}{\sqrt{\left(\hat{\sigma}_{p x}^{2}+\frac{\hat{\sigma}_{e x}^{2}}{r}+\frac{\hat{\sigma}_{d x}^{2}}{r n}\right) \cdot\left(\hat{\sigma}_{p y}^{2}+\frac{\hat{\sigma}_{e y}^{2}}{r}+\frac{\hat{\sigma}_{d y}^{2}}{r n}\right)}}
$$

Cuja estimativa foi:

$$
r_{\bar{F}}(x, y)=\frac{P M P_{(x, y)}}{\sqrt{Q M P_{X} \cdot Q M P_{Y}}}
$$

A resposta correlacionada da seleção do número de espigas por planta sobre a produção de espigas tem a seguinte expressão:

$$
\begin{gathered}
R \hat{C}_{x, y}=k \frac{1 / 2 C \hat{o} v_{A(x y)}}{\hat{\sigma}_{\bar{F}(Y)}} \text { para seleção de progênies de irmãos germanos } \\
R \hat{C}_{x, y}=k \frac{C \hat{o} v_{A(x y)}}{\hat{\sigma}_{\bar{F}(Y)}} \text { para seleção de progênies de autofecundação }\left(\mathrm{S}_{1}\right)
\end{gathered}
$$

Onde

$R \hat{C}_{x, y}=$ resposta correlacionada da prolificidade $(y)$ na produção de espigas $(x) ;$

$\operatorname{Cov}_{p(X Y)}=1 / 2 \operatorname{Cov}_{A(X Y)}$ para progênies de irmãos germanos;

$\operatorname{Cov}_{p(X Y)}=\operatorname{Cov}_{A(X Y)}$ para progênies de autofecundação $\left(\mathrm{S}_{1}\right)$;

$\hat{\sigma}_{\bar{F}(Y)}=$ desvio padrão fenotípico entre médias de progênies.

Portanto, a resposta correlacionada esperada das progênies de autofecundação $\left(S_{1}\right)$ é maior que a resposta esperada das progênies de irmãos germanos. 
A depressão endogâmica dos parâmetros produção de espigas e prolificidade em cada ciclo de seleção foi calculada com a expressão:

$$
I=m_{I G}-m_{S_{1}}
$$

Onde:

$I=$ depressão por endogamia;

$m_{I G}=$ média das progênies de irmãos germanos;

$m_{S_{1}}=$ média das progênies de autofecundação $\left(S_{1}\right)$. 


\section{RESULTADOS E DISCUSSÃO}

\subsection{Médias das populações nos ciclos de seleção}

Nas Tabelas 6 e 7 são apresentadas as médias dos parâmetros avaliados nas populações submetidas aos dois ciclos seletivos, no método Seleção IG, avaliados em Anhembi e em Piracicaba, respectivamente.

A média do número de espigas por planta ou prolificidade (NEP) no ciclo 1 $\left(\mathrm{C}_{1}\right)$ foi superior ao ciclo $0\left(\mathrm{C}_{0}\right)$ em todas as populações submetidas ao método Seleção IG. No ciclo 0 as menores médias foram da população Piranão VD2B, com $0,991 \mathrm{e}$ 0,971 espigas por planta em Anhembi e Piracicaba, respectivamente, e da população Pichilingue, com 0,939 espigas por planta em Piracicaba. No ciclo 1, a população Piranão VF1B apresentou a maior média, de 1,240 espigas por planta e a população Pichilingue a menor média, de 1,006 espigas por planta, ambas em Piracicaba.

O ciclo $01\left(\mathrm{C}_{01}\right)$ refere-se à média populacional depois da seleção massal mas antes da seleção pelo teste de progênie (Figura 1), ou seja, a média de todas as progênies de irmãos germanos do primeiro ciclo de seleção em Anhembi. Como estes dados foram obtidos em época diferente aos resultados do Ciclo 0 e do Ciclo 1, não se deve realizar comparações maiores entre eles. Os dados foram aqui adicionados somente para análise geral da tendência da seleção.

A seleção massal foi eficiente na seleção para a prolificidade em todas as populações em Anhembi. Os valores do ciclo 01 são intermediários entre os do Ciclo $0 \mathrm{e}$ os do Ciclo 1 indicando que o ganho genético obtido no teste de progênies de irmãos 
germanos foi adicionado aos ganhos com a seleção fenotípica para a prolificidade quando da obtenção das progênies. $O$ peso de espigas, altura da planta e altura da espiga não apresentaram a mesma tendência do número de espigas por planta. $O$ peso de espigas no ciclo 01 foi maior do que no ciclo 1 e a altura da planta e da espiga foram menores em todas as populações, com exceção da população ITA-PR. Isto indica que a prolificidade apresentou valores mais consistentes, com menor influência ambiental do que a altura da planta e a produção de espigas.

As populações Piranão VF1B-P, Piranão VF1B e ITA-PR nos dois locais, Pichilingue em Anhembi e Piranão VD2B em Piracicaba apresentaram médias no ciclo 1 superior à média do híbrido XL 360. Este híbrido apresenta alta prolificidade e produtividade em condições normais de plantio. Estes dados evidenciam a eficiência do método Seleção IG para a seleção para prolificidade. Os valores de prolificidade obtidos no método intrapopulacional Seleção IG foram similares aos valores encontrados na literatura (Mareck \& Gardner, 1979; Singh et al.,1986; Soares Filho, 1987).

Neste trabalho, com apenas um ciclo de seleção, das 12 médias de número de espigas por planta no método Seleção IG, foram obtidos valores superiores a 1,18 espigas por planta em 6 estimativas, e superiores a 1,12 espigas por planta em 8 estimativas.

$\mathrm{O}$ peso de espigas (PE) das populações submetidas ao método Seleção IG foi superior no ciclo 1 em relação ao ciclo 0 em todas as populações e locais, com exceção da população ITA-PR nos dois locais. No ciclo 1 população Piranão VF1B, avaliada em Piracicaba, apresentou o maior peso de espigas, com $125,8 \mathrm{~g} /$ planta e a população Piranão VD2B, avaliada em Anhembi, apresentou a menor peso de espigas com 96,5 g/planta. Todas as populações submetidas ao método Seleção IG apresentaram peso de espigas inferior à média da testemunha nos dois locais, com exceção da população Piranão VF1B-P em Piracicaba, que apresentou peso de espigas de $101,5 \mathrm{~g} /$ planta. Apesar do maior ou equivalente índice de prolificidade das populações do segundo ciclo quando comparadas com a testemunha, a produtividade não acompanhou estes índices, o 
que era esperado, pois o híbrido apresenta maior potencial produtivo do que as populações de polinização aberta aqui estudadas.

Ocorreu pequena alteração na altura da planta e da espiga das populações com a seleção para a prolificidade no método Seleção IG do ciclo 0 para o ciclo 1 (Tabelas $6 \mathrm{e}$ 7). A maior alteração ocorreu na população Piranão VF1B em Piracicaba, cuja altura da planta passou de $223 \mathrm{~cm} \mathrm{em} \mathrm{C}_{0}$ para $228 \mathrm{~cm} \mathrm{C}_{1}$, e a altura de espiga de 132 em $\mathrm{C}_{0}$ para 142 em $C_{1}$. As outras populações reduziram a altura da planta como resposta à seleção para a prolificidade, com diferenças de 0 a $4 \mathrm{~cm}$ entre os ciclos. As diferenças na altura da espiga entre os ciclos foi de -4 a $10 \mathrm{~cm}$, mas a seleção reduziu ou manteve a altura da espiga na maior parte das populações, com exceção da população HXI em Anhembi e Piranão VF1B nos dois locais.

Houve tendência de aumento da posição relativa da espiga na planta (PRE) no método Seleção IG nos dois locais com a seleção para a prolificidade. As populações Pichilingue em Anhembi e Piracicaba e Piranão VF1B-P em Piracicaba, reduziram a posição relativa da espiga na planta e todas as outras aumentaram a relação com a seleção. Isto ocorreu devido à tendência de redução da altura da planta (AP) e de manutenção da altura da espiga nas populações com a seleção, com exceção da população Piranão VF1B, em que a seleção aumentou a altura da planta e da espiga nos dois locais.

Estes resultados concordam com alguns resultados da literatura (Singh et al., 1986; Maita \& Coors, 1996). Contudo, alguns trabalhos mostram maior altura da planta e da espiga em materiais prolíficos, quando comparado com os não prolíficos (Brotslaw et al., 1988; Subandi, 1990). As diferenças entre os resultados encontrados é explicada pelas diferenças de ciclo entre os genótipos e a metodologia de seleção para a prolificidade. As respostas na altura da espiga e da planta entre os trabalhos com prolificidade ocorrem devido à seleção ou não concomitante para a precocidade, pois esta tem correlação com a altura da planta (Maita \& Coors, 1996).

$\mathrm{Na}$ seleção para a prolificidade, há necessidade da coincidência do florescimento da segunda espiga e do florescimento masculino. Para que isto ocorra, a 
planta receptora de pólen não pode possuir ciclo muito aquém da média da população, sob pena de não ser polinizada a tempo da presença suficiente de pólen. Portanto, as metodologias de seleção para a prolificidade aqui estudadas também selecionam para a redução ou manutenção do ciclo das populações. No método Seleção $S_{1}$ há necessidade de coincidência do florescimento masculino e da segunda espiga da mesma planta $e$, portanto, as plantas polinizadas devem possuir esta sincronia e serem mais precoces. Devido a isto, a redução da altura das plantas no método Seleção $S_{1}$ foi maior do que no método Seleção IG.

Ocorreu redução no comprimento de espiga (CE) e diâmetro de espiga (DE) em todas as populações do método Seleção IG avaliadas em Piracicaba (Tabela 7), com a seleção para a prolificidade. Em todas as populações a redução no comprimento de espigas foi inferior a $1 \mathrm{~cm}$. A maior redução ocorreu na população Piranão VF1B-P, cujo comprimento de espiga passou de $17,7 \mathrm{~cm}$ em $C_{0}$ para 16,8 em $C_{1}$. No diâmetro de espigas (DE) ocorreu alteração inferior a $0,2 \mathrm{~cm}$ de $C_{0}$ para $C_{1}$.

A redução no comprimento e no diâmetro de espigas é normal com a seleção para a prolificidade, uma vez que o aumento no número de espigas por planta acarreta redução do tamanho individual das espigas, como compensação pela aumento do número de drenos (espigas) competindo por assimilados (Singh et al., 1986).

Nas Tabelas 8 e 9 são apresentadas as médias dos parâmetros avaliados nas populações submetidas aos dois ciclos seletivos, no método Seleção $S_{1}$, avaliados em Anhembi em 1999 e 2000. Como a expressão da prolificidade é muito influenciada pelas condições ambientais, os dados dois anos são apresentados e discutidos separadamente para uma análise mais acurada da característica.

Do ciclo 0 para o ciclo 1 , a seleção aumentou a prolificidade nas populações ITA-PR, ESALQ-PR1 e Pichilingue nos dois anos, na população HXL em 1999 e redução na prolificidade nas populações Piranão VD2B e Piranão VF1B nos dois anos e na população $\mathrm{HXL}$ em 2000. O maior aumento no número de espigas por planta ocorreu na população ITA-PR nos dois anos, que passou de 1,105 e 1,114 espigas por planta em $C_{0}$ para 1,206 e 1,140 espigas por planta em $C_{1}$ em 1999 e 2000 , respectivamente. A 
população HXL apresentou o maior número de espigas por planta no ciclo 1 do método Seleção $S_{1}$, de 1,221 espigas por planta em 1999. Isto provavelmente é resultado da menor carga genética desta população por ter sido originada de um híbrido.

As populações Piranão VF1B e Piranão VD2B apresentaram redução na prolificidade, com a utilização do método Seleção $S_{1}$. Estas populações reduziram a prolificidade de 1,143 e 1,074 espigas por planta em $\mathrm{C}_{0}$ para 1,081 e 0,941 espigas por planta em $\mathrm{C}_{1}$ em 1999, respectivamente, e de 1,046 e 1,063 em $\mathrm{C}_{0}$ para 1,032 e 1,012 em $\mathrm{C}_{1}$ em 2000, respectivamente. Esse efeito negativo da seleção para a prolificidade pode ser resultado de dois fatores: a) depressão por endogamia, devido a homozigoze de genes deletérios ou letais ou b) efeito negativo do gene $b r_{2}$.

A depressão por endogamia pode afetar negativamente a prolificidade (Sing $e t$ al., 1967; Good \& Hallauer, 1977; Nass, 1992). No método Seleção $\mathrm{S}_{1}$ é grande a necessidade de coincidência do florescimento masculino e o florescimento da segunda espiga. Em populações com reduzido potencial prolífico, como é o caso das populações Piranão, a obtenção de progênies $S_{1}$ nas segundas espigas pode levar à seleção intensa, ou seja, a variabilidade é reduzida drasticamente. Isto tem reflexos nos níveis de endogamia da população e, consequentemente, na depressão por endogamia.

Por outro lado, as populações braquíticas podem apresentar efeitos adversos quando sob seleção devido a efeitos adversos do gene $\mathrm{br}_{2}$. Um desses efeitos pode ser ocasionado pelo reduzido comprimento dos internódios das plantas braquíticas o que faz com que a emergência dos cabelos nas espigas seja mais dificil que o normal. Pode ser devido a isto que as formas braquíticas apresentem uma maior porcentagem de plantas estéreis que as normais (Castro, 1983). Este autor cita que as plantas braquíticas competem mais por luz entre as folhas que as formas normais. Estes efeitos podem ser influenciado negativamente a seleção para a prolificidade nas populações Piranão VD2B e Piranão VF1B quando submetidas ao método Seleção $S_{1}$.

A depressão por endogamia nas progênies oriundas do método Seleção $S_{1}$, pode ser visualizada pela redução dos outros parâmetros avaliados. Ocorreu redução na altura da planta (AP), altura da espiga (AE) e peso de espigas (PE) em todas as populações 
submetidas ao método (Tabela 8 e 9). As maiores reduções no peso de espigas ocorreram nas populações Piranão VF1B e Piranão VD2B, que passaram de 111,1 e 77,6 $\mathrm{g} /$ planta em $\mathrm{C}_{0}$ para 57,9 e 38,9 g/planta em $\mathrm{C}_{1}$, respectivamente, em 1999 e 131,2 e $129,7 \mathrm{~g} /$ planta em $\mathrm{C}_{0}$ para 68,1 e $61,9 \mathrm{~g} /$ planta em $\mathrm{C}_{1}$, respectivamente, em 2000. A menor redução ocorreu na população ESALQ-PR1, que apresentou peso de espigas de $76,4 \mathrm{~g} /$ planta em $\mathrm{C}_{0}$ e 55,6 g/planta em $\mathrm{C}_{1}$ em 1999. Esta população apresentou menor redução na produção de espigas porque foi oriunda de uma progênie de meios irmãos e, portanto, já apresentava elevada depressão por endogamia antes da seleção.

$O$ método Seleção $S_{1}$ necessita uma geração de recombinação, para o retorno da população à condição não endógama para a finalização do ciclo de seleção. Portanto, para a realização de um ciclo são necessárias três fases: $1^{\text {a}}$ ) obtenção das progênies, $2^{\mathrm{a}}$ ) avaliação das progênies e $3^{a}$ ) recombinação das progênies selecionadas (Figura 2). Como no método Seleção $S_{1}$ ocorre a avaliação fenotípica das espigas de plantas individuais, e não das progênies, o ciclo é completado em somente duas gerações.

$\mathrm{Na}$ estimação das médias das populações de primeiro ciclo $\left(\mathrm{C}_{1}\right)$ foram utilizadas as progênies $S_{1}$ e IG oriundas dos experimentos do segundo ciclo nos dois métodos intrapopulacionais, conforme esquema das Figuras 1 e 2 . Nestes experimentos foram incluídas as populações originais, e assim foram estimadas também as médias do ciclo $0\left(\mathrm{C}_{0}\right)$. As médias do ciclo denominado $\mathrm{C}_{01}$, correspondem às estimativas das populações oriundas do teste de progênies do primeiro ciclo e portanto, as populações, representadas pelas progênies, haviam sido submetidas à seleção massal para a prolificidade.

As populações $\mathrm{C}_{01}$ apresentam menor variabilidade do que as populações de referência devido a já terem sido submetidas a seleção. As progênies utilizadas para estimação da média do ciclo 1 no método Seleção $S_{1}$ ainda não haviam sido recombinadas, e portanto, apresentaram depressão por endogamia, como verificado nas Tabelas 8 e 9 . E somente após a recombinação, pode-se analisar perfeitamente as metodologias de seleção, sem a influência da endogamia. Contudo, optou-se pela 
comparação das populações da maneira apresentada nesse trabalho, devido à possibilidade de análise da depressão por endogamia e seus efeitos sobre a prolificidade.

Apesar da endogamia das progênies $S_{1}$, as populações Pichilingue, ITA-PR e HXI apresentaram médias do número de espigas por planta no ciclo 0 e ciclo 1 superiores às medias das progênies IG em 1999 (Tabelas 6 e 8). Contudo, as médias do peso de espigas e número de espigas por planta das testemunhas foram maiores nos ensaios das progênies $S_{1}$ do que nas progênies IG e as médias do estande e da altura das plantas das progênies $S_{1}$ foram menores do que nas progênies IG. Isto indica que houve menor competição entre plantas nos experimentos do método Seleção $S_{1}$.

Com a redução da densidade populacional, aumenta o número de espigas por planta devido ao aumento da disponibilidade de nutrientes e água para as plantas individuais (Jacobs \& Pearson, 1991; Thomison \& Jordan, 1995). Portanto, o menor estande e vigor das plantas pode ter reduzido a competição entre elas, contribuindo para o aumento da média do número de espigas por planta nas populações ITA-PR, Pichilingue e ESALQ-PR1 nos dois anos e HXL em 1999, submetidas ao método Seleção $S_{1}$. Apesar desta influência, pode-se considerar que o método Seleção $S_{1}$ foi eficiente para a seleção para a prolificidade, pois, mesmo com a depressão por endogamia afetando todos os outros caracteres, foi detectado uma prolificidade maior no ciclo 1 em relação ao ciclo 0 em quatro das seis populações avaliadas. Este é um indicativo de que a seleção para a prolificidade pode ser realizada com o método Seleção $S_{1}$

\subsection{Análise de variância e estimativa dos parâmetros genéticos}

\subsubsection{Primeiro ciclo}

Nas Tabelas 18 a 23 são apresentadas as análises de variância dos parâmetros avaliados no primeiro ciclo de seleção, dos métodos Seleção $S_{1}$ e Seleção IG. Ocorreram diferenças significativas entre progênies na maior parte das características nos 
experimentos. Os coeficientes de variação das progênies endogâmicas $\left(\mathrm{S}_{1}\right)$ foram superiores aos dos experimentos com as progênies IG na maioria das caracteristicas.

Os quadrados médios de progênies nos experimentos com as progênies endogâmicas foram superiores aos dos experimentos com as progênies IG para as características altura da planta, altura da espiga, estande, número de espigas, número de espigas por planta, comprimento e diâmetro de espigas. $\mathrm{O}$ inverso ocorreu com as características peso de espigas e peso de grãos. Isso demonstra que a variabilidade entre progênies endogâmicas é maior para a maior parte das características, enquanto que para a produção de grãos e espigas a variabilidade genética é maior entre progênies IG do que entre progênies $S_{1}$. Isto pode ser resultado do componente $D_{1}$, ou a covariância entre os efeitos médios dos genes e os efeitos de dominância, que pode ser negativo. No caso das populações analisadas neste trabalho, é provável que o componente D1 reduziu a variância entre progênies das progênies endogâmicas $S_{1}$ do peso de espigas e peso de grãos.

A variância genética entre progênies da prolificidade foi maior nas progênies $S_{1}$ em comparação com as progênies IG. Consequentemente, as estimativas de herdabilidade daquelas progênies foram maiores do que nas progênies IG, nos dois ciclos de seleção. Estes resultados confirmam as suposições teóricas e, portanto, a variância de progênies $S_{1}$ é maior do que a variância de progênies IG para a maior parte das características.

Contudo, a variância genética da produção de espigas foi maior nas progênies IG do que nas progênies $S_{1}$ em todas as populações e nos dois ciclos de seleção. $O$ aumento da variabilidade entre progênies com a endogamia é conseqüência da redistribuição da variância genética; uma vez que o componente entre médias das linhagens aumenta (Falconer \& Mackay, 1996). A variância entre progênies diminuiu no peso de espigas porque a variância entre progênies $S_{1}$ não é função somente dos componentes de variância da população de referência. A variância entre progênies é função também da covariância entre os efeitos médios dos alelos e os efeitos de dominância dos homozigotos $\left(\mathrm{D}_{1}\right)$ (Souza Júnior, 1989), que pode ser negativo e, 
portanto, reduzir a variabilidade entre progênies de autofecundação (Hallauer \& Miranda Filho, 1988), como aconteceu com as populações desse trabalho. Pelo fato de $D_{1}$ ser função direta do grau de dominância, pode ter pouca influência nos caracteres com base genética estritamente aditiva, como a prolificidade, mas pode afetar sensivelmente os caracteres que expressam dominância, como é o caso de produção de grãos em milho.

Na Tabela 10 são apresentadas as estimativa dos parâmetros genéticos e a herdabilidade do peso de espigas (PE), o peso de grãos (PG) e o número de espigas por planta (NEP) das populações submetidas aos métodos Seleção IG e Seleção $S_{1}$ avaliadas no primeiro ciclo de seleção.

A estimativa da variância de progênies e da variância fenotípica do número de espigas por planta (NEP) foi maior nas progênies $S_{1}$ do que nas progênies IG em todas as populações. No método Seleção $S_{1}$, a população Piranão VF1B apresentou a maior estimativa da variância de progênies e variância fenotípica do número de espigas por planta, de 0,05020 e 0,07689, respectivamente, e a população ESALQ-PR1 apresentou as menores variâncias, de 0,00800 e 0,01635 , respectivamente.

No método Seleção IG as maiores variâncias genéticas e fenotípicas foram obtidas pela população Piranão VF1B-P, de 0,02570 e 0,03854 , respectivamente, e a menores variâncias pela população ESALQ-PR1, de 0,00290 e 0,00831 , respectivamente. Os valores da variância de progênies das populações submetidas ao método Seleção IG foram bastante similares, com exceção da população ESALQ-PR1. $\mathrm{Na}$ suposição de ausência de dominância, tem-se $\sigma_{I G}^{2}=\frac{1}{2} \sigma_{A}^{2}$ e $\sigma_{S 1}^{2}=\sigma_{A}^{2}$, então é esperado que os valores da variância genética das progênies $S_{1}$ sejam duas vezes o valor da variância genética das progênies IG. Isto ocorreu no número de espigas por planta no primeiro ciclo.

Ao contrário da prolificidade, a variabilidade para o peso de espigas (PE) e peso de grãos (PG) foi maior no método Seleção IG do que no método Seleção $S_{1}$ (Tabela 10). As diferenças nas variâncias do peso de espigas entre os dois métodos foram bastante proeminentes em todas as populações, com exceção da população 
Pichilingue. A população Piranão VF1B-P apresentou a maior variância genética e fenotípica do peso de espigas no método Seleção IG, de 262,84019 e 381,0707, respectivamente, e a população Pichilingue as menores variâncias, de 90,7739 e 221,19563 , respectivamente. $\mathrm{O}$ peso de grãos (PG) apresentou a mesma tendência do peso de espigas.

No método Seleção $S_{1}$, a população Piranão VF1B apresentou as maiores variâncias genética e fenotípica da produção de espiga, de 146,525 e 186,748 e a população ESALQ-PR1 apresentou as menores variâncias, de 47,441 e 69,107, respectivamente. Os resultados de literatura são similares aos valores observados (Subandi \& Compton, 1974; Hallauer \& Miranda Filho,1988). Nesse trabalho, todas as estimativas de variância de irmãos germanos da produção de grãos foram maiores que os valores citados pelos autores acima e todas as estimativas da variância genética da produção de grãos das progênies $S_{1}$ foram inferiores aos relatados na literatura.

As médias do número de espigas por planta, peso de espigas e peso de grãos foram maiores no método Seleção IG do que no método Seleção $S_{1}$, devido a depressão por endogamia das progênies $S_{1}$. Somente após a seleção e o retorno à condição não endógama, é que as populações podem ser comparadas com respeito às médias das características de importância econômica e a eficiência da seleção para a produção de grãos nos dois métodos pode ser analisada.

A herdabilidade do número de espigas por planta, peso de espigas e peso de grãos foi maior no método Seleção $S_{1}$ que no método Seleção IG em todas as populações nos experimentos de primeiro ciclo (Tabela 10 ), com exceção do peso de espigas. Para o número de espigas por planta, no método Seleção $S_{1}$ a maior herdabilidade foi obtida pela população Pichilingue, de $74 \%$ e a menor pela população ESALQ-PR1, de 49\%. No método Seleção IG, os valores de herdabilidade do número de espigas por planta foram elevados, com exceção da população ESALQ-PR1. A maior herdabilidade no número de espigas por planta foi obtida pela população Piranão VF1B$P$, de $67 \%$ e a menor pela população ESALQ-PR 1, de $35 \%$. 
A herdabilidade do número de espigas por planta, da produção de espigas e da produção grãos foram similares em todas as populações no primeiro ciclo, com exceção da população ESALQ-PR1 em que a herdabilidade do número de espigas por planta foi inferior à da produção de espigas nos dois métodos intrapopulacionais.

A herdabilidade do peso de espigas ( $\mathrm{PE}$ ) e peso de grãos (PG) foi próxima ou acima de $60 \%$ em todas as populações e nas duas metodologias no primeiro ciclo de seleção, com exceção da população Pichilingue, no método Seleção IG. Estes valores são considerados elevados para as características (Hallauer \& Miranda Filho, 1988).

\subsubsection{Segundo ciclo}

As análises de variância das características avaliadas nas populações de segundo ciclo do método Seleção IG são apresentadas nas Tabelas 24 a 29 e do Seleção $S_{1}$ são apresentadas nas Tabelas 30 à 35 . Assim como no primeiro ciclo, o quadrado médio de progênies dos experimentos com as progênies endogâmicas $\left(\mathrm{S}_{1}\right)$ foi maior do que experimentos com as progênies IG para a maior parte das características nas populações, com exceção do peso de espigas e peso de grãos. $\mathrm{O}$ teste $\mathrm{F}$ mostrou significância para a variação entre progênies para a maior parte das características nas populações, indicando a existência de variabilidade entre as progênies.

Do mesmo como que nos experimentos do primeiro ciclo, os coeficientes de variação das características foram maiores nos experimentos com as progênies endogâmicas do que nos experimentos com as progênies IG. Isto indica que a endogamia reduziu a precisão experimental dos caracteres. $\mathrm{O}$ mesmo foi observado por Kassouf \& Miranda Filho (1986).

Nas Tabelas 11 e 12 são apresentados as estimativas da variância genética, variância fenotípica e a herdabilidade das populações de segundo ciclo, submetidas aos métodos Seleção IG e Seleção $S_{1}$, respectivamente. 
Igualmente ao primeiro ciclo, a variabilidade do número de espigas por planta (NEP) foi maior nas progênies $S_{1}$ do que nas progênies IG em todas as populações e o inverso é verificado para o peso de espigas (PE) e o peso de grãos (PG). Cada população apresentou distinta performance nos locais para a variância genética, fenotípica e herdabilidade. Como os locais são totalmente distintos com relação as características de solo e clima, este tipo de resposta era esperado e ratifica a escolha da análise por local em vez da análise conjunta dos dados.

No método Seleção IG, as populações HXI, Piranão VD2B em Piracicaba e Pichilingue e Piranão VF1B-P em Anhembi apresentaram as maiores estimativas de variância genética e variância fenotípica para o número de espigas por planta, todos eles próximos a 0,015 e 0,026, respectivamente. Estes valores são similares aos observados na literatura (Laible \& Dirks, 1968; Soares Filho, 1987; Miranda Filho \& Andrade ${ }^{4}$ ). A população Pichilingue em Piracicaba apresentou a menor estimativa de variância genética e fenotípica, de 0,00221 e 0,01085 espigas por planta, respectivamente.

Os valores da variância genética observados foram similares aos encontrados na literatura. Soares Filho (1987) estimou variância aditiva da prolificidade da população Piranão VD2B de 0,03750 e 0,00410 em dois anos. Neste trabalho obteve-se estimativas de variância genética entre progênies $S_{1}$ de 0,0258 no primeiro ciclo e de 0,01910 no segundo ciclo para a mesma população. Para progênies IG, obteve-se estimativas de variância genética de 0,01500 no primeiro ciclo e de 0,00881 e 0,01578 no segundo ciclo. Supondo ausência de dominância, $\sigma_{I G}^{2}=\frac{1}{2} \sigma_{A}^{2}$, a estimativa da variância aditiva seria: 0,03000 no primeiro ciclo e 0,01762 e 0,03156 no segundo ciclo.

Para a população Piranão VF1B, Soares Filho (1987) estimou variância aditiva de 0,0213 e 0,0209 em dois anos. Neste trabalho, foram obtidas estimativas de variância de progênies $S_{1}$ de 0,0502 no primeiro ciclo e de 0,02676 no segundo ciclo. A variância

\footnotetext{
${ }^{4}$ MIRANDA FILHO, J.B.; ANDRADE, J.A.C. (Departamento de Genética, ESALQ/USP). Quantitative traits in the maize population ESALQ-PB ${ }^{1}$ : parameters estimative. (No prelo).
} 
de progênies IG foi de 0,0134 no primeiro ciclo e de 0,00694 e 0,00442 no segundo ciclo. A estimativa da variância aditiva é de 0,0268 no primeiro ciclo e de 0,01388 e 0,00884 no segundo ciclo nos dois locais. Na população Piranão VF1B-P as estimativas da variância aditiva das progênies IG foi de 0,514 no primeiro ciclo e de 0,02736 e 0,01394 no segundo ciclo nos dois locais.

As estimativas de variância aditiva das populações Piranão no primeiro ciclo foram maiores que as estimativas no segundo ciclo. Contudo, apesar de ter ocorrido alguma discrepância entre as estimativas, estas não foram muito distantes das observadas anteriormente na literatura.

As estimativas de herdabilidade do número de espigas por planta das populações do método Seleção IG no segundo ciclo apresentaram valores bastante discrepantes. A amplitude de variação foi de $21 \%$ na população Piranão VF1B à $63 \%$ na população Piranão VD2B em Piracicaba. O número de espigas por planta apresentou herdabilidade inferior do peso de espigas (PE) em todas as populações e locais no segundo ciclo. No segundo ciclo as herdabilidades foram comparativamente menores que no primeiro ciclo no método Seleção IG.

A população ITA-PR apresentou a maior discrepância nas estimativas da herdabilidade entre os locais no método Seleção IG, com 26\% em Anhembi e 61\% em Piracicaba. Isto ocorreu devido a grande influência do ambiente na prolificidade. As menores herdabilidades foram obtidas pelas populações Piranão VF1B e ITA-PR em Anhembi, com $29 \%$ e $26 \%$, respectivamente, e Piranão VF1B e Pichilingue em Piracicaba, com $21 \%$ e $20 \%$, respectivamente. Apesar da baixa herdabilidade do número de espigas por planta destas populações, a herdabilidade do número de espigas (NE) foi elevada em todas as populações e locais. Portanto, o estande das parcelas pode estar influenciando os resultados do número de espigas por planta, isto porque a densidade populacional afeta o intervalo entre o florescimento masculino e feminino, o que tem grande influência sobre o número de espigas das plantas (Jacobs \& Pearson, 1991).

Portanto, a grande variação na herdabilidade das populações nos locais e os baixos valores encontrados pode ser resultado de alterações no estande das parcelas, o 
que provoca o aumento na variação no número de espigas por planta entre as parcelas $\mathrm{e}$ o conseqüente aumento do erro experimental e a redução da herdabilidade da prolificidade.

No segundo ciclo de seleção, no método Seleção $S_{1}$, a maior variância de progênies e fenotípica do número de espigas por planta foi da população ESALQ-PR1 de 0,05105 e 0,06760 em 1999 e de 0,04032 e 0,05935 em 2000, respectivamente, e as menores pela população Pichilingue, de 0,01325 e 0,03138 em 1999 e 0,0096 e 0,03446 em 2000, respectivamente (Tabela 12). A herdabilidade do número de espigas por planta na Seleção $S_{1}$ variou de $28 \%$ na população Pichilingue em 2000 a $76 \%$ na população ESALQ-PR1 em 1999. Para o peso de espigas a herdabilidade variou de $36 \%$ na população Piranão VF1B em 2000 a $91 \%$ na população ESALQ-PR1 em 1999. Assim como nas progênies IG, no método Seleção $S_{1}$ o número de espigas por planta apresentou menor herdabilidade do que o peso de espigas em todas as populações.

A variância de progênies e variância fenotípica da prolificidade foram menores no segundo ciclo em relação ao primeiro ciclo na maior parte das populações, nos dois métodos de seleção, indicando que a seleção reduziu a variabilidade da característica. Contudo, ocorreu o inverso com a variância de progênies e fenotípica da produção de espigas.

Na Figura 3 são apresentadas as médias das estimativas da herdabilidade dos dois ciclos de seleção, nos dois métodos intrapopulacionais. As estimativas de herdabilidade foram maiores no método Seleção $S_{1}$ do que no método Seleção IG. Isto ocorreu devido à maior variância de progênies nestas populações. Consequentemente, 0 ganho genético estimado destas progênies é maior que o ganho genético com progênies IG. No método Seleção IG, a maior estimativa foi da população HXL com herdabilidade de 59\% e no método Seleção S1 a maior estimativa foi da população ITA-PR, de 65\%.

Assim como os parâmetros genéticos, as estimativas de herdabilidade da prolificidade são grandemente influenciadas pelas condições ambientais em que a população é avaliada (Hallauer,1974; Hallauer e Miranda Filho, 1988; Guei e Wassom, 1992), o que explica a grande variação nos coeficientes de herdabilidade encontrados 
neste trabalho e na literatura. Hallauer (1974) observou uma variação de 0 a $77,5 \%$ nas estimativas da herdabilidade no cruzamento entre linhagens de milho com diferente número de espigas por planta, testadas em diferentes densidades populacionais. Isto ocorre porque o desenvolvimento das espigas depende de uma complexa interação de processos fisiológicos, cuja expressão depende grandemente das condições ambientais. Os principais eventos que determinam a prolificidade são o intervalo de florescimento masculino e o da primeira e segunda espiga. Quaisquer fatores ambientais que alterem estes eventos, incluindo a competição entre plantas ou estresse hídrico, por exemplo, tem grande influência no desenvolvimento da segunda espiga nas plantas.

\subsection{Ganho genético e resposta correlacionada}

$\mathrm{O}$ ganho genético $\left(\mathrm{G}_{\mathrm{s}}\right)$ esperado e realizado do número de espigas por planta (NEP) das populações submetidas aos métodos Seleção $I G$ e Seleção $S_{1}$ nos dois ciclos de seleção é apresentado na Tabela 13.

No primeiro ciclo, o $G_{\mathrm{s}}$ esperado foi maior no método Seleção $S_{1}$ do que no método Seleção IG em todas as populações. Nas populações ITA-PR, Pichilingue e Piranão VD2B, as estimativas de $G_{s}$ com o método Seleção $S_{1}$ ficaram próximas do dobro da estimativa do método Seleção IG. Isto é reflexo das maiores estimativas de herdabilidade daquelas progênies. As estimativas de $\mathrm{G}_{\mathrm{s}}$ no método Seleção $\mathrm{S} 1$ ficaram entre 13,13 e $16,74 \%$ por ciclo. No método Seleção IG as estimativas de $\mathrm{G}_{\mathrm{s}}$ ficaram entre 6,54 e $15,09 \%$ por ciclo.

No método Seleção IG o $\mathrm{G}_{\mathrm{s}}$ realizado na prolificidade no Ciclo 1 refletiu em grande parte o $\mathrm{G}_{\mathrm{s}}$ estimado. Na população Piranão VD2B, o $\mathrm{G}_{\mathrm{s}}$ foi de $11,81 \%$ e $12,42 \%$ em Anhembi e Piracicaba, respectivamente, enquanto o $\mathrm{G}_{\mathrm{s}}$ estimado ficou em 7,16\%. $O$ maior $\mathrm{G}_{\mathrm{s}}$ realizado ocorreu na população Piranão VF1B-P em Anhembi com 16,76\% e o menor $\mathrm{G}_{\mathrm{s}}$ ocorreu na população ITA-PR em Piracicaba, com 5,16\%. Portanto, o $\mathrm{G}_{\mathrm{s}}$ com o método Seleção IG foi elevado nos dois locais e em todas as populações. A média do $\mathrm{G}_{\mathrm{s}}$ realizado no ciclo 1 ficou em $10,58 \%$ no método Seleção IG. 
No segundo ciclo, o $\mathrm{G}_{\mathrm{s}}$ esperado com a Seleção IG também foi elevado para a maior parte das populações e locais, com exceção da população Piranão VF1B em Anhembi e Piracicaba, com estimativas de 1,76 e 3,83\%, respectivamente, e população Pichilingue em Piracicaba, que apresentou estimativa de $\mathrm{G}_{\mathrm{s}}$ de $2,85 \%$. Estas populações apresentaram estimativas inferiores às demais devido à menor variância genética, uma vez que a variância fenotípica se manteve similar à das outras populações.

A população Piranão VF1B-P mostrou estimativa de $\mathrm{G}_{\mathrm{s}}$ na prolificidade de $12,35 \%$ e 6,91\%; a população ITA-PR de 5,35\% e 11,15\%; a população Pichilingue de 9,74\% e 2,85\%; a população Piranão VD2B de $9,98 \%$ e $15,51 \%$, e a população HXL de $11,29 \%$ e 12,62\% em Anhembi e Piracicaba, respectivamente. Igualmente ao primeiro ciclo, estes valores são elevados e expressam a alta eficiência da metodologia para a seleção para a prolificidade.

As vantagens do método Seleção IG aqui proposto em relação ao original de Paterniani (1978) são:

1) A não necessidade de isolamento do campo de polinização, o que pode facilitar a operacionalização principalmente quando se trabalha com mais de uma população, como no presente caso,

2) Cruzamento controlado permite controle gamético para ambos os sexos, resultado em tamanho efetivo populacional $\left(\mathrm{N}_{\mathrm{e}}\right)$ teoricamente duas vezes maior, em comparação com amostragem completamente aleatória de gametas (Miranda Filho \& Vencovsky, 1978; Hallauer \& Miranda Filho, 1988);

3) Ao ganho da seleção massal para ambos os sexos é ainda adicionado o ganho genético do teste de progênies de irmãos germanos.

$\mathrm{O} \mathrm{G}_{\mathrm{s}}$ depois de cada ciclo de seleção, pode ser demonstrado como: $G_{S_{0}}=G_{S I G}+G_{S M}$, onde: $G_{S_{0}}=$ ganho genético observado; $G_{S I G}=$ ganho genético com o teste de irmãos germanos; $G_{S M}=$ ganho genético com a seleção massal. Contudo, o $\mathrm{G}_{s}$ com o teste de irmãos germanos é reduzido pela redução da variância de progênies 
$\left(\Delta_{\text {var }}\right)$, como resultado da seleção massal $G_{S I G_{0}}=G_{S G G}-\Delta_{\text {var }}$. A expressão se torna: $G_{S_{0}}=G_{S G}-\Delta_{\text {var }}+G_{S M}$. Mas o $\mathrm{G}_{\mathrm{s}}$ com a seleção massal é maior do que a perda causada na variabilidade $G_{S M}>\Delta_{\text {var }}$ e o ganho genético total é $G_{S_{0}}>G_{S G G}$, ou seja, o $G_{s}$ observado é maior ou equivalente ao o $\mathrm{G}_{\mathrm{s}}$ esperado pelo teste de irmãos germanos, porque a redução da variância de progênies é compensada pelo $G_{s}$ ocorrido com a seleção massal. Isto explica os elevados $\mathrm{G}_{\mathrm{s}}$ obtidos no método Seleção IG.

No método Seleção $S_{1}, o G_{s}$ realizado no primeiro ciclo foi inferior ao estimado em todas as populações. Como já comentado, isto ocorreu devido à depressão por endogamia que é característico das progênies endogâmicas $S_{1}$. Apesar disto, a população ITA-PR mostrou um $\mathrm{G}_{\mathrm{s}}$ de $9,18 \%$ em Anhembi, o que é bastante similar ao $\mathrm{G}_{\mathrm{s}}$ realizado no método seleção IG $(9,75 \%)$. A população $H X I$ mostrou um $\mathrm{G}_{\mathrm{s}}$ de $4,10 \%$ em Anhembi, bastante similar ao método seleção IG, de 5,57\%.

As populações Piranão VD2B e Piranão VF1B mostraram $G_{s}$ negativos nos dois anos em Anhembi. Em 1999 o $_{\mathrm{s}}$ foi de -12,38\% e -5,42\%, respectivamente, e em 2000 o ganhos foram de $-4,99 \%$ e $-1,27 \%$, respectivamente. A população HXI mostrou $\mathrm{G}_{\mathrm{s}}$ negativo em 2000 em Anhembi, de -7,50\%. Contudo, no ano anterior, a população aumentou a prolificidade em $4,10 \%$.

No segundo ciclo de seleção, $0 G_{s}$ esperado no método Seleção $S_{1}$ foi equivalente ao $\mathrm{G}_{\mathrm{s}}$ esperado no método Seleção IG na maioria das populações. A exceção foi a população Piranão VF1B que apresentou estimativas no método Seleção $S_{1}$ superiores as do método Seleção IG nos dois locais. Esta população obteve a maior estimativa de $\mathrm{G}_{\mathrm{s}}$ no método Seleção $\mathrm{S}_{1}$ de $14,61 \%$ em 1999. A menor estimativa foi da população Pichilingue em 2000, com 5,90\%.

No primeiro ciclo, a média do $\mathrm{G}_{\mathrm{s}}$ realizado no método Seleção IG foi maior que o $\mathrm{G}_{\mathrm{s}}$ esperado, de $10,58 \%$ e $9,41 \%$, respectivamente. A média do $\mathrm{G}_{\mathrm{s}}$ estimado no segundo ciclo foi de $8,61 \%$, valor este semelhante ao $\mathrm{G}_{\mathrm{s}}$ obtido no primeiro ciclo. Este método, portanto, foi bastante eficiente na seleção para a prolificidade. 
No método Seleção $S_{1} \circ G_{s}$ foi inferior ao esperado devido à depressão por endogamia ter afetado a expressão da prolificidade nas progênies endogâmicas $S_{1}$. Apesar desta influência, somente duas das seis populações avaliadas reduziram a prolificidade no ciclo 1 .

$\mathrm{Na}$ Tabela 14 são apresentadas as estimativas da correlação genética e fenotípica entre o número de espigas por planta (NEP) e a produção de espigas (PE) nos experimentos de avaliação das progênies IG e $\mathrm{S}_{1}$ do segundo ciclo de seleção, avaliados em Anhembi e Piracicaba.

As populações apresentaram valores distintos de correlação e os valores dos locais não foram similares na maioria das populações. A correlação genética no método Seleção IG variou de 0,20 a 0,92 e a correlação fenotípica variou de 0,21 a 0,64 . No método Seleção IG, a população ITA-PR apresentou correlação genética de 0,20 e 0,52 em Anhembi e Piracicaba, respectivamente. A maior correlação foi obtida na população Piranão VF1B em Anhembi, de 0,92. Contudo, em Piracicaba, a correlação genética da mesma população foi de 0,34 .

No método Seleção $S_{1}$ as maiores correlações genéticas e fenotípicas foram obtidas pela população ESALQ-PR1, de 0,86 e 0,79 em 1999 e de 0,82 e 0,74 em 2000, respectivamente, e as menores pela população Pichilingue, de 0,23 e 0,28 em 1999, em Anhembi.

A maior parte das estimativas de correlação observadas neste trabalho são inferiores aos encontrados na literatura (Robinson et al.,1951; Souza Júnior et al.,1985; Coors \& Mardones,1989). Maita e Coors (1996) obtiveram coeficiente de correlação fenotípica de 0,71 entre espigas por planta e produção de grãos por hectare ( $\mathrm{kg} / \mathrm{ha})$, na população ‘Golden Glow', na média de 20 ciclos de seleção massal para prolificidade.. Contudo, outros autores relataram coeficiente de correlação similares aos aqui observados (Hallauer e Miranda Filho, 1988). Guei \& Wassom (1992) observaram correlação genética e fenotípica de 0,43 e 0,69 em ambientes sob estresse hídrico, e de 0,36 e 0,47 em ambientes sem estresse hídrico no Pool Sequia e Pool 21, respectivamente. Segovia (1983) observou amplitudes de correlação simples entre peso 
de grãos e o número de espigas por planta de 0,0015 a 0,6171 em 8 ambientes, sendo que a média foi de 0,38 .

A média da correlação genética no método Seleção IG foi de 0,46 e 0,42 , em Anhembi e Piracicaba, respectivamente, e no método Seleção $S_{1}$ de 0,52 e 0,56 em 1999 e $2000 \mathrm{em}$ Anhembi, respectivamente, valores estes similares à estimativa dos autores citados. As médias da correlação fenotípica no método Seleção IG foram de 0,34 e 0,49 em Anhembi e Piracicaba, respectivamente, e no método Seleção $S_{1}$ de 0,52 e 0,55 em 1999 e 2000 em Anhembi. As médias no método Seleção $S_{1}$ foram superiores às do método Seleção IG devido às correlações elevadas observadas na população ESALQPR1 na Seleção $S_{1}$. Isto indica que progressos futuros na produção de grãos selecionando-se para a prolificidade serão elevados nessa população.

Apesar de todas as correlações serem positivas e significantes, há uma grande variação entre elas provavelmente devido à ocorrência de desvios nas estimativas dos componentes de variância do número de espigas por planta, o que reduz a correlação entre as características. Aliado a isto, a prolificidade apresentou distinta performance nos ambientes, o que pode ser visualizado nos valores discrepantes de herdabilidade no segundo ciclo de seleção (Tabela 12). Isto alterou a estimativa dos parâmetros genéticos e a correlação entre as características.

Na Tabela 15 é apresentada a resposta correlacionada $\left(\mathbf{R}_{\mathfrak{c}}\right)$ à seleção do número de espigas por planta sobre a produção de espigas das populações avaliadas em Anhembi e Piracicaba. A $R_{c}$ apresentou grande variação entre as populações e entre os locais nos dois métodos de seleção. No primeiro ciclo, no método Seleção IG, as populações Piranão VF1B-P, Piranão VF1B e Piranão VD2B, apresentaram $R_{c}$ estimada de 9,38 , 9,61 e 5,28\%, respectivamente, e as populações ITA-PR e Pichilingue não apresentaram $\mathbf{R}_{\mathrm{c}}$ à seleção para a prolificidade.

A amplitude de variação de $R_{c}$ realizada no primeiro ciclo no método Seleção IG, foi de $-3,64$ a $20,86 \%$. A $R_{c}$ realizada foi semelhante à esperada para as populações ITA-PR, Pichilingue e Piranão VD2B. A maior $R_{c}$ realizada foi da população Piranão 
VF1B no primeiro ciclo de seleção no método Seleção IG, em Anhembi e Piracicaba (20\%), que foi o dobro da $R_{c}$ esperada $(9,61 \%)$.

A população ITA-PR apresentou $R_{c}$ realizada negativa no Ciclo 1 nos dois locais, o que ratifica a $R_{c}$ estimada nula. A população Piranão VF1B-P apresentou $R_{c}$ realizada no primeiro ciclo de 3,84 e 0,82\% em Anhembi e Piracicaba, respectivamente, e a esperada de $9,38 \%$. A População $H X L$ apresentou $\mathbf{R}_{\mathbf{c}}$ bastante discrepante nos dois locais, de 15,42\% em Anhembi e 0,68\% em Piracicaba.

$A R_{c}$ esperada à seleção no segundo ciclo foi semelhante ao primeiro ciclo nas populações Pichelingue e Piranão VD2B. Na População ITA-PR e Piranão VF1B-P a $\mathbf{R}_{c}$ esperada no segundo ciclo foi superior à do primeiro ciclo e nas populações Piranão VF2B e HXL a $R_{c}$ esperada foi inferior à resposta observada no primeiro ciclo.

No primeiro ciclo de seleção, as $R_{c}$ estimadas nulas das populações ITA-PR e Pichilingue corresponderam a $\mathbf{R}_{c}$ realizadas negativas na população ITA-PR e baixas na população Pichilingue. Nas populações Piranão VF1B e Piranão VD2B as $R_{c}$ foram próximas ou superiores às respostas esperadas. As $R_{\mathrm{c}}$ realizadas no ciclo 1 ficaram bem abaixo do esperado somente na população Piranão VF1B-P. Portanto, a predição das $\mathbf{R}_{\mathbf{c}}$ esperadas foram condizentes com as $R_{c}$ observadas no primeiro ciclo de seleção em 4 das 5 populações avaliadas.

Apesar da grande amplitude de variação nas $R_{\mathbf{c}}$ das populações nos locais, as respostas esperadas no segundo ciclo de seleção no método Seleção IG são positivas e superiores a $2 \%$ em todas as populações e locais, com exceção da população Pichilingue em Anhembi, o que é similar ou superior ao observado por outros autores. Maita e Coors (1996) obtiveram aumento na produção de grãos de $1 \%$ por ciclo com a seleção para prolificidade. Mareck e Gardner (1979) obtiveram ganho na produtividade de 0,8 a 0,9\% por ano depois de 15 ciclos de seleção massal para a prolificidade. Singh et al. (1986) obtiveram ganhos de $4,5 \%$ por ciclo com seleção recorrente de irmãos germanos. Contudo, Segovia (1983) observou $R_{c}$ da prolificidade na produção de grãos de $15,43 \%$ na população Piranão VF1B e 1,56\% na População Piranão VD2B depois de quatro ciclos de seleção massal em ambos os sexos para a prolificidade. As $R_{c}$ realizadas neste 
trabalho no primeiro ciclo foram de 9,97 e 4,74 para a população Piranão VD2B e de 20,86 e 20,61 para a população Piranão VF1B nos dois anos, e portanto, valores superiores aos observados pelo autor acima.

Nove das doze estimativas das $R_{c}$ no segundo ciclo foram próximas ou superiores a $4 \%$. No primeiro ciclo, seis das doze $R_{c}$ realizadas foram próximas ou superiores a este valor. Estes resultados atestam o êxito da seleção para a produção de grãos selecionando-se para a prolificidade utilizando o método Seleção IG. Os valores negativos da $\mathbf{R}_{\mathbf{c}}$ observada na população ITA-PR no primeiro ciclo do método Seleção IG, é resultado da baixa correlação observada entre as características (Tabela 14).

No método Seleção $S_{1}$, não foram apresentadas as $R_{c}$ realizadas no primeiro ciclo porque estas foram todas negativas, devido a depressão por endogamia nas progênies endogâmicas $S_{1}$. As $R_{c}$ esperadas no segundo ciclo neste método foram todas superiores o método Seleção IG. Neste método a menor $R_{c}$ esperada foi da população Pichilingue em 1999, com 3\% de aumento na produção de grãos. $A$ maior $R_{c}$ no segundo ciclo no método Seleção $S_{1}$ foi da população ESALQ-PR1, com 21,77\% e 16,66\%, valores estes bastante elevados, comparando com os resultados de literatura. Isto é resultado das elevadas estimativas de variância entre progênies e da elevada correlação entre a produção de espigas e a prolificidade nesta população. Isto também ocorreu devido a reduzida média da produção de espigas da população ESALQ-PR1, devido ao seu baixo vigor, o que eleva o ganho genético da característica (Tabela 9).

Na Figura 4 é apresentada a evolução do número de espigas por planta com os ciclos de seleção no método Seleção IG nas seis populações avaliadas em Anhembi em 1987 e 1999. Nesse método, houve um progresso constante no número de espigas por planta com os ciclos de seleção em todas as populações. Os valores do ciclo $01\left(\mathrm{C}_{01}\right)$ foram intermediários aos do ciclo 0 e do ciclo 1 indicando que mesmo a seleção massal foi eficiente no aumento da média das populações. $O$ ganho combinado da seleção massal com o teste de progênies de irmãos germanos, é refletido nas médias do ciclo 1 , mostrando a eficiência da metodologia Seleção IG na seleção para a prolificidade. 
A população Piranão VD2B apresentou as menores médias da prolificidade em todos os ciclos e a população Piranão VF1B-P apresentou as maiores médias nos ciclos 1 e 2. Esta população apresentou o melhor desempenho por já ter sido submetida a prolificidade antes do início deste trabalho.

Na Figura 5 é apresentado a evolução do número de espigas por planta nas populações submetidas ao método Seleção $S_{1}$, avaliadas em Anhembi. Observa-se que a depressão por endogamia no ciclo 01 (C01) ou seja, após a autofecundação das plantas, foi bastante pronunciado nas populações ESALQ-PR1 e Piranão VD2B. As populações ITA-PR e Piranão VF1B apresentaram depressão moderada e a população HXI não apresentou depressão. A população Piranão VD2B também apresentou maior depressão no número de espigas por planta e no peso de espigas no método Seleção $\mathrm{S}_{1}$.

Contudo, após o primeiro ciclo, o efeito depressivo da endogamia foi menor em todas as populações. No ciclo 1 (C1) as populações ESALQ-PR1 e ITA-PR apresentaram crescimento do número de espigas (Figura 5), a população Pichilingue manteve e as populações Piranão VD2B, Piranão VF1B e HXI reduziram o número de espigas por planta em relação ao ciclo 0 . Contudo, maior alteração no número de espigas por planta ocorreu na população Piranão VD2B, que permaneceu com número de espigas inferior ao $\mathrm{C}_{0}$ até em $\mathrm{C}_{2}$, cuja estimativa não tem influência da endogamia. $\mathrm{Ou}$ seja, mesmo depois de dois ciclos de seleção, esta população não recuperou o número de espigas por planta presente no ciclo original.

No segundo ciclo de seleção as populações ITA-PR, ESALQ-PR1 e Piranão VD2B mantiveram os $\mathrm{G}_{\mathrm{s}}$ observados no primeiro ciclo (similar inclinação das retas) no método Seleção $S_{1}$, enquanto que a população Pichilingue teve uma $G_{s}$ esperada maior que no primeiro ciclo (Figura 5). A população ESALQ-PR1 apesar de ter apresentado redução acentuada no ciclo 01 , apresentou um $\mathrm{G}_{\mathrm{s}}$ considerável no ciclo 1 , provavelmente como resultado da maior herdabilidade da característica neste ciclo (Tabela 9). As progênies desta população apresentaram menor depressão por endogamia no ciclo 1 e a população mostrou um $\mathrm{G}_{\mathrm{s}}$ considerável no ciclo 2. Esta população recuperou nos ciclos 1 e 2 as perdas provocadas pela endogamia no ciclo 01 . 
Apesar dos efeitos negativos provocados pela endogamia na expressão da prolificidade, pode-se notar que não houve redução intensa das médias da prolificidade do ciclo 0 para o ciclo 1 na maior parte das populações, com exceção da população Piranão VD2B. Devido a isto, após o retorno da população à condição não endógama, é esperado que as médias da prolificidade no ciclo 1 sejam superiores ao do ciclo $0 \mathrm{em}$ todas as populações.

\subsection{Depressão por endogamia}

Na Figura 6 é apresentada a depressão por endogamia da prolificidade e da produção de espigas no ciclo 01 e ciclo 1, das populações avaliadas em Anhembi em 1997 e 1999. A prolificidade apresentou reduzida depressão por endogamia, quando comparada com a produção de grãos. A população Piranão VD2B apresentou a maior depressão na prolificidade nos dois ciclos, de 0,163 espigas por planta e 0,167 espigas por planta no primeiro e no segundo ciclo, respectivamente. As populações HXL e ITAPR não apresentaram depressão no segundo ciclo. A população Piranão VF1B apresentou redução de 0,09 e de 0,12 espigas por planta no primeiro e no segundo ciclo respectivamente. Na população Pichilingue, a depressão por endogamia foi de 0,05 espigas por planta nos dois ciclos de seleção.

Nas populações deste trabalho ocorreram valores de depressão por endogamia na prolificidade de 0 a $-16,8 \%$. A depressão por endogamia da prolificidade não é perfeitamente previsível nas populações de milho. Gama et al. (1985) não observaram efeito da endogamia na prolificidade em gerações avançadas de híbridos de milho. Ao passo que Packer (1998) observou endogamia de até 15,97\% em uma população com alto teor de óleo. Hallauer \& Miranda Filho (1988) mostraram depressão por endogamia $-0,02$ espigas por parcela na população BSSS. Nass \& Miranda Filho (1995) obtiveram valores de até $41 \%$ de depressão em populações semi-exóticas.

Segundo Falconer \& Mackay (1996), o valor médio da população sob endogamia é $M_{F}=M_{0}-2 F \sum d \overline{p q}$, para a soma de todos os locos, sendo que $M_{F}$ é a 
média da população com endogamia, $M_{0}$ é a média da população antes da endogamia; d é o efeito de dominância intra loco; p e q são as frequências alélicas. Então, a mudança no valor médio da população sob endogamia é conseqüência da dominância dos locos que governam a característica e a mudança ocorrerá na direção dos alelos recessivos. Como a prolificidade apresenta reduzido efeito de dominância, segundo dados de literatura (Laible \& Dirks, 1968; Sorrells et al., 1979), a característica apresenta reduzida depressão por endogamia na maior parte das populações estudadas neste trabalho.

Para a produção de espigas, a endogamia foi elevada em todas as populações no ciclo 0, com amplitude de variação de $39 \%$ a $69 \%$. A população Piranão VD2B apresentou a maior endogamia neste ciclo. No ciclo 1 houve uma redução na endogamia em relação ao ciclo 0 , apesar das populações terem apresentado uma depressão próxima a $50 \mathrm{~g}$ /planta. Os valores de depressão observados são equivalentes aos citados por Hallauer \& Miranda Filho (1988), que estimaram, a partir de dados de literatura, estimativas médias de depressão de $57,58 \mathrm{~g} /$ planta com $50 \%$ de homozigose.

Houve uma tendência de redução da endogamia com os ciclos de seleção em todas as populações, com exceção da população Piranão VF1B. Isto ocorreu porque o choque endogâmico provoca a expressão dos genes deletérios, que ocorrem em homozigose, e as plantas que os expressam são descartadas. Há pois uma "limpeza" na carga genética das populações e depressão por endogamia tende a se reduzir com os ciclos de seleção.

\subsection{Análise conjunta dos experimentos de segundo ciclo}

Nas Tabelas 36 a 41 são apresentadas as análises de variância conjunta dos experimentos de avaliação das progênies IG das populações de segundo ciclo de seleção. Como já comentado anteriormente, o objetivo da apresentação da análise conjunta é somente a análise da interação genótipo $\mathrm{x}$ ambiente da prolificidade $\mathrm{e}$ outras características de interesse. 
$\mathrm{O}$ teste $\mathrm{F}$ mostrou significância para a variação entre progênies para todos os caracteres em todas as populações, indicando que há variabilidade genética nas populações para as características avaliadas.

Ocorreu interação progênies $\mathrm{x}$ locais significativa para o número de espigas por planta em todas as populações, com exceção de Piranão VF1B. Para o número de espigas da parcela, ocorreu interação significativa somente para a população Piranão VD2B (Tabela 41). Portanto, a influência distinta dos ambientes sobre as progênies parece ser maior sobre o número de espigas por planta do que sobre o número de espigas da parcela. Esta resposta pode ser resultado da influência do estande na prolificidade nos distintos ambientes.

Ocorreu diferença significativa entre locais em todas as populações para o número de espigas da parcela, com exceção da população Piranão VF1B-P. Para o número de espigas por planta, ocorreu diferença significativa entres os locais somente para as populações Pichilingue e ITA-PR, ou seja, as três populações Piranão não apresentaram diferenças significativas entre os locais. Estas três populações também não apresentaram diferenças significativas entre locais para a altura da planta e altura da espiga. Aliado a isto, populações Piranão VF1B e Piranão VF1B-P não apresentaram interação genótipo $\mathrm{x}$ locais para o peso de espigas e apresentaram as maiores médias do número de espigas por planta nos dois locais no ciclo 1 (Tabelas 6 e 7).

Portanto, as populações Piranão VF1B e Piranão VF1B-P apresentaram um performance similar nos dois ambientes para a prolificidade, produção de espigas e altura da planta e um maior potencial prolífico quando comparado com as outras populações. Isto pode indicar que estas populações apresentam um desempenho mais estável em distintos ambientes, o que pode estar associado a um maior número de espigas por planta.

A população Piranão VD2B apresentou reduzida média do número de espigas por planta nos dois locais no ciclo 1. Portanto, apesar desta população ter mostrado um ganho genético considerável no método Seleção IG (Tabela 11), o desempenho prolífico ainda deixa a desejar. Como a população Piranão VD2B apresentou ganho genético 
observado negativo no método Seleção $S_{1}$ e elevada depressão por endogamia nos dois ciclos, pode-se inferir que esta população não tem potencial de melhoramento para a prolificidade.

Como houve interação progênie $\mathrm{x}$ local significativas para a maior parte das características, os ambientes são totalmente distintos e uma análise em separado dos materiais em cada ambiente seria mais vantajoso para a seleção, não só para a prolificidade, mas para as outras características de interesse.

As análises de variância conjunta dos experimentos de avaliação das progênies autofecundadas $\left(S_{1}\right)$ são apresentadas nas Tabelas 42 a 47 . $O$ teste $F$ mostrou significância para a variação entre progênies para todas os parâmetros em todas as populações, indicando que há variabilidade entre as progênies endogâmicas das populações para as características.

O coeficiente de variação da análise conjunta dos experimentos de avaliação das progênies $S_{1}$ foram superiores aos coeficientes de variação dos experimentos com as progênies IG, indicando que a endogamia afetou negativamente a precisão ambiental. Isto também foi observado em outros trabalhos (Kassouf \& Miranda Filho, 1984).

Para $\mathrm{o}$ número de espigas por planta a interação progênies $\mathrm{x}$ anos foi significativa nas populações HXI, ITA-PR e ESALQ-PR1 e para o número de espigas na parcela foi significativa nas populações HXI, ITA-PR, Piranão VF1B e ESALQPR1. Para a altura da planta, ocorreu interação ano $x$ progênies significativa nas populações Piranão VF1B e ITA-PR e para a produção de espigas para todas as populações, menos para a população Pichilingue. Para o estande ocorreu interação significativa para todas as populações, menos a população ITA-PR.

Ocorreu diferença significativa entre anos no número de espigas por planta nas populações HXL, ITA-PR, Pichilingue e Piranão VD2B. Para o número de espigas da parcela ocorreram diferenças significativas entre anos nas populações HXL, Pichilingue, Piranão VF1B e ESALQ-PR1. Para produção de espigas ocorreram diferenças significativas entre anos em todas as populações, com exceção da população HXL. 
Portanto, ocorreram diferenças significativas no desempenho dos progênies $S_{1}$ das populações entre os anos para as características estudadas. Para a prolificidade, as progênies $S_{1}$ das populações Piranão VD2B, Piranão VF1B e Pichilingue não apresentaram interação progênies $\mathrm{x}$ anos, ou seja, não apresentaram comportamento diferencial nos dois anos. A população Piranão VF1B, também não apresentou diferença significativa entre anos. Portanto, as progênies desta população apresentaram desempenho similar nos dois anos de estudo.

Portanto, a prolificidade apresentou performance similar nos ambientes estudados nas populações Piranão VD2B e Piranão VF1B, tanto para as progênies de autofecundação quanto para as progênies IG.

\subsection{Dados de espiga das progênies}

Os resultados das avaliações do comprimento, diâmetro, peso de espiga e peso de grãos da primeira e segunda espiga obtidas no método intrapopulacional Seleção $S_{1}$ no primeiro ciclo são apresentados na Tabela 16. São também mostrados o quociente entre os dados da segunda e da primeira espiga, das quatro características (RCE, RDE, RPE e RPG). Com base nestes quocientes foram selecionadas as 30 progênies superiores de cada população para recombinação e formação das populações de primeiro ciclo de seleção.

A principais características levadas em consideração para a seleção das progênies foram os índices de prolificidade, ou seja, o quociente de peso de grãos (RPG) e peso de espiga (RPE).

Ocorreram valores máximos de quocientes entre peso de grãos na segunda e na primeira espiga (RPG) e peso de espigas (RPE) maiores que um em várias plantas das populações. Ou seja, o peso de grãos na segunda espiga foi maior que o peso de grãos da primeira espiga. Os exemplos extremos ocorreram na população ITA-PR que apresentou valor máximo do quociente de peso de grãos igual a 45 e na população Pichilingue com valor máximo igual a 40. Isto não era esperado, pois, o milho apresenta dominância 
apical, ou seja, a supressão do desenvolvimento das espigas inferiores pela espiga superior (Phillips, 1975; Sorrells et al., 1978; Motto \& Moll, 1983; Pinthus \& Belcher, 1994). Ou seja, a primeira espiga se desenvolve primeiro e tem maior potencial de produção.

Contudo, algumas plantas apresentaram produção de grãos maior nas segundas espigas devido à forma de polinização das plantas. Nos esquemas de Seleção $S_{1} e$ Seleção IG, tanto as primeiras quanto as segundas espigas foram protegidas antes da emissão da barba. As polinizações foram realizadas na segunda espiga e as primeiras espigas foram desprotegidas um dia após a polinização (Paterniani, 1978), para favorecer o desenvolvimento das segundas espigas. Como normalmente o intervalo entre o começo da emissão do pólen e da emissão da barba da segunda espiga é grande, quando se descobriu a primeira espiga o pólen disponível nas populações era reduzido. Isto não permitiu uma polinização adequada destas espigas, principalmente das plantas com florescimento mais tardio. Por isso, as plantas com maior quociente de peso de grãos podem não ser as mais prolíficas, mas sim as que não receberam pólen suficiente na primeira espiga.

Contudo, o comprimento de espigas é uma caracteristica que não apresenta interferência da polinização, pois, mesmo com reduzida quantidade de grãos, o tamanho do sabugo não se altera, refletindo o potencial do número de grãos. 0 quociente do comprimento de espiga, portanto, nesta circunstância, seria mais apropriado para medida do grau de prolificidade, ou do potencial da segunda espiga. Este quociente apresentou pouca amplitude de variação nas populações, quando comparado com o peso de grãos e o peso de espigas (Tabela 16), evidenciando sua utilidade na seleção.

A população ITA-PR apresentou a maior amplitude de variação do quociente de peso de grãos, provavelmente devido ao maior ciclo desta população. Esta população é a mais prolífica das populações deste trabalho, apresentando plantas com até 4 espigas quando em plantios em baixa densidade.

Na Tabela 17 são apresentados as médias, o desvio padrão e os valores mínimos e máximos dos dados de espiga das progênies de autofecundação e progênies 
IG no segundo ciclo de seleção. As progênies $S_{1}$ apresentaram maiores médias de comprimento da primeira espiga (CE1) do que as progênies IG. O mesmo ocorreu com o diâmetro das primeiras espigas (DE1). Isto se refletiu no peso de grãos destas espigas (PG1), que foram maiores nas progênies $S_{1}$ do que nas progênies IG. Ocorreu o inverso com o comprimento das segundas espigas (CE2), onde as progênies IG apresentaram maiores médias do que as progênies $S_{1}$. Esta tendência não se manteve para a média do diâmetro e do peso de grãos das segundas espigas (DE2 e PG2).

Todos os índices de prolificidade (RCE, RDE e RPG) foram maiores nas progênies IG do que nas progênies $S_{1}$. Como o tamanho e produção das segundas espigas reflete o potencial prolífico das plantas, o maior tamanho das segundas espigas nas progênies demostra o maior potencial prolífico das progênies IG em relação às progênies $S_{1}$. Portanto, provavelmente, o método Seleção $I G$ foi mais eficiente na seleção para a prolificidade do que o método Seleção $S_{1}$.

Na Figura 7 são apresentados as médias do comprimento, diâmetro e peso de grãos das segundas espigas das plantas selecionadas no método Seleção $S_{1}$, nos dois ciclos de seleção. Ocorreu o aumento do comprimento, diâmetro e peso de grãos das segundas espigas de todas as populações com a seleção. Devido à dominância apical, é necessário que se reduza a influência da espiga superior sobre as espigas inferiores para assim, aumentar o número de espigas por planta (Sorrells et al., 1978; Pinthus \& Belcher, 1994). Isto indica que a metodologia Seleção $S_{1}$ aqui avaliada também foi eficiente no aumento do tamanho e potencial produtivo das segundas espigas.

\subsection{Considerações Gerais}

Os métodos Seleção IG e Seleção $S_{1}$ foram eficientes na seleção para a prolificidade nas populações avaliadas nesse trabalho, com exceção do método Seleção $S_{1}$ na população Piranão VD2B e Piranão VF1B. No método Seleção IG o aumento da prolificidade das populações foi acompanhado do aumento da produção de nos dois ciclos de seleção e nos dois locais. As respostas correlacionadas realizadas da 
prolificidade sobre a produção de grãos foram consistentes com as esperadas em quatro das cinco populações .

No método Seleção $S_{1}$, quatro das seis populações apresentaram aumento na prolificidade com a seleção. Isto ocorreu porque a prolificidade apresentou baixa depressão por endogamia, como resultado provavelmente, do baixo nível de dominância da característica nas populações. A depressão por endogamia foi maior na população Piranão VD2B e, devido a isto, esta população não apresentou resposta à seleção para a prolificidade nos dois ciclos seletivos com o método Seleção $S_{1}$.

A ausência de resposta à seleção pela população Piranão VD2B pode ter duas causas: 1) a ocorrência da endogamia acentuada como reflexo da redução drástica da variabilidade; 2) o efeito adverso provocado pelo gene $b r_{2}$. Não houve redução na variância genética e fenotípica da população Piranão VD2B do primeiro para o segundo ciclo de seleção, e esta não foi discrepante das outras populações, o que indica que a variabilidade não foi comprometida em grande extensão. $O$ nível de dominância da prolificidade parece ser o mesmo que nas outras populações, pois as variâncias genéticas e fenotípicas são similares.

A depressão por endogamia é função direta do grau de dominância do caráter, do coeficiente de endogamia (porcentagem dos locus em homozigose) e das freqüências gênicas da população (ou do nível de melhoramento da população). Muitos autores encontraram baixos níveis de dominância no número de espigas por planta Apesar das progênies $S_{1}$ não estimarem diretamente a variância genética aditiva, as observações indicam que esta foi mais expressiva do que a variância genética dominante nas populações aqui estudadas, uma vez que a prolificidade apresentou reduzida depressão por endogamia na maior parte das populações.

Como foram utilizadas as progênies $S_{1}$ para a estimação das médias das populações nos ciclos de seleção do método Seleção $S_{1}$, não foi possível avaliar adequadamente o impacto da seleção para a prolificidade sobre a produção de grãos e os outros caracteres das plantas neste método. Mas mesmo com a depressão por endogamia, as médias do número de espigas por planta no ciclo 1 foram superiores ao 
ciclo 0 . Ou seja, a prolificidade apresentou baixa depressão por endogamia, sendo que esta foi menor no ciclo 2. As populações ITA-PR e HXI não apresentaram depressão no ciclo 1. A população Piranão VD2B apresentou elevada depressão por endogamia nos dois ciclos.

No método Seleção $S_{1}$ é realizado seleção fenotípica em duas fases: no momento da obtenção das progênies e na seleção das espigas polinizadas. Após estas fases, as melhores progênies são recombinadas. Portanto, são necessárias duas gerações para a finalização de um ciclo de seleção. No método Seleção $S_{1}$, há necessidade da coincidência do florescimento masculino e da segunda espiga da mesma planta. E como o espaçamento utilizado para a obtenção das progênies deve ser o dobro do usual para favorecer a expressão da prolificidade, será necessário uma grande área experimental para a obtenção das progênies no método Seleção $S_{1}$. Se as populações apresentarem um nível de prolificidade inicial reduzido (abaixo de 0,90 espigas/planta), o tamanho da área experimental deve ser maior que o dobro de uma área de polinização normal, para que seja possivel a obtenção de uma quantidade suficiente de progênies $S_{1}$. Isto pode encarecer o processo de melhoramento para a característica.

Este método foi inicialmente realizado por Sprague \& Brimhall (1950), que realizaram a seleção para o aumento no conteúdo de óleo nas sementes de milho com a autofecundação das plantas e a recombinação das progênies $S_{1}$ selecionadas. Este método, denominado série recorrente, foi eficiente para o aumento do conteúdo de óleo nas sementes e possui a vantagem do controle parental absoluto dos indivíduos selecionados, uma vez que a autofecundação garante a perpetuação dos genes da planta selecionada.

Nesse método, as progênies $S_{1}$ são obtidas somente para a perpetuação das plantas selecionadas, uma vez que não envolve o teste de progênies. Portanto, a endogamia não interfere no processo de seleção. Contudo, caso as progênies apresentem acentuada depressão por endogamia, podem ocorrer desequilíbrios no momento da recombinação. Com a presença de acentuada depressão por endogamia nas progênies, estas podem possuir baixo vigor e quaisquer alterações ambientais, mesmo que não 
intensas, como deficiências hídricas ou nutricionais, podem afetar a sobrevivência e a produção das progênies menos vigorosas. Consequentemente, pode ocorrer uma recombinação desbalanceada dos genótipos selecionados, sendo aqueles mais vigorosos, os mais representados na população melhorada. Valois \& Miranda Filho (1984) observaram que a endogamia pode afetar a recombinação das progênies selecionadas quando as progênies apresentam elevada depressão por endogamia. Devido a este efeito indireto, o ganho genético com a utilização da endogamia pode ser menor do que o esperado.

No método Seleção IG a seleção também é realizada em duas fases: seleção massal em ambos os sexos no momento da obtenção das progênies e seleção pelo teste de progênies. Um ciclo é completado em duas gerações, pois a recombinação das progênies selecionadas ocorre juntamente com a obtenção das progênies do próximo ciclo de seleção. No método Seleção IG, as plantas prolíficas são polinizadas por outras plantas prolíficas da mesma população e, portanto, o número de progênies obtidas em uma população de baixa prolificidade é normalmente maior (aproximadamente o dobro) do que no método Seleção $S_{1}$. Neste método, é necessário o plantio de lotes de polinização com espaçamento maior que o usual para favorecer a expressão das plantas prolíficas, contudo, o número provável de progênies obtidas é suficiente para a realização do teste de progênies. Portanto, neste método, é necessária uma área de polinização o dobro da usual para a obtenção das progênies e áreas experimentais para a instalação dos experimentos de teste de progênies em dois ou mais locais. Portanto, neste método os gastos com o processo de melhoramento podem superar os gastos com a utilização do método Seleção S1. Devido a utilização somente de plantas prolíficas no momento da polinização, muitas vezes as plantas doadoras de pólen apresentam plantas com espigas no momento da polinização, mas a segunda pode não se desenvolver. Portanto, as plantas utilizadas na obtenção das progênies de irmãos germanos podem não ser realmente prolíficas, o que reduz os ganhos esperados. Isto provavelmente não ocorreu porque o ganho observado foi equivalente ao esperado na maior parte das populações. 
Contudo, não é possivel uma comparação estrita entre os dois métodos em termos de ganho genético, porque o método Seleção IG envolve, além da seleção massal em ambos os sexos, o teste de progênies com o emprego de irmãos germanos, o que produz ganhos superiores quando comparado somente com a seleção massal para ambos os sexos utilizado no método Seleção $S_{1}$. Os ganhos com o teste de progênies são maiores porque são baseados na performance média das progênies de plantas selecionadas, que são avaliadas em experimentos com repetições em vários locais. Isto faz com que a influência ambiental sobre a seleção e a interação genótipo $\mathrm{x}$ ambiente sejam menores, aumentado a eficiência da seleção. A seleção massal é normalmente realizada para a seleção de caracteres de baixa herdabilidade e para o aumento da adaptação das populações a ambientes específicos.

O objetivo do presente trabalho foi analisar a seleção para a prolificidade. Contudo, é importante a análise da relação desta com a produção de grãos tendo em vista que a produção de grãos normalmente é a característica de maior interesse no melhoramento. Para a seleção para a prolificidade, a maior parte dos trabalhos realizados até então utilizaram variantes da seleção massal. Contudo, muitos trabalhos de pesquisa indicam que a característica apresenta expressão grandemente influenciada pelo ambiente, com valores observados de herdabilidade entre 0 a $100 \%$, sendo que esta influência depende do genótipo estudado. Devido a isto, muitas vezes a seleção massal para a prolificidade pode não produzir os resultados esperados.

Por outro lado, a seleção indireta para uma característica, selecionando-se por uma característica secundária, é mais eficiente que a seleção direta somente se a característica secundária tem maior herdabilidade que a primária e a correlação genética entre as duas é alta. Contudo, muitos trabalhos mostram valores variáveis de correlação desta com a produção de grãos, apesar de normalmente a prolificidade apresentar altas correlações com a produção. Como a resposta correlacionada da prolificidade na produção de grãos é função direta da covariância entre as duas características, o ganho na produção de grãos pode ser comprometido se o ambiente influenciar sobremaneira a covariância entre as características. No caso deste trabalho, a maior parte das estimativas 
de correlação entre a produção de grãos e a prolificidade não foram elevadas. Ao mesmo tempo, a prolificidade apresentou estimativas de herdabilidade variáveis nos ambientes de estudo. Portanto, baseando-se nestes parâmetros, a seleção direta para a produção de grãos poderia produzir melhores resultados do que a seleção indireta através da prolificidade.

Contudo, a vantagem da seleção para a prolificidade não está somente no aumento da produção de grãos, mas também no aumento da estabilidade de produção e aumento das respostas em ambientes de cultivo com estresse (hídrico, competição por nutrientes ou de alta densidade populacional). Apesar deste tipo de reposta não ser completamente previsível, uma vez que há dependência da resposta do genótipo nos locais específicos de estudo, um grande volume de trabalhos mostram que esta tendência se mantém no milho. $\mathrm{O}$ próprio aumento do número de espigas por planta verificado nos híbridos e linhagens modernos quando comparado com os antigos, atestam que a prolificidade é estritamente relacionada com a produtividade na maior parte dos germoplasmas de milho. Pode-se, portanto, aumentar a eficiência da seleção para a produção de grãos através da consideração da prolificidade, se esta não produzir efeitos adversos nas populações.

A seleção para a prolificidade não provocou efeitos adversos nas populações estudadas. $O$ melhoramento de cultivares no milho envolve a seleção para maior produção de grãos, precocidade, baixa altura da planta e da espiga. Isso porque plantas mais baixas apresentam maior potencial de responder a aplicação de fertilizantes sem ocorrer o acamamento. Neste trabalho, a seleção para a prolificidade reduziu a altura da planta e a posição da espiga na planta, provavelmente devido a redução do ciclo das populações. A seleção para prolificidade foi eficiente no aumento do comprimento, diâmetro e produção de grãos da segunda espiga em todas as populações, indicando a redução da dominância apical com a seleção nas populações. Provavelmente, a seleção provocou alteração no balanço hormonal que regula dominância apical e a prolificidade nas plantas. Apesar de ter ocorrido alteração nos índices de espiga nos dois métodos, estes foram maiores no método Seleção IG. 
As populações Piranão VF1B, Piranão VF1B-P e Piranão VD2B apresentaram maior estabilidade na produção de espigas, número de espigas por planta e altura da planta, e as duas primeiras apresentaram as maiores médias do número de espias por planta nos dois locais.

Das populações avaliadas neste trabalho, a população Piranão VD2B apresentou o menor potencial prolifico e de seleção para a prolificidade. 


\section{CONCLUSÓES}

Nas condições do presente trabalho, a análise dos resultados permitem tirar as seguintes conclusões:

Os dois métodos intrapopulacionais testados foram eficientes no aumento da prolificidade das populações;

路 Houve um ganho genético de $10,58 \%$ e $8,61 \%$ no primeiro e no segundo ciclo respectivamente, no método Seleção IG e de $10,86 \%$ no segundo ciclo no método Seleção $S_{1}$;

D.s. Ocorreu uma razoável predição da resposta correlacionada da prolificidade no aumento da produção de grãos. A média do aumento da produção de grãos foi de $6,27 \%$ no método Seleção IG;

A prolificidade apresentou reduzida depressão por endogamia em todas as populações, com exceção da população Piranão VD2B;

Bà Houve tendência de redução da altura da planta, da posição relativa da espiga na planta e da média do comprimento e diâmetro das espigas com a seleção para a prolificidade;

Ocorreu aumento no comprimento, diâmetro e peso das segundas espigas com a seleção nos dois métodos;

S Seleção $S_{1}$, devido à utilização da endogamia, pode não proporcionar ganhos substanciais na produção de grãos com a seleção para a prolificidade; 
O método Seleção IG devido à combinação da seleção massal em ambos os sexos com a seleção pelo teste de progênies, apresenta-se com grande potencial para o melhoramento da prolificidade e da produção de grãos nas populações de milho. 
TABELAS 
Tabela 6. Médias do Ciclo $0\left(\mathrm{C}_{0}\right)$, Ciclo $1\left(\mathrm{C}_{1}\right)$ e testemunha das populações de milho submetidas ao método Seleção IG. Anhembi (SP), 1999.

\begin{tabular}{|c|c|c|c|c|c|c|c|c|}
\hline Populações & & $\mathbf{A P}$ & $\mathbf{A E}$ & PRE & ST & $\mathbf{P E}$ & NE & NEP \\
\hline \multirow[t]{4}{*}{ Piranão VF1B-P } & Test & 209 & 123 & 0,590 & 18,55 & 142,2 & 21,82 & 1,181 \\
\hline & $\mathrm{C}_{0}$ & 220 & 131 & 0,592 & 17,58 & 101,5 & 18,52 & 1,056 \\
\hline & $\mathrm{C}_{01}^{\dagger}$ & 213 & 124 & 0,582 & 15,57 & 113,1 & 17,49 & 1,123 \\
\hline & $\mathrm{C}_{1}$ & 219 & 131 & 0,600 & 16,24 & 105,4 & 19,71 & 1,233 \\
\hline \multirow[t]{4}{*}{ Piranão VF1B } & Test & 212 & 128 & 0,602 & 18,38 & 140,6 & 21,04 & 1,152 \\
\hline & $\mathrm{C}_{0}$ & 223 & 132 & 0,590 & 13,74 & 82,9 & 15,17 & 1,096 \\
\hline & $\mathrm{C}_{01}$ & 201 & 116 & 0,577 & 15,16 & 80,5 & 17,15 & 1,131 \\
\hline & $\mathrm{C}_{1}$ & 228 & 142 & 0,620 & 16,74 & 100,2 & 19,76 & 1,206 \\
\hline \multirow[t]{4}{*}{ ITA-PR } & Test & 211 & 124 & 0,586 & 18,61 & 129,4 & 20,00 & 1,095 \\
\hline & $\mathrm{C}_{0}$ & 228 & 134 & 0,588 & 18,61 & 106,4 & 19,64 & 1,062 \\
\hline & $\mathrm{C}_{01}$ & 227 & 131 & 0,577 & 17,14 & 82,7 & 18,67 & 1,089 \\
\hline & $\mathrm{C}_{1}$ & 225 & 134 & 0,597 & 17,40 & 105,6 & 19,86 & 1,165 \\
\hline \multirow[t]{4}{*}{ Pichilingue } & Test & 207 & 120 & 0,579 & 18,83 & 137,8 & 21,86 & 1,170 \\
\hline & $\mathrm{C}_{0}$ & 202 & 112 & 0,553 & 18,97 & 102,8 & 19,38 & 1,027 \\
\hline & $\mathrm{C}_{01}$ & 190 & 96 & 0,505 & 15,76 & 97,6 & 18,16 & 1,152 \\
\hline & $\mathrm{C}_{1}$ & 200 & 108 & 0,539 & 16,26 & 104,9 & 18,97 & 1,194 \\
\hline \multirow[t]{4}{*}{ Piranão VD2B } & Test & 195 & 113 & 0,577 & 17,95 & 120,6 & 20,57 & 1,155 \\
\hline & $\mathrm{C}_{0}$ & 193 & 108 & 0,557 & 18,05 & 87,7 & 17,79 & 0,991 \\
\hline & $\mathrm{C}_{01}$ & 172 & 99 & 0,576 & 15,06 & 82,0 & 15,78 & 1,048 \\
\hline & $\mathrm{C}_{1}$ & 190 & 106 & 0,558 & 16,47 & 96,5 & 18,06 & 1,108 \\
\hline \multirow[t]{4}{*}{$\overline{\mathrm{HXI}}$} & Test & 198 & 114 & 0,579 & 19,45 & 135,1 & 22,36 & 1,151 \\
\hline & $\mathrm{C}_{0}$ & 196 & 111 & 0,569 & 17,33 & 95,1 & 18,61 & 1,079 \\
\hline & $\mathrm{C}_{01}$ & & & & & & & \\
\hline & $\mathrm{C}_{1}$ & 196 & 113 & 0,576 & 17,20 & 109,8 & 19,33 & 1,139 \\
\hline
\end{tabular}

${ }^{\top}$ Médias obtidas depois da seleção massal para prolificidade, nos experimentos de avaliação das progênies do primeiro ciclo. Anhembi (SP) 1997.

$\mathrm{AP}=$ altura da planta $(\mathrm{cm})$;

$\mathrm{AE}=$ altura da espiga $(\mathrm{cm})$;

PRE = posição relativa da espiga na planta (AE/AP);

ST $=$ estande da parcela;

$\mathrm{PE}=$ peso de espigas (gramas / planta);

$\mathrm{NE}=$ número de espigas da parcela;

$\mathrm{NEP}=$ número de espigas / planta (NE/ST). 
Tabela 7. Médias do Ciclo $0\left(\mathrm{C}_{0}\right)$, Ciclo $1\left(\mathrm{C}_{1}\right)$ e testemunha das populações de milho submetidas ao método Seleção IG. Piracicaba (SP), 1999.

\begin{tabular}{llllllllllll}
\hline Populações & & AP & AE & PRE & ST & PE & PG & CE & DE & NE & NEP \\
\hline Piranão VF1B - P Test & 165 & 87 & 0,529 & 17,1 & 100,4 & 83,3 & 16,9 & 4,1 & 18,76 & $\mathbf{1 , 1 0 2}$ \\
& $C_{\text {o }}$ & 182 & 99 & 0,547 & 17,2 & 100,7 & 81,7 & 17,7 & 4,3 & 18,73 & $\mathbf{1 , 0 9 7}$ \\
& $C_{1}$ & 178 & 96 & 0,539 & 16,1 & 101,5 & 83,0 & 16,8 & 4,1 & 19,30 & $\mathbf{1 , 2 0 8}$ \\
\hline Piranão VF1B & Test & 173 & 92 & 0,530 & 18,4 & 143,1 & 120,0 & 17,4 & 4,3 & 20,67 & $\mathbf{1 , 1 3 0}$ \\
& $C_{\text {o }}$ & 193 & 105 & 0,539 & 15,7 & 104,3 & 85,3 & 17,9 & 4,3 & 16,83 & $\mathbf{1 , 0 8 0}$ \\
& $C_{1}$ & 196 & 108 & 0,552 & 16,9 & 125,8 & 104,5 & 17,1 & 4,1 & 20,83 & $\mathbf{1 , 2 4 0}$ \\
\hline ITA-PR & Test & 186 & 97 & 0,520 & 19,8 & 140,2 & 116,3 & 17,3 & 4,4 & 19,47 & $\mathbf{0 , 9 8 5}$ \\
& $C_{0}$ & 207 & 107 & 0,517 & 18,8 & 116,2 & 95,9 & 17,1 & 4,4 & 19,11 & $\mathbf{1 , 0 2 0}$ \\
& $C_{1}$ & 203 & 107 & 0,528 & 19,1 & 111,9 & 98,0 & 16,9 & 4,2 & 20,46 & $\mathbf{1 , 0 7 3}$ \\
\hline Pichilingue & Test & 175 & 90 & 0,513 & 19,6 & 146,8 & 123,2 & 17,2 & 4,4 & 20,22 & $\mathbf{1 , 0 3 5}$ \\
& $C_{0}$ & 166 & 79 & 0,477 & 19,5 & 99,0 & 82,5 & 15,4 & 4,2 & 18,26 & $\mathbf{0 , 9 3 9}$ \\
& $C_{1}$ & 168 & 79 & 0,471 & 15,3 & 99,5 & 84,9 & 15,3 & 4,1 & 17,82 & $\mathbf{1 , 0 0 6}$ \\
\hline Piranão VD2B & Test & 168 & 83 & 0,497 & 19,3 & 137,4 & 110,8 & 17,9 & 4,2 & 20,12 & $\mathbf{1 , 0 4 1}$ \\
& $C_{0}$ & 169 & 83 & 0,486 & 18,7 & 108,9 & 88,4 & 17,2 & 4,3 & 17,98 & $\mathbf{0 , 9 7 1}$ \\
& $C_{1}$ & 165 & 83 & 0,501 & 17,9 & 114,1 & 92,9 & 16,5 & 4,2 & 19,42 & $\mathbf{1 , 0 9 2}$ \\
\hline HXL & Test & 195 & 106 & 0,544 & 20,3 & 161,2 & 134,6 & 17,0 & 4,3 & 25,38 & $\mathbf{1 , 2 5 1}$ \\
& $C_{0}$ & 193 & 106 & 0,550 & 19,8 & 122,2 & 100,6 & 16,4 & 4,2 & 22,28 & $\mathbf{1 , 1 3 9}$ \\
& $C_{1}$ & 191 & 106 & 0,552 & 19,27 & 123,0 & 101,0 & 15,7 & 4,1 & 23,18 & $\mathbf{1 , 2 2 0}$
\end{tabular}

AP = altura da planta $(\mathrm{cm})$;

$\mathrm{AE}=$ altura da espiga $(\mathrm{cm})$;

$\mathrm{PRE}=$ posição relativa da espiga na planta (AE/AP);

ST $=$ estande da parcela;

$\mathrm{PE}=$ peso de espigas (g/planta);

$\mathrm{PG}=$ peso de grãos ( $\mathrm{g} /$ planta);

$\mathrm{CE}=$ comprimento da espiga $(\mathrm{cm})$;

$\mathrm{DE}=$ diâmetro da espiga $(\mathrm{cm})$;

$\mathrm{NE}=$ número de espigas da parcela;

$\mathrm{NEP}=$ número de espigas / planta (NE/ST). 
Tabela 8. Médias do Ciclo $0\left(\mathrm{C}_{0}\right)$, Ciclo $1\left(\mathrm{C}_{1}\right)$ e testemunha das populações de milho submetidas ao método Seleção $\mathrm{S}_{1}$. Anhembi (SP), 1999.

\begin{tabular}{|c|c|c|c|c|c|c|c|c|}
\hline População & & $\mathbf{A P}$ & $\mathbf{A E}$ & PRE & ST & $\mathbf{P E}$ & $\mathrm{NE}$ & NEP \\
\hline \multirow[t]{4}{*}{ Piranão VF1B } & Test & 205 & 120 & 0,583 & 17,8 & 144,6 & 23,25 & $1, \mathbf{3 3 0}$ \\
\hline & $\mathrm{C}_{0}$ & 222 & 137 & 0,618 & 18,3 & 111,1 & 20,83 & 1,143 \\
\hline & $\mathrm{C}_{01}^{\dagger}$ & 164 & 88 & 0,537 & 12,1 & 40,1 & 12,63 & 1,043 \\
\hline & $\mathrm{C}_{1}$ & 202 & 118 & 0,580 & 15,9 & 57,9 & 17,10 & 1,081 \\
\hline \multirow[t]{4}{*}{ ITA-PR } & Test & 197 & 116 & 0,590 & 17,67 & 128,2 & 20,93 & 1,190 \\
\hline & $\mathrm{C}_{0}$ & 210 & 123 & 0,585 & 18,33 & 103,5 & 20,15 & 1,105 \\
\hline & $\mathrm{C}_{01}^{\dagger}$ & 187 & 106 & 0,567 & 14,88 & 52,9 & 14,87 & 0,999 \\
\hline & $\mathrm{C}_{1}$ & 194 & 114 & 0,584 & 15,83 & 63,1 & 18,80 & 1,206 \\
\hline \multirow[t]{4}{*}{ Pichilingue } & Test & 188 & 108 & 0,572 & 17,97 & 124,8 & 22,50 & 1,268 \\
\hline & $\mathrm{C}_{0}$ & 188 & 100 & 0,534 & 17,27 & 86,7 & 19,47 & 1,133 \\
\hline & $\mathrm{C}_{01}^{\dagger}$ & 160 & 84 & 0,525 & 13,04 & 53,6 & 14,28 & 1,095 \\
\hline & $C_{1}$ & 172 & 91 & 1,532 & 14,45 & 53,6 & 16,18 & 1,139 \\
\hline \multirow[t]{4}{*}{ Piranão VD2B } & Test & 186 & 103 & 0,554 & 17,07 & 114,9 & 20,81 & 1,234 \\
\hline & $\mathrm{C}_{0}$ & 180 & 97 & 0,541 & 16,89 & 77,6 & 17,93 & 1,074 \\
\hline & $\mathrm{C}_{01}^{\dagger}$ & 137 & 71 & 0,518 & 12,70 & 25,9 & 10,35 & $\mathbf{0 , 8 1 5}$ \\
\hline & $\mathrm{C}_{1}$ & 162 & 89 & 0,553 & 14,83 & 38,9 & 13,90 & 0,941 \\
\hline \multirow[t]{3}{*}{ HXI } & Test & 200 & 115 & 0,572 & 18,59 & 140,7 & 23,82 & 1,289 \\
\hline & $\begin{array}{l}\mathrm{C}_{0} \\
\mathrm{C}_{01}{ }^{\dagger}\end{array}$ & 193 & 112 & 0,578 & 17,47 & 106,6 & 20,71 & 1,173 \\
\hline & $\mathrm{C}_{1}$ & 182 & 103 & 0,566 & 16,17 & 71,8 & 19,31 & 1,221 \\
\hline \multirow[t]{4}{*}{ ESALQ-PRI } & Test & 199 & 116 & 0,581 & 17,35 & 142,7 & 23,05 & 1,331 \\
\hline & $\mathrm{C}_{0}$ & 193 & 110 & 0,568 & 17,00 & 76,4 & 17,05 & 1,021 \\
\hline & $\mathrm{C}_{01}^{\dagger}$ & 170 & 92 & 0,541 & 12,99 & 52,9 & 10,52 & 0,810 \\
\hline & $\mathrm{C}_{1}$ & 188 & 109 & 0,576 & 16,08 & 55,6 & 17,59 & 1,105 \\
\hline
\end{tabular}

${ }^{\dagger}$ Médias obtidas depois da seleção massal para prolificidade, nos experimentos de avaliação das progênies do primeiro ciclo. Anhembi (SP), 1997.

$\mathrm{AP}=$ altura da planta $(\mathrm{cm})$;

$\mathrm{AE}=$ altura da espiga $(\mathrm{cm})$;

PRE = posição relativa da espiga na planta (AE/AP);

ST $=$ estande da parcela;

$\mathrm{PE}=$ peso de espigas $(\mathrm{g} / \mathrm{planta})$;

$\mathrm{NE}=$ número de espigas da parcela;

$\mathrm{NEP}=$ número de espigas / planta $(\mathrm{NE} / \mathrm{ST})$. 
Tabela 9. Médias do Ciclo $0\left(\mathrm{C}_{0}\right)$, Ciclo $1\left(\mathrm{C}_{1}\right)$ e testemunha das populações de milho submetidas ao método Seleção $S_{1}$. Anhembi (SP) em 2000.

\begin{tabular}{|c|c|c|c|c|c|c|c|c|}
\hline & & $\mathbf{A P}$ & $\mathbf{A E}$ & PRE & ST & $\mathbf{P E}$ & $\mathbf{N E}$ & NEP \\
\hline \multirow[t]{3}{*}{ Piranão VF1B } & Test, & 179 & 102 & 0,570 & 16,42 & 152,1 & 21,92 & 1,368 \\
\hline & $\mathrm{C}_{0}$ & 199 & 121 & 0,608 & 19,42 & 131,2 & 20,25 & 1,046 \\
\hline & $\mathrm{C}_{1}$ & 164 & 98 & 0,600 & 14,68 & 68,1 & 14,55 & 1,032 \\
\hline \multirow[t]{3}{*}{ Piranão VD2B } & Test, & 166 & 92 & 0,553 & 20,15 & 154,9 & 22,44 & 1,278 \\
\hline & $\mathrm{C}_{0}$ & 161 & 94 & 0,583 & 18,26 & 129,7 & 19,26 & 1,063 \\
\hline & $\mathrm{C}_{1}$ & 132 & 74 & 0,556 & 14,47 & 61,9 & 14,20 & 1,012 \\
\hline \multirow[t]{3}{*}{ Pichilingue } & Test, & 167 & 99 & 0,594 & 17,07 & 154,6 & 21,97 & 1,365 \\
\hline & $\mathrm{C}_{0}$ & 163 & 87 & 0,534 & 18,37 & 107,1 & 18,23 & 0,998 \\
\hline & $\mathrm{C}_{1}$ & 140 & 74 & 0,526 & 14,00 & 61,35 & 13,94 & 1,016 \\
\hline \multirow[t]{3}{*}{ ITA-PR } & Test, & 189 & 110 & 0,582 & 19,37 & 172,9 & 25,00 & 1,302 \\
\hline & $\mathrm{C}_{0}$ & 205 & 125 & 0,607 & 19,37 & 137,5 & 21,30 & 1,114 \\
\hline & $\mathrm{C}_{1}$ & 174 & 104 & 0,595 & 17,02 & 80,9 & 19,09 & 1,140 \\
\hline \multirow[t]{3}{*}{ HXI } & Test, & 172 & 99 & 0,575 & 19,39 & 172,9 & 26,94 & 1,414 \\
\hline & $\mathrm{C}_{0}$ & 170 & 96 & 0,563 & 18,33 & 128,4 & 21,78 & 1,190 \\
\hline & $\mathrm{C}_{1}$ & 144 & 79 & 0,547 & 14,77 & 69,5 & 16,12 & 1,107 \\
\hline \multirow[t]{3}{*}{ ESALQ-PR1 } & Test, & 190 & 116 & 0,611 & 20,41 & 206,5 & 30,27 & 1,485 \\
\hline & $\mathrm{C}_{0}$ & 186 & 111 & 0,597 & 17,05 & 93,8 & 18,10 & 1,069 \\
\hline & $C_{1}$ & 164 & 101 & 0,614 & 13,74 & 65,5 & 15,53 & 1,116 \\
\hline $\begin{array}{l}\mathrm{AP}=\text { altura da } \\
\mathrm{AE}=\text { altura da } \\
\mathrm{PRE}=\text { posição } \\
\mathrm{ST}=\text { estande da } \\
\mathrm{PE}=\text { peso de es } \\
\mathrm{NE}=\text { número } \mathrm{d} \\
\mathrm{NEP}=\text { número }\end{array}$ & $\begin{array}{l}\text { a }(\mathrm{cm}) \\
\text { a }(\mathrm{cm}) \\
\text { iva da } \\
\text { cela; } \\
\mathrm{s}(\mathrm{g} / \mathrm{pl} \\
\text { igas d } \\
\text { spigas }\end{array}$ & $\begin{array}{l}\text { a); } \\
\text { arcel }\end{array}$ & plante & $\mathrm{AE} / \mathrm{AP})$ & & & & \\
\hline
\end{tabular}


Tabela 10. Componentes de variância, média e a herdabilidade do peso de espigas (PE), peso de grãos (PG) e número de espigas por planta (NEP) em progênies de milho de primeiro ciclo dos métodos Seleção IG e Seleção $S_{1}$. Anhembi (SP), 1997.

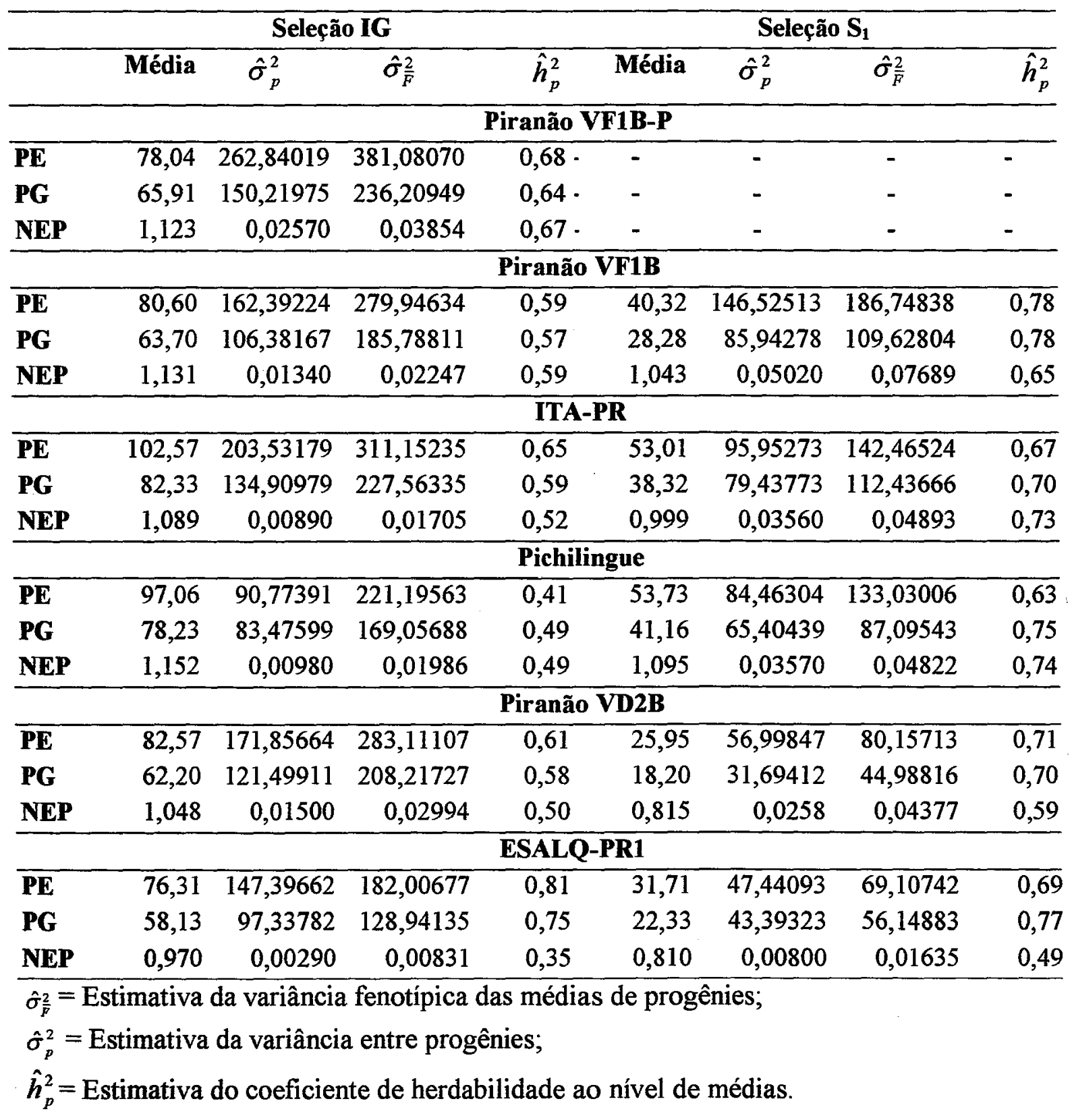


Tabela 11. Componentes de variância, média e a herdabilidade do peso de espigas ( $\mathrm{PE}$ ), peso de grãos (PG) e número de espigas por planta (NEP) em progênies de milho de segundo ciclo do método Seleção IG. Anhembi e Piracicaba (SP), 1999.

\begin{tabular}{|c|c|c|c|c|c|c|c|c|}
\hline \multicolumn{4}{|c|}{ Anhembi } & \multicolumn{5}{|c|}{ Piracicaba } \\
\hline & Média & $\hat{\sigma}_{p}^{2}$ & $\hat{\sigma}_{\bar{F}}^{2}$ & $\hat{h}_{p}^{2}$ & Média & $\hat{\sigma}_{p}^{2}$ & $\hat{\sigma}_{\bar{F}}^{2}$ & $\hat{h}_{p}^{2}$ \\
\hline & \multicolumn{8}{|c|}{ Piranão VF1B-P } \\
\hline$\overline{\mathbf{P E}}$ & 105,40 & 253,80833 & 352,55000 & 0,72 & 101,60 & 185,19167 & 360,74167 & 0,51 \\
\hline PG & & & & & 83,00 & 158,32500 & 282,70000 & 0,56 \\
\hline \multirow[t]{2}{*}{ NEP } & 1,233 & 0,01368 & 0,02608 & 0,52 & 1,208 & 0,00697 & 0,02165 & 0,32 \\
\hline & \multicolumn{8}{|c|}{ Piranão VF1B } \\
\hline$\overline{\mathbf{P E}}$ & 100,17 & 413,13216 & 495,80988 & 0,83 & 125,74 & 377,67040 & 516,96174 & 0,73 \\
\hline PG & & & & & 104,55 & 296,31667 & 394,22500 & 0,75 \\
\hline \multirow[t]{2}{*}{ NEP } & 1,208 & 0,00694 & 0,02385 & 0,29 & 1,242 & 0,00442 & 0,02153 & 0,21 \\
\hline & \multicolumn{8}{|c|}{ ITA-PR } \\
\hline$\overline{\mathbf{P E}}$ & 105,55 & 214,27500 & 319,20000 & 0,67 & 111,95 & 245,32333 & 437,90000 & 0,79 \\
\hline PG & & & & & 93,00 & 252,75830 & 321,24667 & 0,79 \\
\hline \multirow[t]{2}{*}{ NEP } & 1,165 & 0,00484 & 0,01894 & 0,26 & 1,074 & 0,00876 & 0,01426 & 0,61 \\
\hline & \multicolumn{8}{|c|}{ Pichilingue } \\
\hline$\overline{\mathbf{P E}}$ & 104,95 & 76,20000 & 144,41667 & 0,55 & 99,80 & 146,64167 & 284,03333 & 0,52 \\
\hline PG & & & & & 84,85 & 121,16667 & 226,67500 & 0,53 \\
\hline \multirow[t]{2}{*}{ NEP } & 1,194 & 0,01161 & 0,02576 & 0,45 & 1,006 & 0,00221 & 0,01085 & 0,20 \\
\hline & \multicolumn{8}{|c|}{ Piranão VD2B } \\
\hline$\overline{\mathbf{P E}}$ & 96,45 & 224,18333 & 308,98333 & 0,73 & 114,05 & 338,84475 & 484,84289 & 0,70 \\
\hline PG & & & & & 92,05 & 251,06502 & 352,43746 & 0,71 \\
\hline NEP & 1,108 & 0,00881 & 0,01883 & 0,47 & 1,092 & 0,01578 & 0,02500 & 0,63 \\
\hline & \multicolumn{8}{|c|}{ HXL } \\
\hline$\overline{\mathbf{P E}}$ & 109,77 & 131,13389 & 195,79040 & 0,67 & 123,13 & 293,00001 & 417,59685 & 0,70 \\
\hline PG & & & & & 101,21 & 222,03943 & 311,33327 & 0,71 \\
\hline NEP & 1,139 & 0,01008 & 0,01626 & 0,62 & 1,219 & 0,01430 & 0,02618 & 0,55 \\
\hline
\end{tabular}

$\hat{\sigma}_{\bar{F}}^{2}=$ Estimativa da variância fenotípica das médias de progênies;

$\hat{\sigma}_{p}^{2}=$ Estimativa da variância entre progênies;

$\hat{h}_{p}^{2}=$ Estimativa do coeficiente de herdabilidade ao nível de médias. 
Tabela 12. Componentes de variância, média e a herdabilidade do peso de espigas (PE), peso de grãos (PG) e número de espigas por planta (NEP) em progênies de milho de segundo ciclo do método Seleção $S_{1}$. Anhembi (SP), 1999 e 2000.

\begin{tabular}{|c|c|c|c|c|c|c|c|c|}
\hline & Média & $\hat{\sigma}_{p}^{2}$ & $\hat{\sigma}_{\bar{F}}^{2}$ & $\hat{h}_{p}^{2}$ & Média & $\hat{\sigma}_{p}^{2}$ & $\hat{\sigma}_{\bar{F}}^{2}$ & $\hat{h}_{p}^{2}$ \\
\hline & \multicolumn{4}{|c|}{ Anhembi (1999) } & \multicolumn{4}{|c|}{ Anhembi (2000) } \\
\hline & \multicolumn{8}{|c|}{ Piranão VF1B } \\
\hline$\overline{\mathbf{P E}}$ & 56,35 & 106,21667 & 143,58333 & 0,74 & 68,22 & 51,98650 & 143,09578 & 0,36 \\
\hline \multirow[t]{2}{*}{ NEP } & 1,081 & 0,02676 & 0,03900 & 0,69 & 1,033 & 0,01103 & 0,03336 & 0,33 \\
\hline & \multicolumn{8}{|c|}{ ITA-PR } \\
\hline$\overline{\mathbf{P E}}$ & 63,03 & 133,17238 & 163,19731 & 0,82 & 80,84 & 194,25614 & 276,58371 & 0,70 \\
\hline \multirow[t]{2}{*}{ NEP } & 1,206 & 0,02771 & 0,04047 & 0,68 & 1,141 & 0,02051 & 0,03753 & 0,55 \\
\hline & \multicolumn{8}{|c|}{ Pichilingue } \\
\hline PE & 53,56 & 88,86114 & 116,05833 & 0,76 & 61,30 & 200,16667 & 263,74167 & 0,76 \\
\hline \multirow[t]{2}{*}{ NEP } & 1,139 & 0,01325 & 0,03138 & 0,42 & 1,016 & 0,00960 & 0,03446 & 0,28 \\
\hline & \multicolumn{8}{|c|}{ Piranão VD2B } \\
\hline$\overline{\mathbf{P E}}$ & 38,90 & 62,18519 & 87,25837 & $\overline{0,71}$ & 62,14 & 195,12732 & 263,81861 & 0,74 \\
\hline \multirow[t]{2}{*}{ NEP } & 0,941 & 0,0191 & 0,03263 & 0,59 & 1,012 & 0,02827 & 0,05001 & 0,57 \\
\hline & \multicolumn{8}{|c|}{ HXL } \\
\hline $\mathbf{P E}$ & 71,81 & 104,08626 & 131,62156 & 0,79 & 70,40 & 177,72234 & 264,25740 & 0,67 \\
\hline \multirow[t]{2}{*}{ NEP } & 1,221 & 0,02167 & 0,03499 & 0,62 & 1,118 & 0,03526 & 0,05600 & 0,63 \\
\hline & \multicolumn{8}{|c|}{ ESALQ-PR1 } \\
\hline$\overline{\mathbf{P E}}$ & 58,58 & 354,80292 & 389,83933 & 0,91 & 66,00 & 354,09083 & 419,68083 & 0,84 \\
\hline NEP & 1,105 & 0,05105 & 0,06760 & 0,76 & 1,121 & 0,04032 & 0,05935 & 0,68 \\
\hline
\end{tabular}


Tabela 13. Ganho genético esperado e realizado em porcentagem nos dois ciclos seletivos das populações de milho submetidas aos métodos Seleção IG e Seleção $S_{1}$ (entre parênteses). Piracicaba e Anhembi (SP), 1997 e 1999.

\begin{tabular}{|c|c|c|c|c|c|}
\hline \multirow{3}{*}{ Populações } & \multicolumn{3}{|c|}{ Ciclo 1} & \multirow{2}{*}{\multicolumn{2}{|c|}{$\frac{\text { Ciclo 2 }}{\text { Esperado }}$}} \\
\hline & \multirow[t]{2}{*}{ Esperado } & \multicolumn{2}{|c|}{ Realizado } & & \\
\hline & & Anhembi & Piracicaba & Anhembi & Piracicaba \\
\hline \multirow[t]{2}{*}{ Piranão VF1B-P } & 15,09 & 16,76 & 10,13 & 12,35 & 6,91 \\
\hline & -- & $-\cdots$ & ---- & --- & --- \\
\hline \multirow[t]{2}{*}{ Piranão VF1B } & 10,72 & 10,02 & 14,78 & 1,76 & 3,83 \\
\hline & $(14,74)$ & $(-5,42)$ & $(-1,27)^{\dagger}$ & $(14,61)$ & $(6,78)^{\dagger}$ \\
\hline \multirow[t]{2}{*}{ ITA-PR } & 6,54 & 9,75 & 5,16 & 5,35 & 11,15 \\
\hline & $(16,74)$ & $(9,18)$ & $(2,29)^{\dagger}$ & $(12,24)$ & $(10,00)$ \\
\hline \multirow[t]{2}{*}{ Pichilingue } & 7,55 & 16,23 & 7,14 & 9,74 & 2,85 \\
\hline & $(16,58)$ & $(0,57)$ & $(1,77)^{\dagger}$ & $(7,57)$ & $(5,90)^{\dagger}$ \\
\hline \multirow[t]{2}{*}{ Piranão VD2B } & 7,16 & 11,81 & 12,42 & 9,98 & 15,51 \\
\hline & $(13,13)$ & $(-12,38)$ & $(-4,99)^{\dagger}$ & $(11,77)$ & $(12,98)^{\dagger}$ \\
\hline \multirow[t]{2}{*}{$\overline{\mathrm{HXL}}$} & --- & 5,57 & 7,09 & 11,29 & 12,62 \\
\hline & -- & $(4,10)$ & $(-7,50)^{\dagger}$ & $(8,54)$ & $(12,00)^{\dagger}$ \\
\hline \multirow[t]{2}{*}{ ESALQ-PR1 } & -- & --- & -- & -- & -- \\
\hline & -- & $(8,26)$ & $(4,29)^{\dagger}$ & $(15,38)$ & $(12,70)^{\dagger}$ \\
\hline \multirow[t]{2}{*}{ Médias } & 9,41 & \multicolumn{2}{|c|}{10,58} & \multicolumn{2}{|c|}{8,61} \\
\hline & $(15,30)$ & \multicolumn{2}{|c|}{$(-1,37))$} & \multicolumn{2}{|c|}{$(10,86)$} \\
\hline
\end{tabular}

Anhembi (SP), 2000. 
Tabela 14. Estimativa da correlação genética $\left(\hat{r}_{g}\right)$ e correlação fenotípica $\left(\hat{r}_{f}\right)$ entre o número de espigas por planta (NEP) e a produção de espigas (PE) nas populações de milho submetidas aos métodos Seleção IG e Seleção $S_{1}$ (entre parênteses). Anhembi e Piracicaba (SP), 1999.

\begin{tabular}{lcccc}
\hline \multirow{2}{*}{ Populações } & \multicolumn{2}{c}{ Anhembi } & \multicolumn{2}{c}{ Piracicaba } \\
\cline { 2 - 5 } & $\hat{r}_{g}$ & $\hat{r}_{f}$ & $\hat{r}_{g}$ & $\hat{r}_{f}$ \\
\hline Piranão VF1B-P & 0,39 & 0,41 & 0,32 & 0,48 \\
& --- & $-\cdots$ & $\cdots$ & -- \\
\hline Piranão VF1B & 0,92 & 0,40 & 0,34 & 0,46 \\
& $(0,50)$ & $(0,55)$ & $(0,25)^{\dagger}$ & $(0,26)^{\dagger}$ \\
\hline ITA-PR & 0,20 & 0,24 & 0,52 & 0,52 \\
& $(0,61)$ & $(0,56)$ & $(0,62)^{\dagger}$ & $(0,61)^{\dagger}$ \\
\hline Pichilingue & 0,50 & 0,21 & 0,79 & 0,64 \\
& $(0,23)$ & $(0,28)$ & $(0,52)^{\dagger}$ & $(0,53)^{\dagger}$ \\
\hline Piranão VD2B & 0,38 & 0,42 & 0,37 & 0,46 \\
& $(0,45)$ & $(0,46)$ & $(0,65)^{\dagger}$ & $(0,59)^{\dagger}$ \\
\hline HXL & 0,39 & 0,38 & 0,18 & 0,37 \\
& $(0,47)$ & $(0,48)$ & $(0,49)^{\dagger}$ & $(0,54)^{\dagger}$ \\
\hline ESALQ-PR1 & --- & -- & -- & -- \\
& $(0,86)$ & $(0,79)$ & $(0,82)^{\dagger}$ & $(0,74)^{\dagger}$ \\
\hline Média & $\mathbf{0 , 4 6}$ & $\mathbf{0 , 3 4}$ & $\mathbf{0 , 4 2}$ & $\mathbf{0 , 4 9}$ \\
& $\mathbf{( 0 , 5 2 )}$ & $\mathbf{( 0 , 5 2 )}$ & $(\mathbf{0 , 5 6})^{\dagger}$ & $(\mathbf{0 , 5 5})^{\dagger}$ \\
\hline
\end{tabular}

Anhembi (SP), 2000. 
Tabela 15. Resposta correlacionada estimada e realizada em porcentagem da seleção para a prolificidade sobre a produção de espigas $\left(R_{P E, N E P}\right)$, nas populações de milho submetidas aos métodos Seleção IG e Seleção $S_{1}$ (valores entre parênteses). Anhembi e Piracicaba (SP), 1997 e 1999.

\begin{tabular}{|c|c|c|c|c|c|}
\hline \multirow{3}{*}{ Populações } & \multicolumn{3}{|c|}{ Ciclo 1} & \multirow{2}{*}{\multicolumn{2}{|c|}{$\begin{array}{c}\text { Ciclo 2 } \\
\text { Esperado }\end{array}$}} \\
\hline & \multirow[t]{2}{*}{ Esperado } & \multicolumn{2}{|c|}{ Realizado } & & \\
\hline & & Anhembi & Piracicaba & Anhembi & Piracicaba \\
\hline \multirow[t]{2}{*}{ Piranão VF1B-P } & 9,38 & 3,84 & 0,82 & 6,18 & 3,92 \\
\hline & --- & & & -- & -- \\
\hline \multirow[t]{2}{*}{ Piranão VF1B } & 9,61 & 20,86 & 20,61 & 7,16 & 6,82 \\
\hline & $(11,60)$ & & & $(8,60)$ & $(5,50)^{\dagger}$ \\
\hline \multirow[t]{2}{*}{ ITA-PR } & 0 & $-0,76$ & $-3,64$ & 2,11 & 10,26 \\
\hline & $(8,27)$ & & & $(9,92)$ & $(8,58)^{\dagger}$ \\
\hline \multirow[t]{2}{*}{ Pichilingue } & 0 & 2,15 & 0,53 & 0,20 & 5,80 \\
\hline & $(19,68)$ & & & $(3,00)$ & $(6,24)^{\dagger}$ \\
\hline \multirow[t]{2}{*}{ Piranão VD2B } & 5,28 & 9,97 & 4,74 & 6,29 & 7,44 \\
\hline & $(0)$ & & & $(7,26)$ & $(11,64)^{\dagger}$ \\
\hline \multirow[t]{2}{*}{$\overline{\mathrm{HXI}}$} & --- & 15,42 & 0,68 & 4,62 & 2,59 \\
\hline & --- & & & $(5,59)$ & $(6,58)^{\dagger}$ \\
\hline \multirow[t]{2}{*}{ ESALQ-PR1 } & $-\cdots$ & --- & --- & -- & -- \\
\hline & -- & -- & -- & $(21,77)$ & $(16,66)^{\dagger}$ \\
\hline \multirow[t]{2}{*}{ Médias } & 4,85 & \multicolumn{2}{|c|}{6,27} & \multicolumn{2}{|r|}{5,28} \\
\hline & $(9,89)$ & \multicolumn{2}{|c|}{-} & \multicolumn{2}{|r|}{$(9,62)$} \\
\hline
\end{tabular}

Anhembi (SP), em 2000. 
宽

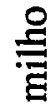

$\ddot{8}$

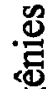

\&্口

늘

宽

若

\&

$\frac{8}{8}$

$\frac{8}{8}$

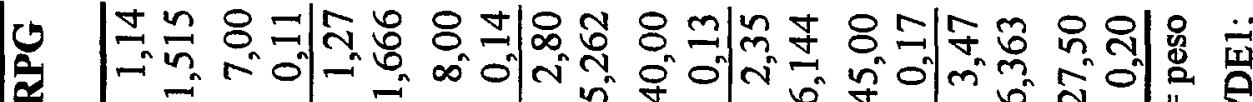
-

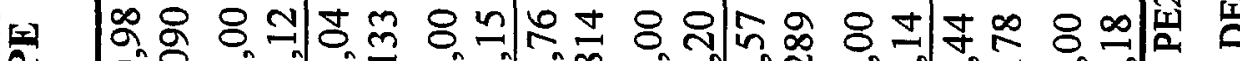

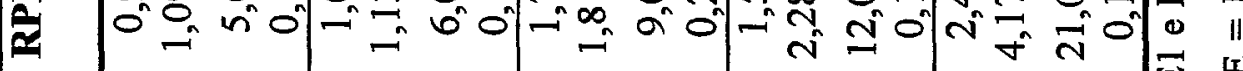

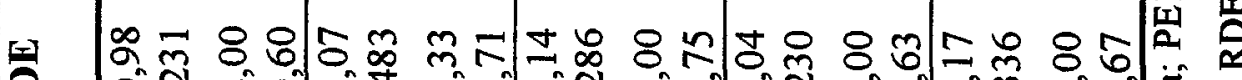

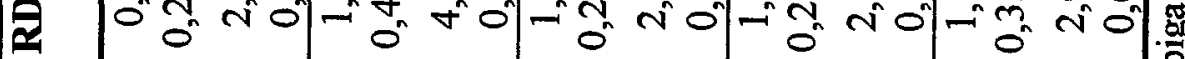

$m$ m $N$ N ง m. 김

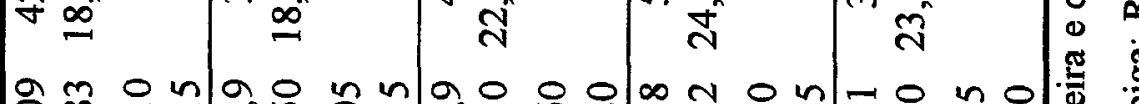
热

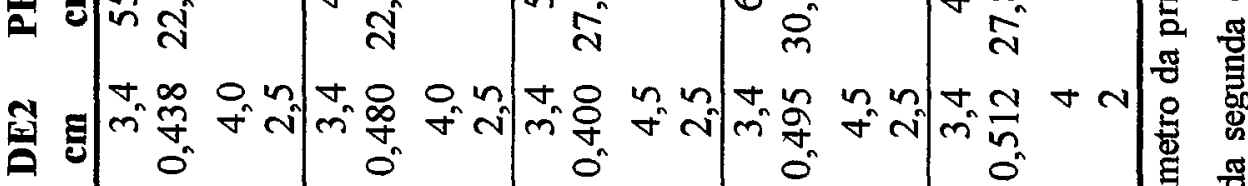

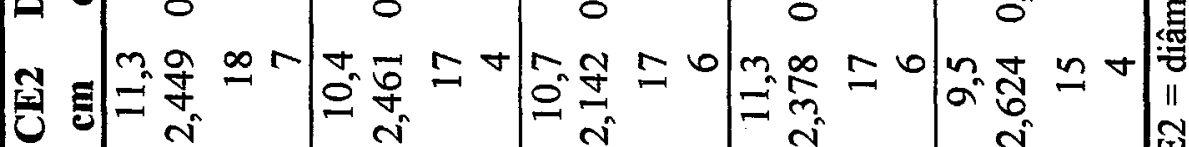

(is

究

울

के y

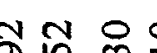

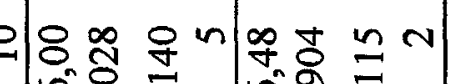
N 䒔 然

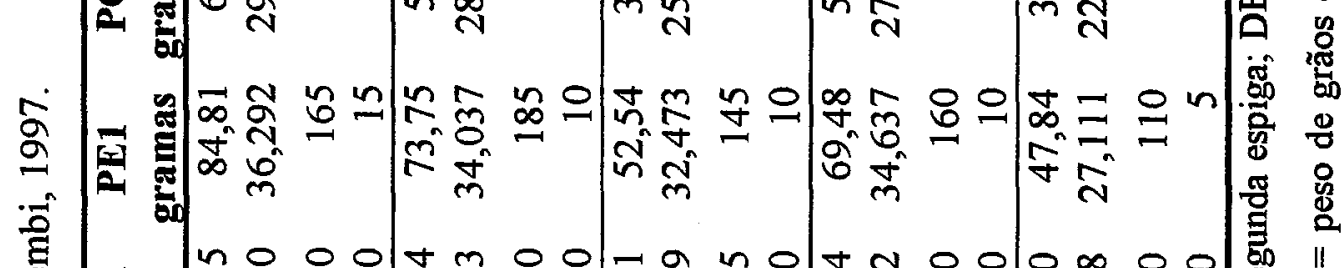

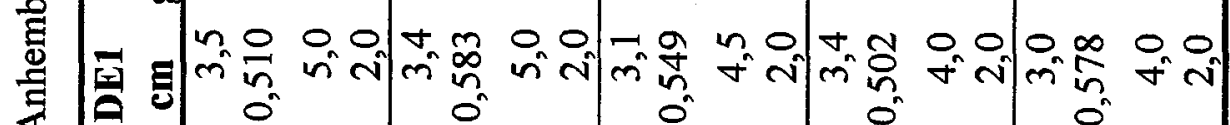

要

窟

:

콩ำ

$$
\begin{aligned}
& \text { in } \\
& 8 \\
& \text { तN }
\end{aligned}
$$

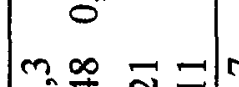

$$
0
$$

$$
\text { in }
$$

틀

| 
$\frac{0}{0}$

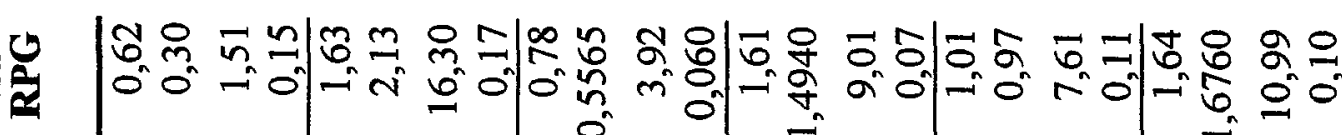

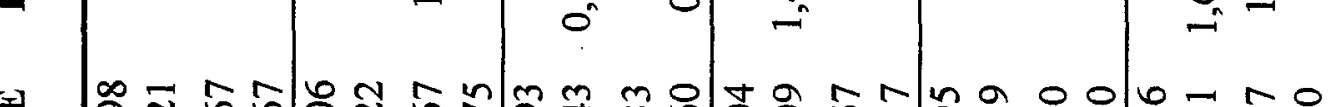

용

201ㄴ.

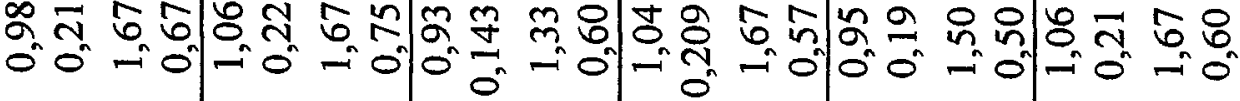

.

四

ఇ

운

$\simeq$

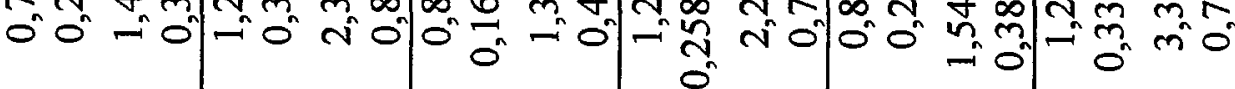

๘

ซ్ర

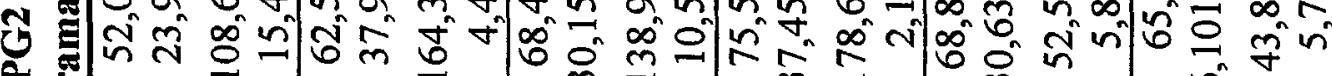

.

8

$\stackrel{8}{0}$

ర

\&

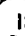

융

.

党

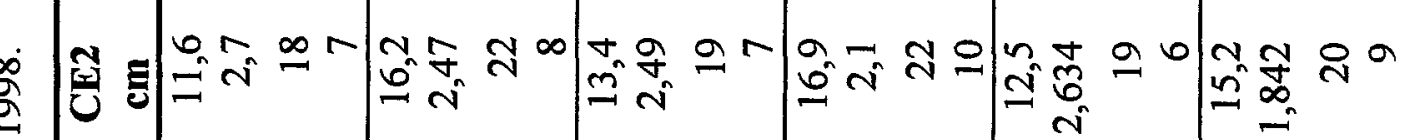

ஊn்

T) 팸ㅇ

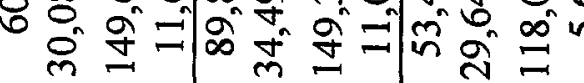

I

$\frac{0}{0}$

:

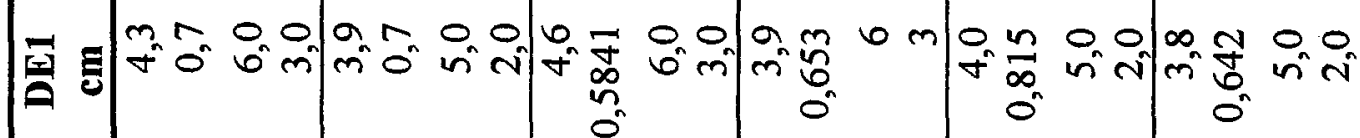

की

.

की

光

过

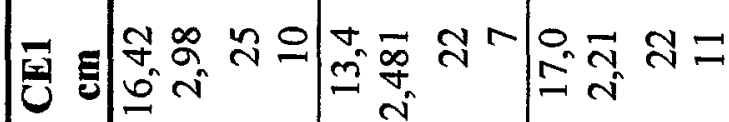

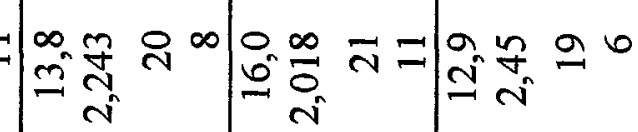

0

(n)

$\frac{0}{\pi} \stackrel{\frac{0}{\pi}}{\circ}$

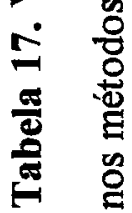

总

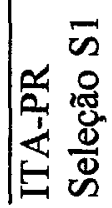

|용

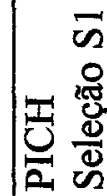

兽 


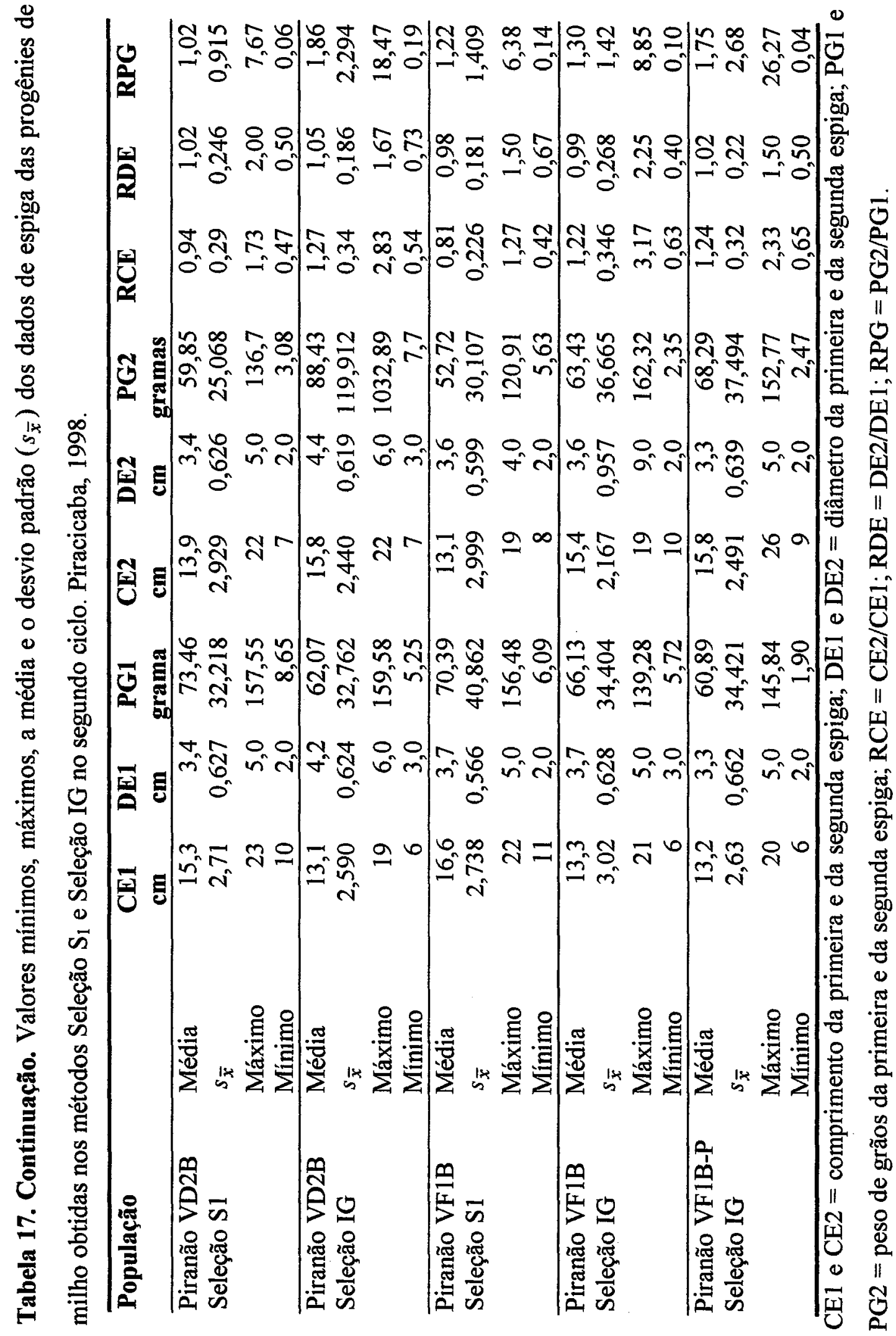




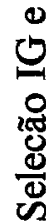

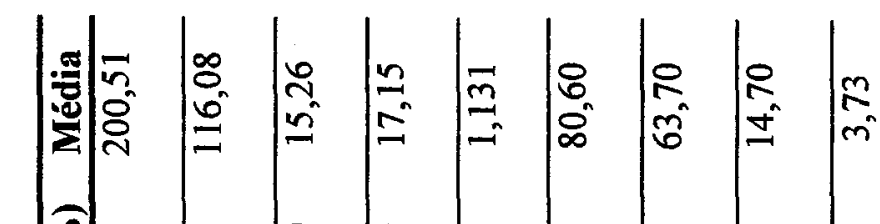

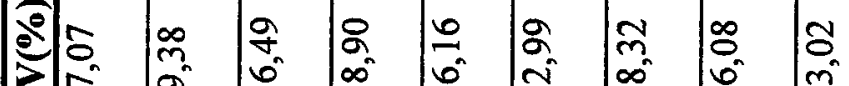

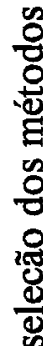

$\stackrel{0}{\square}$

$\frac{0}{\circ}$

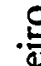

䛼

象

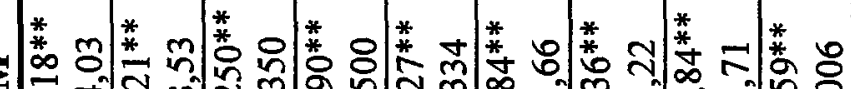

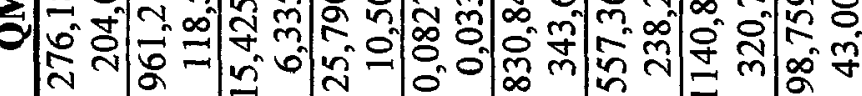

富

胥

容言

of

品

高够高

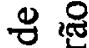

要要

政

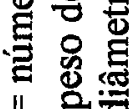

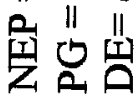

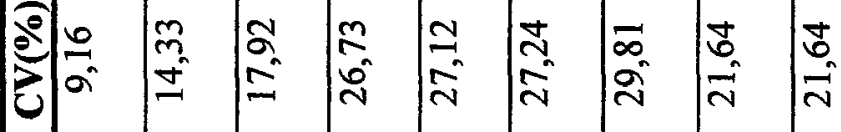

宛

है

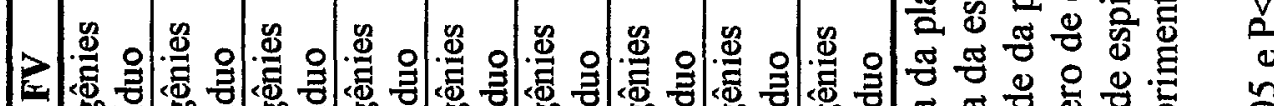

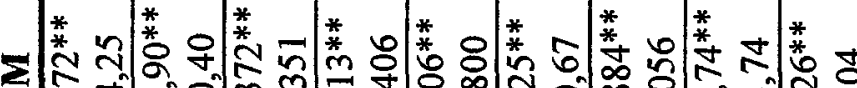

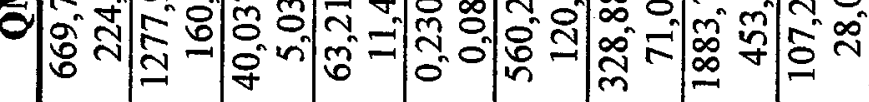

开证

एक्ष

$\hat{\Omega}$

귑)

兽

$\dot{\theta} \dot{\vec{s}}$

蛋

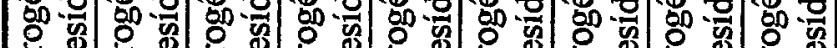

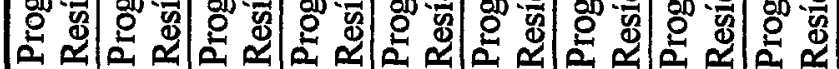

중 至焉寻品

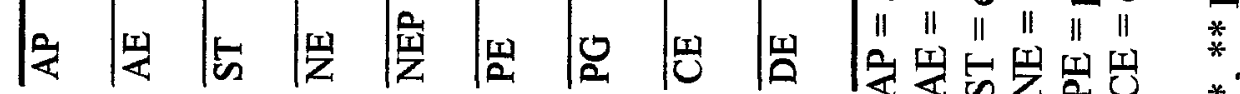




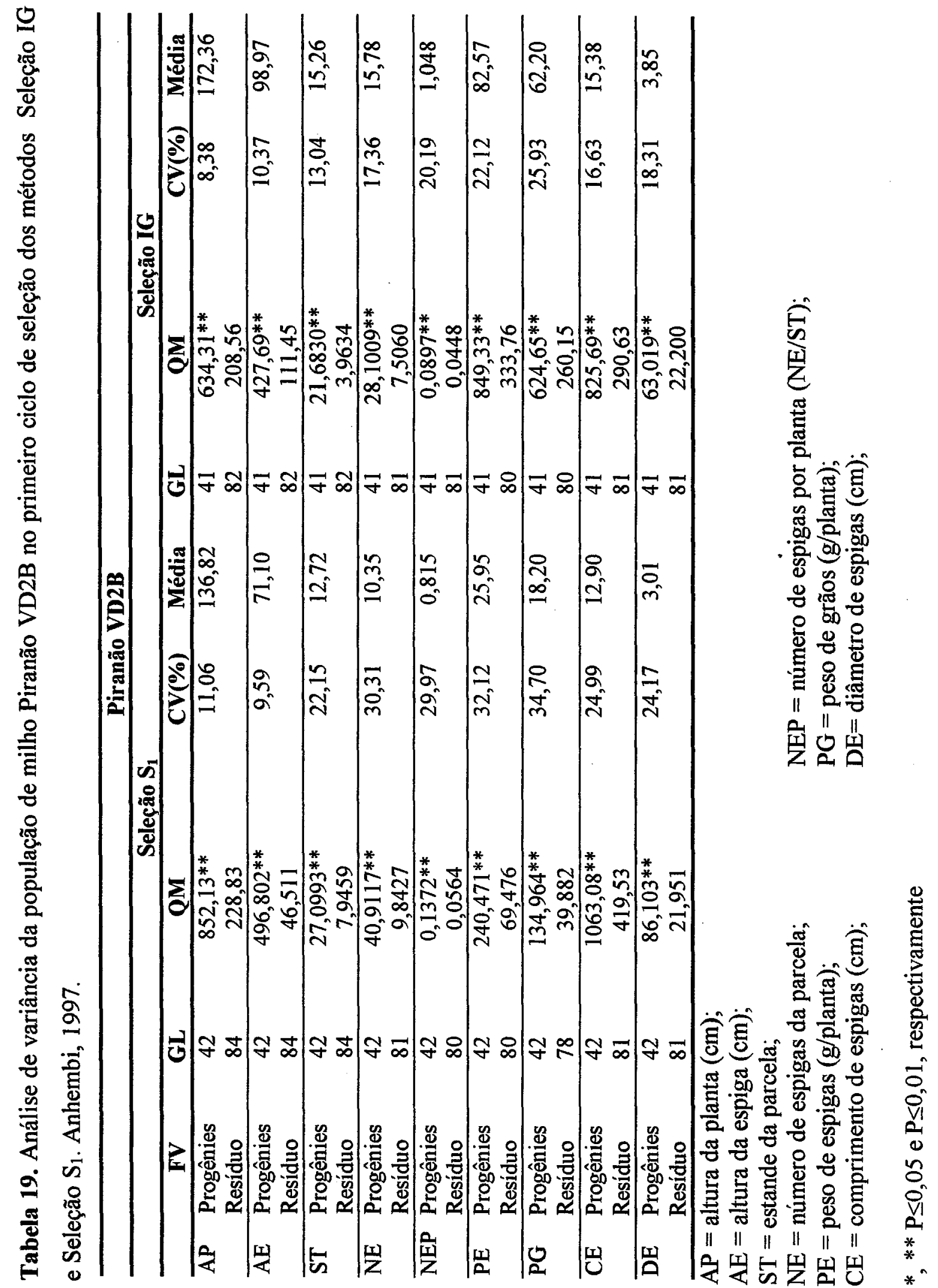




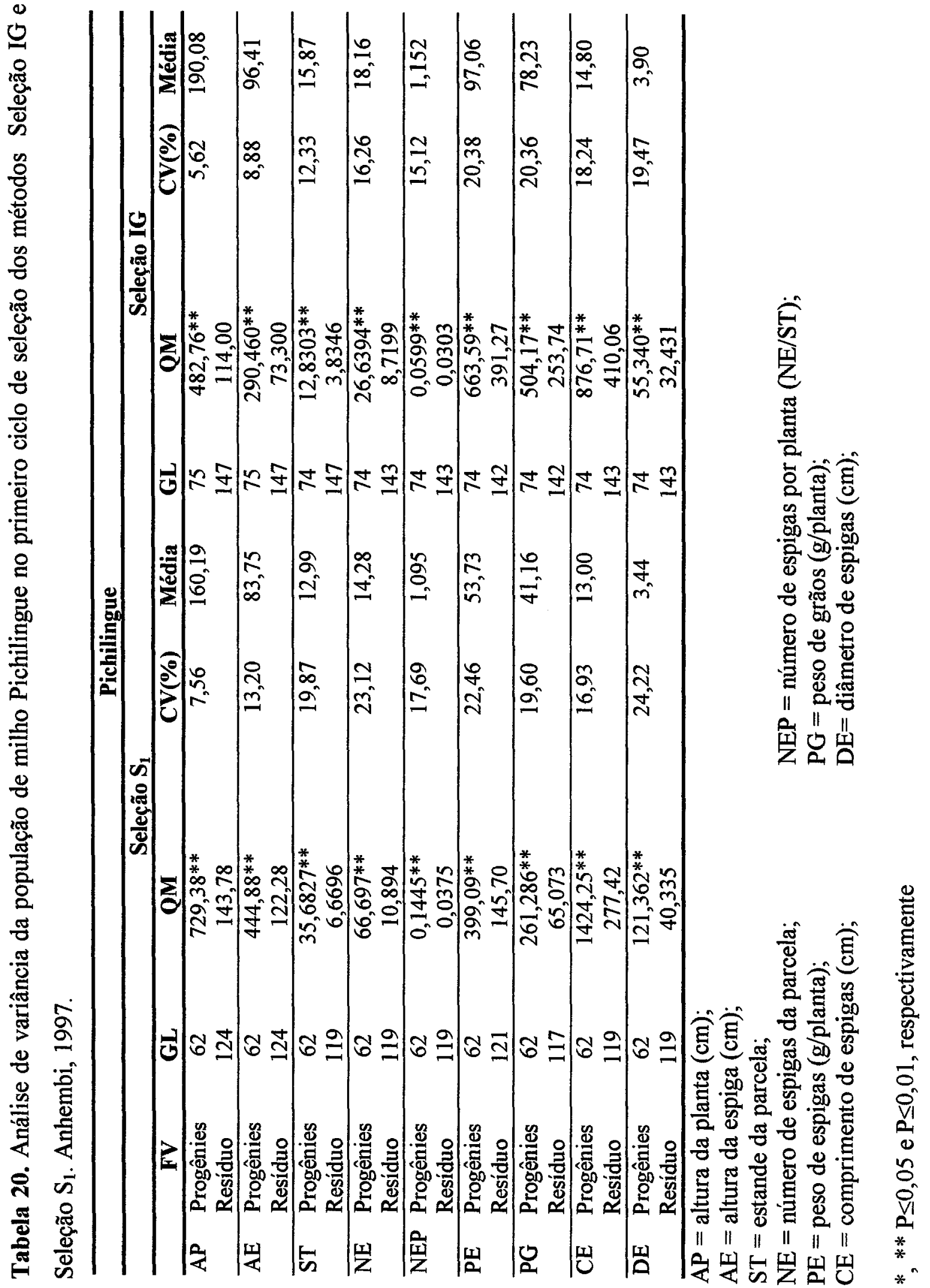


过

8
$\frac{8}{8}$
8
8
8
8

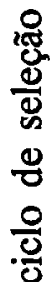

童

势

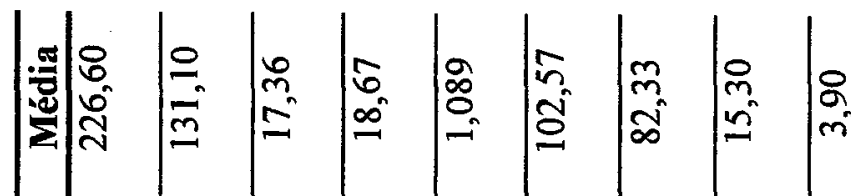

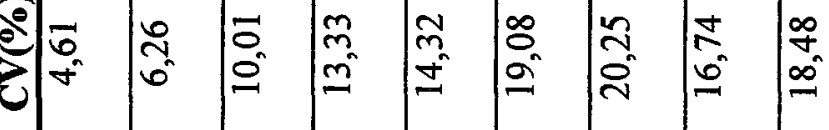

옳

ष

\&

흥

항응

충

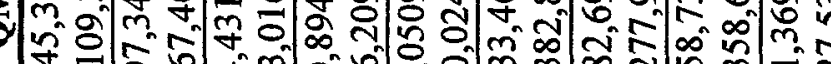

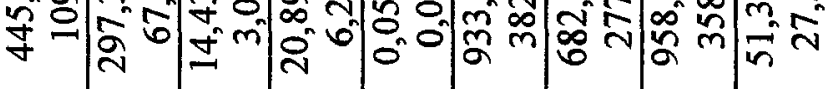

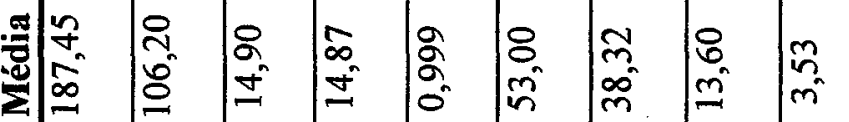

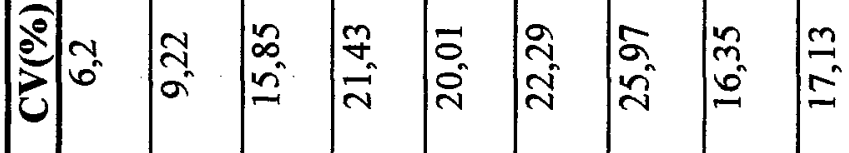

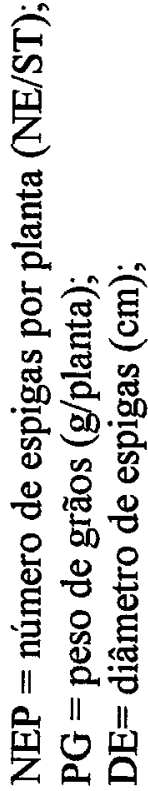

.

殸

s.

ज़:

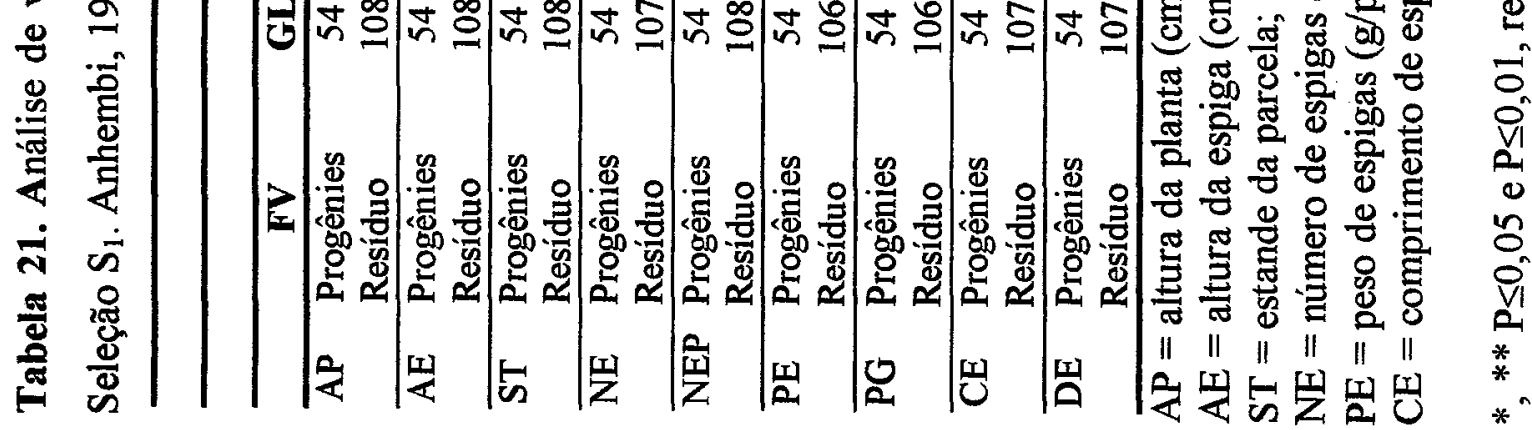

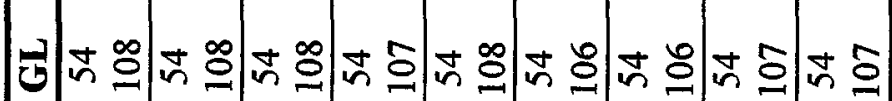

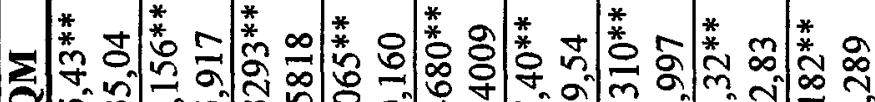

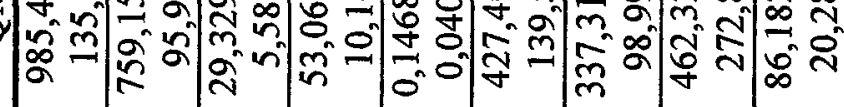

छึ.

䒿

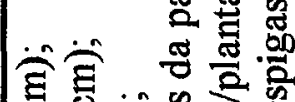

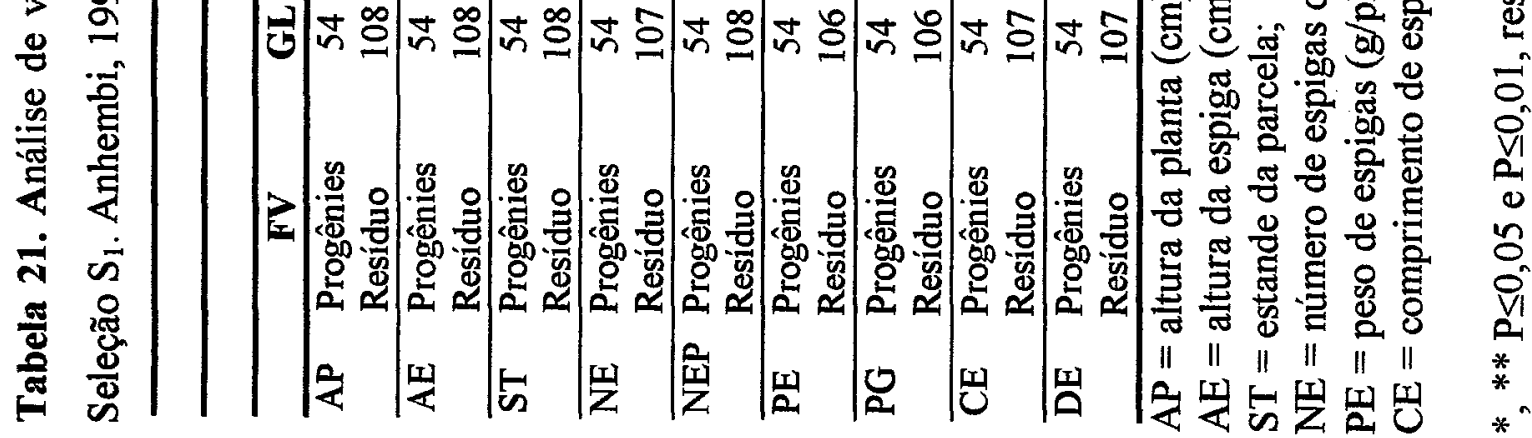




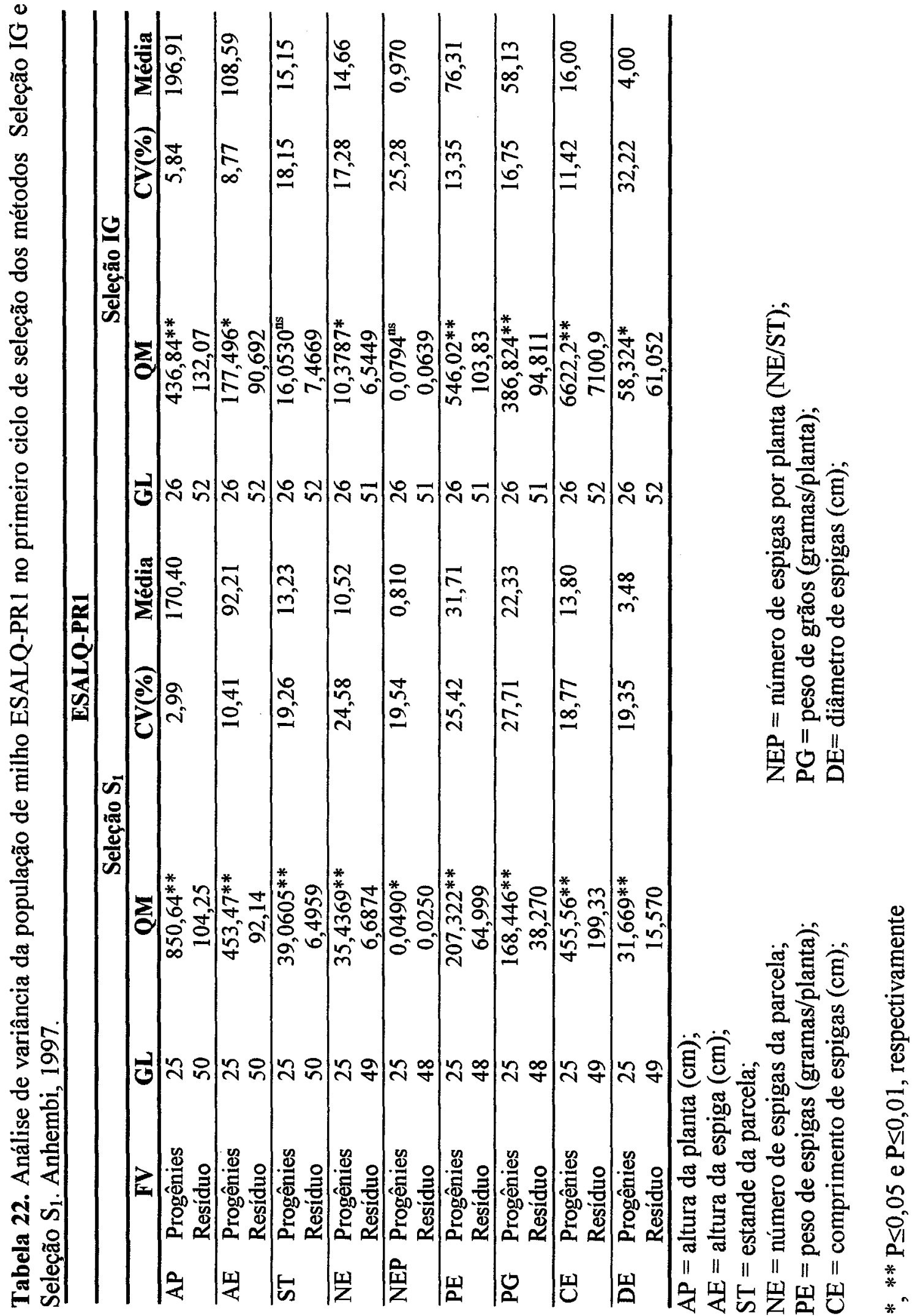




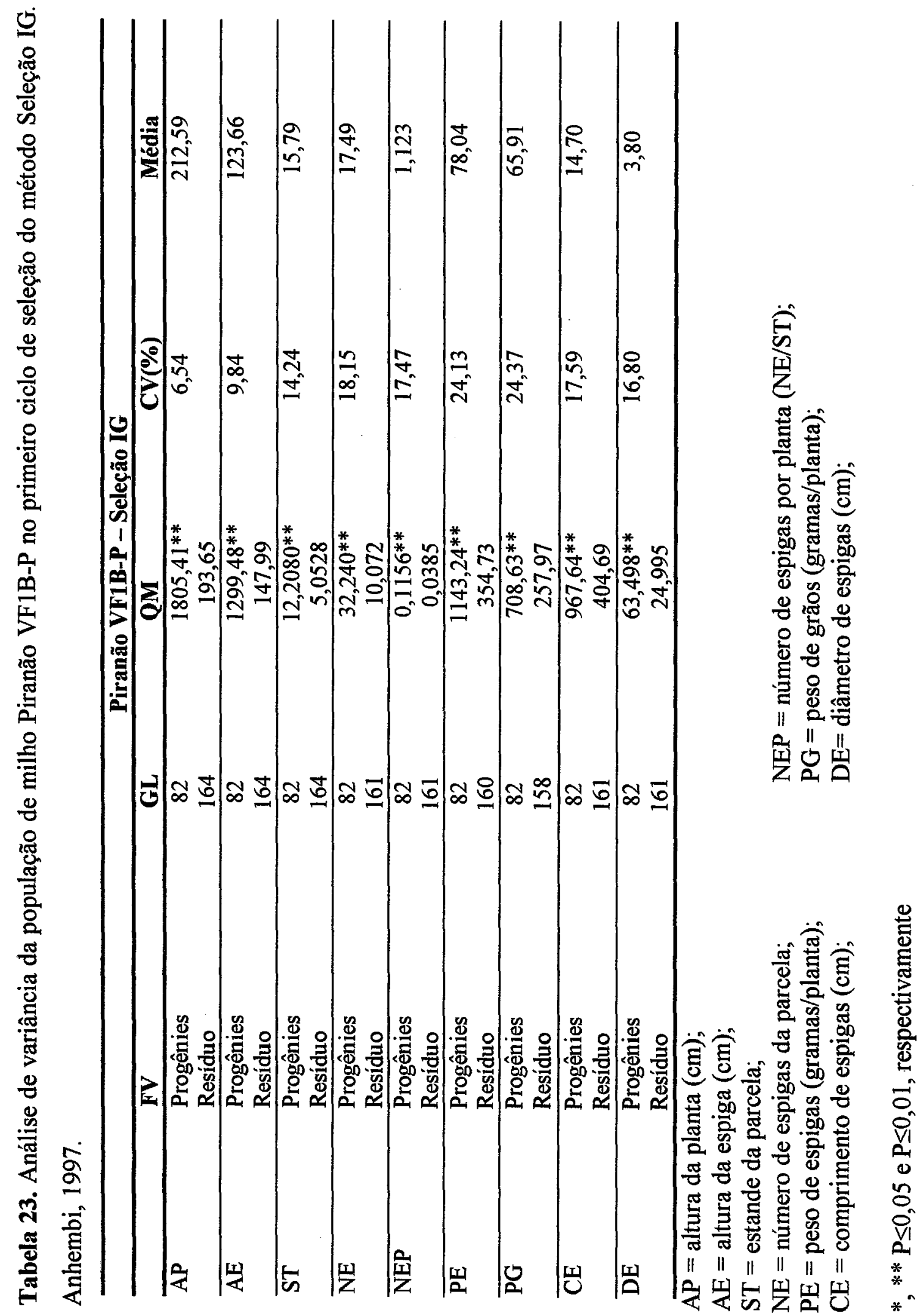




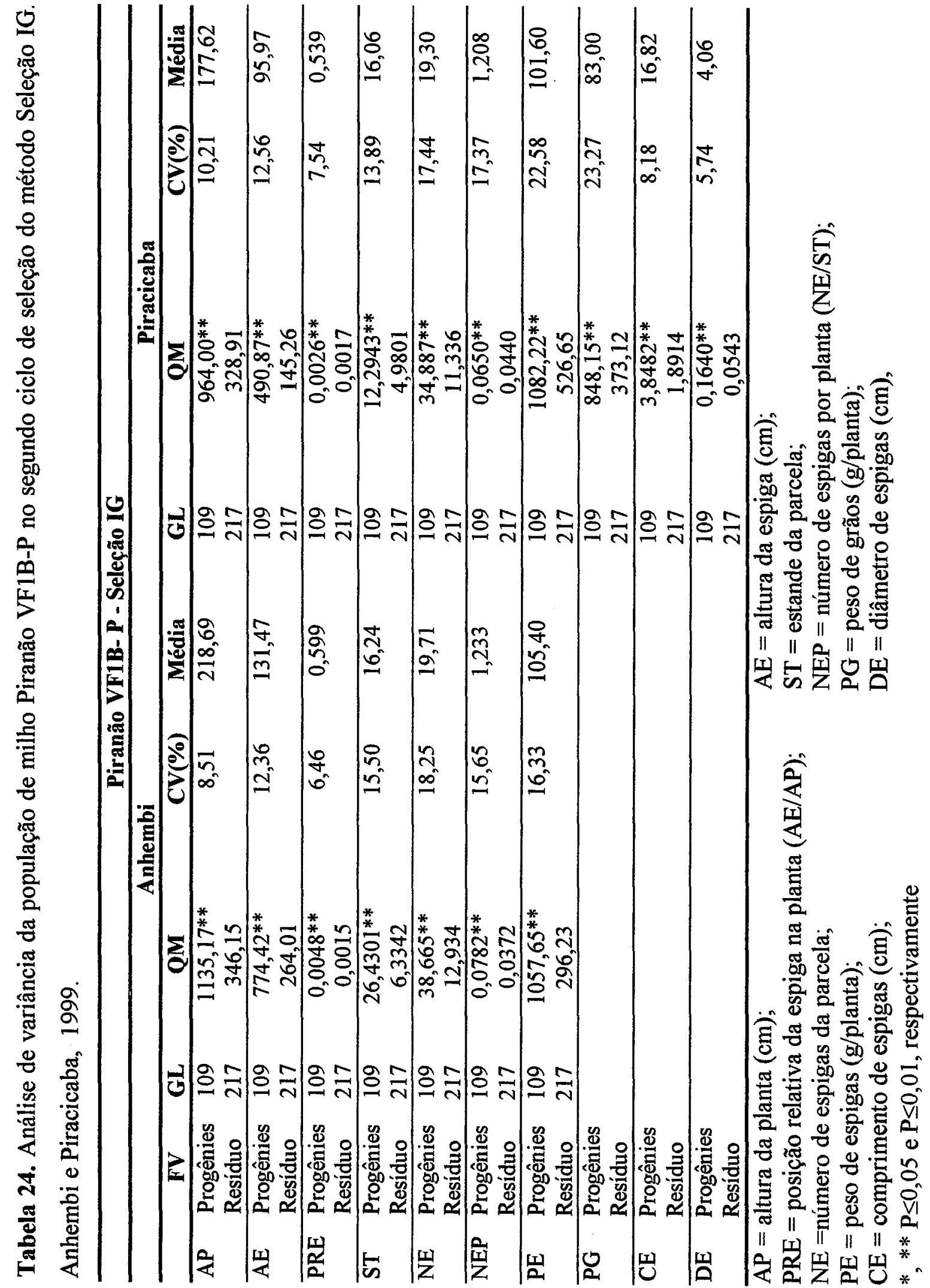




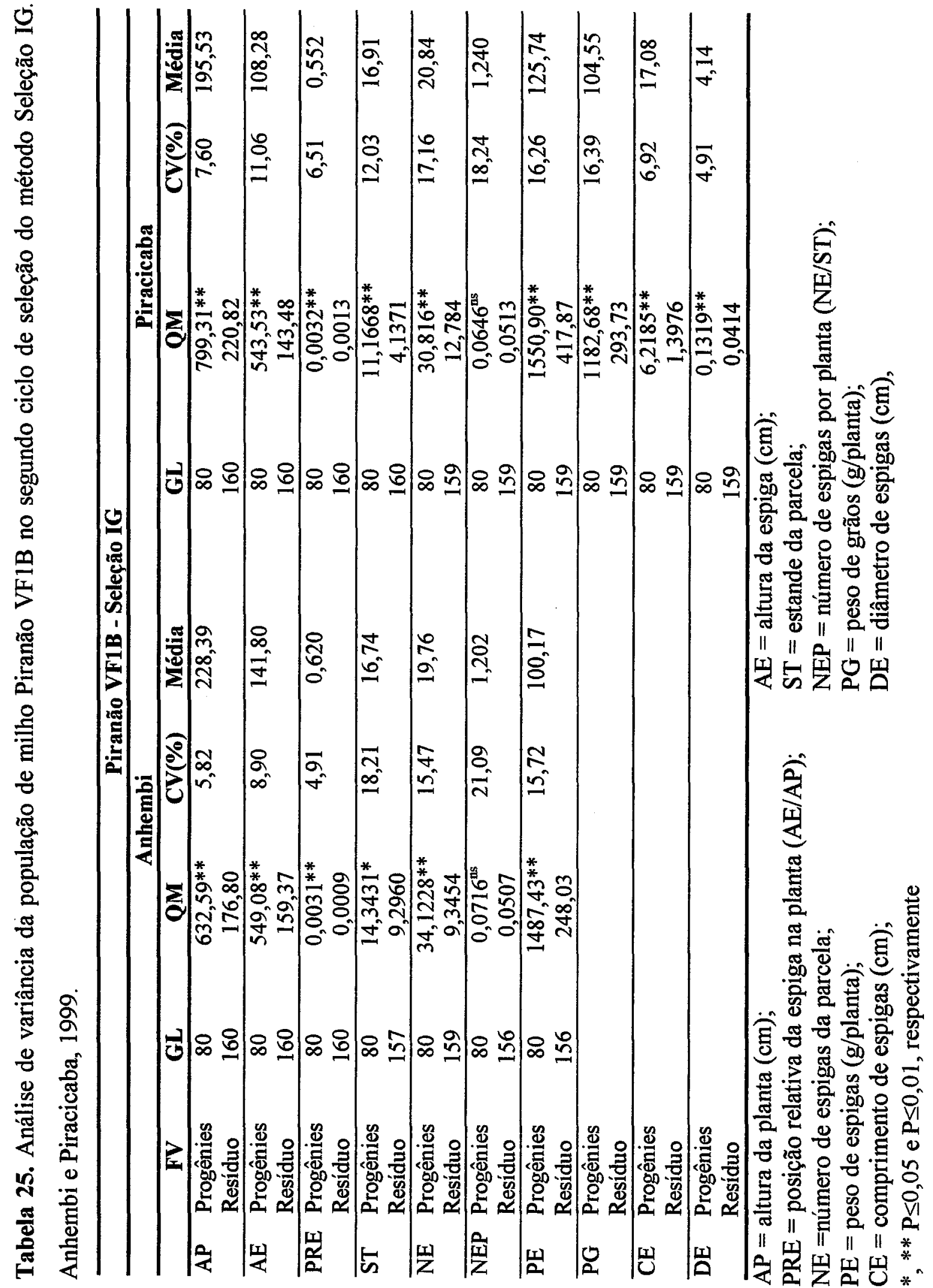




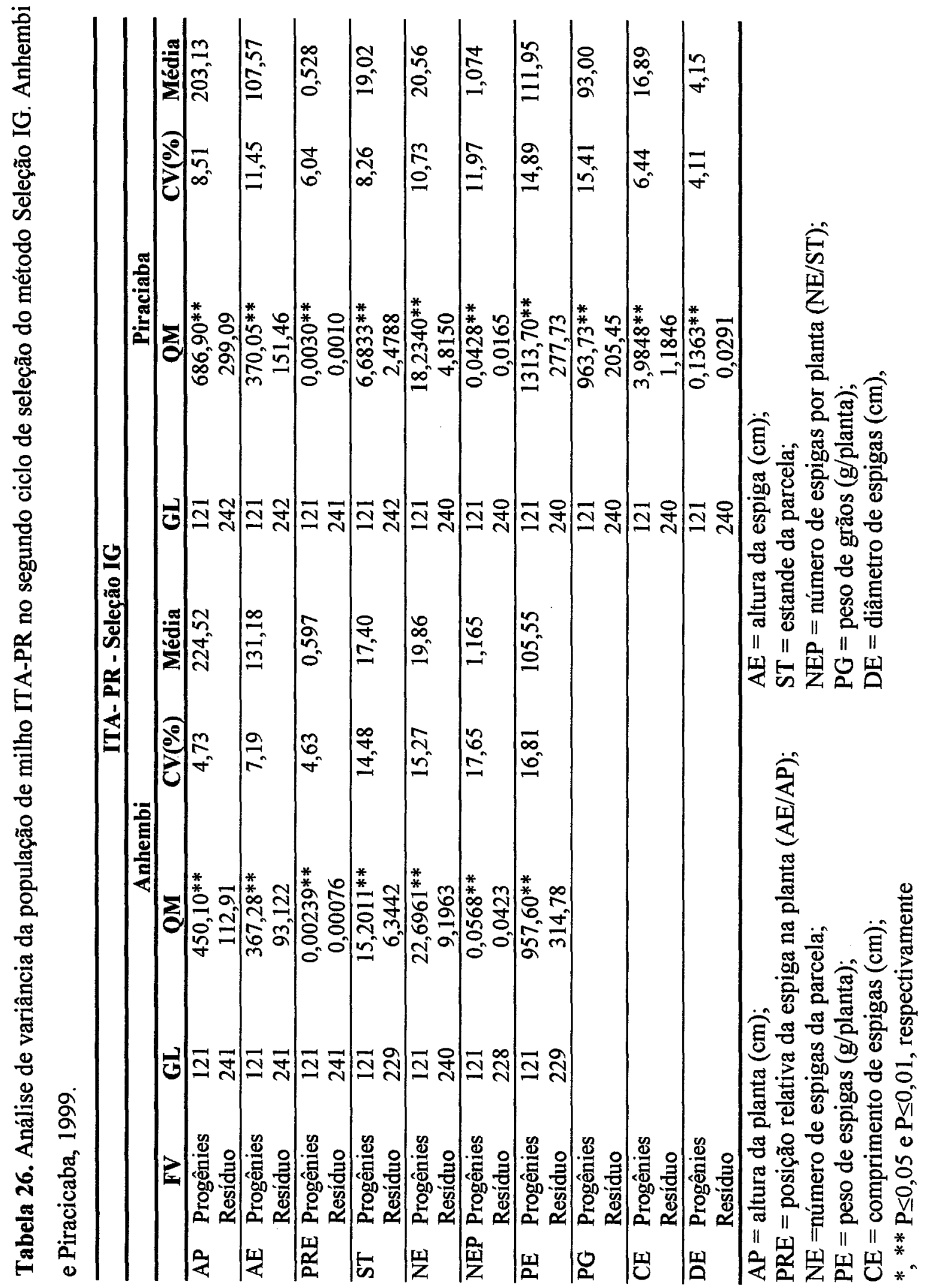




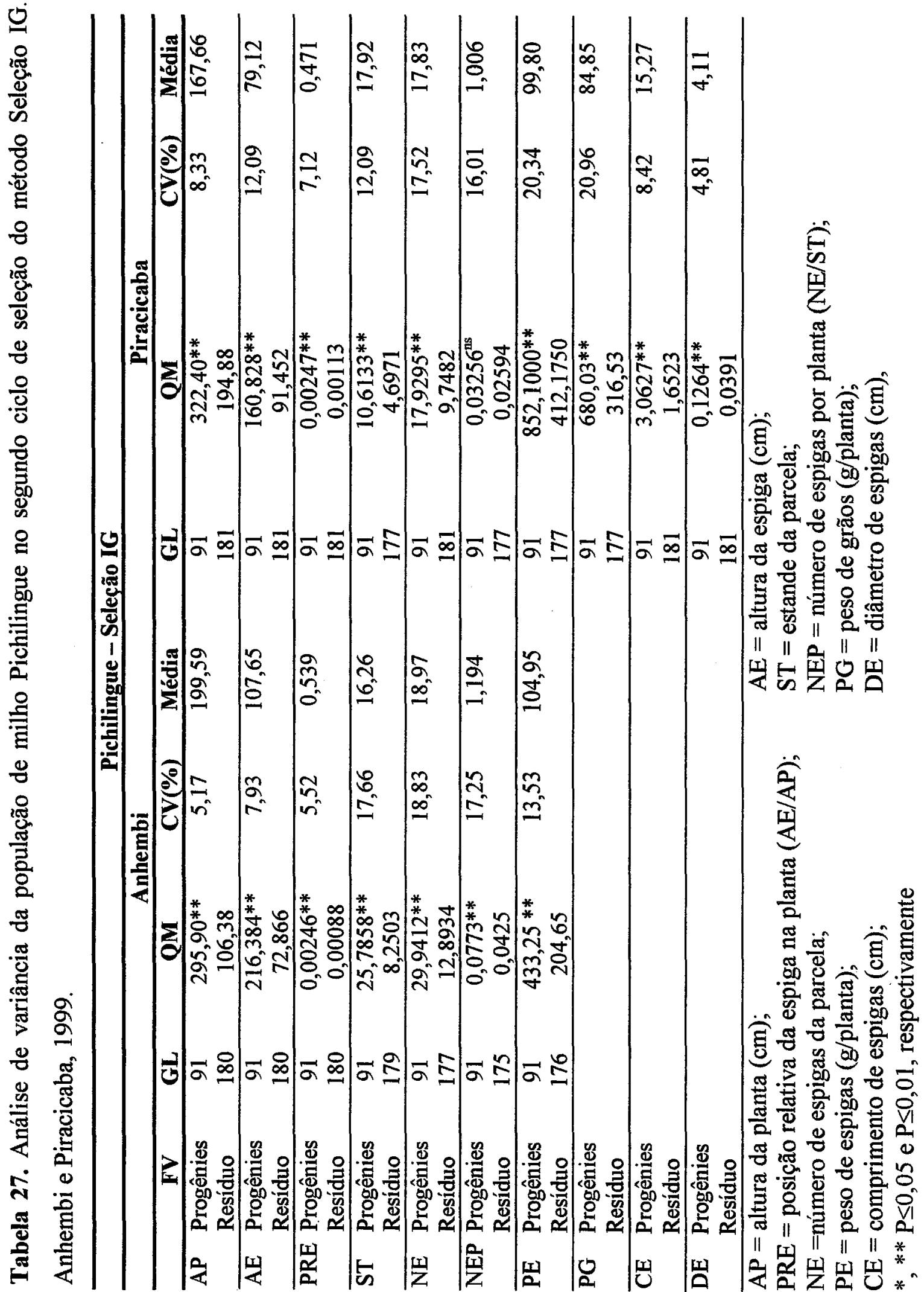




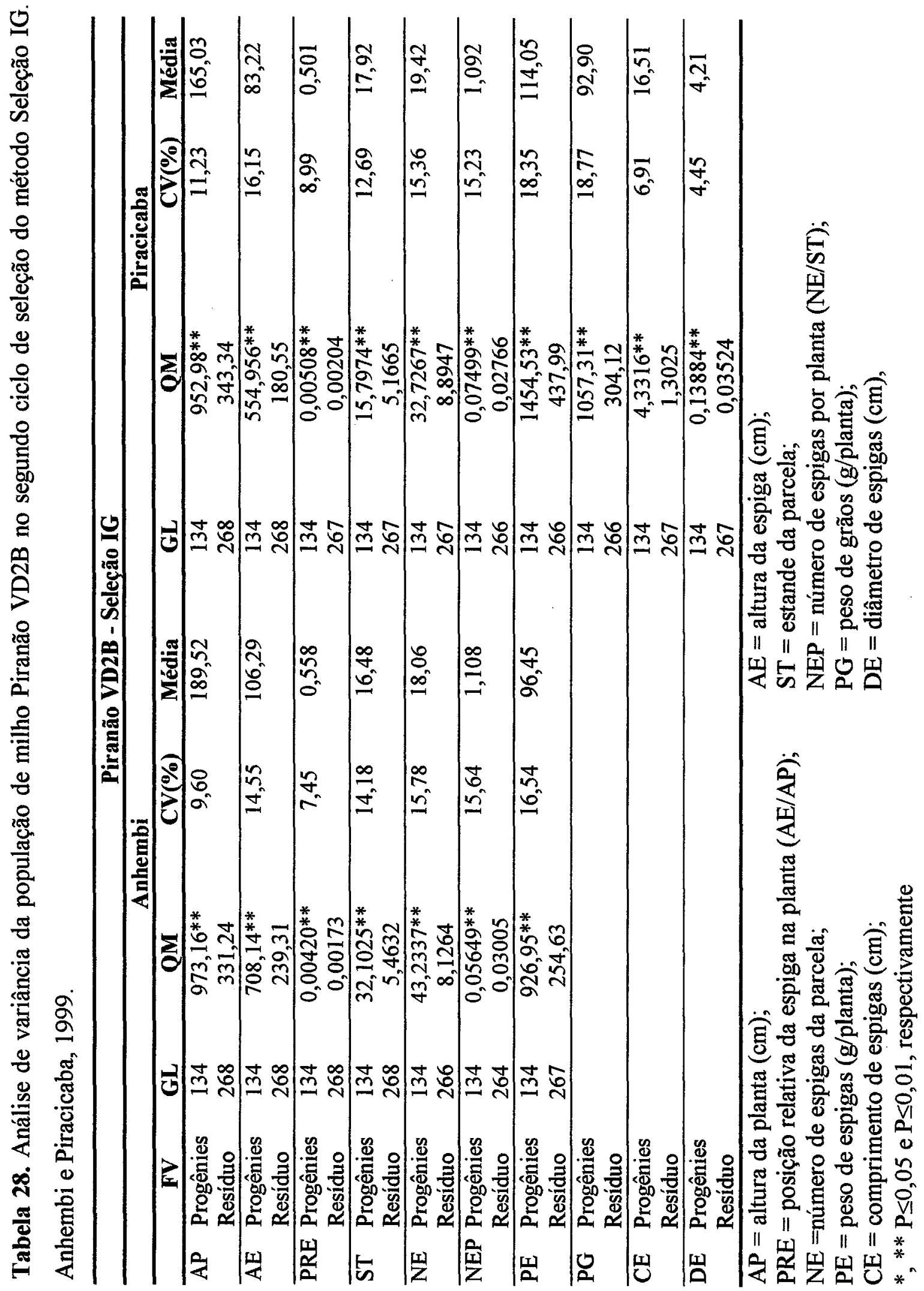




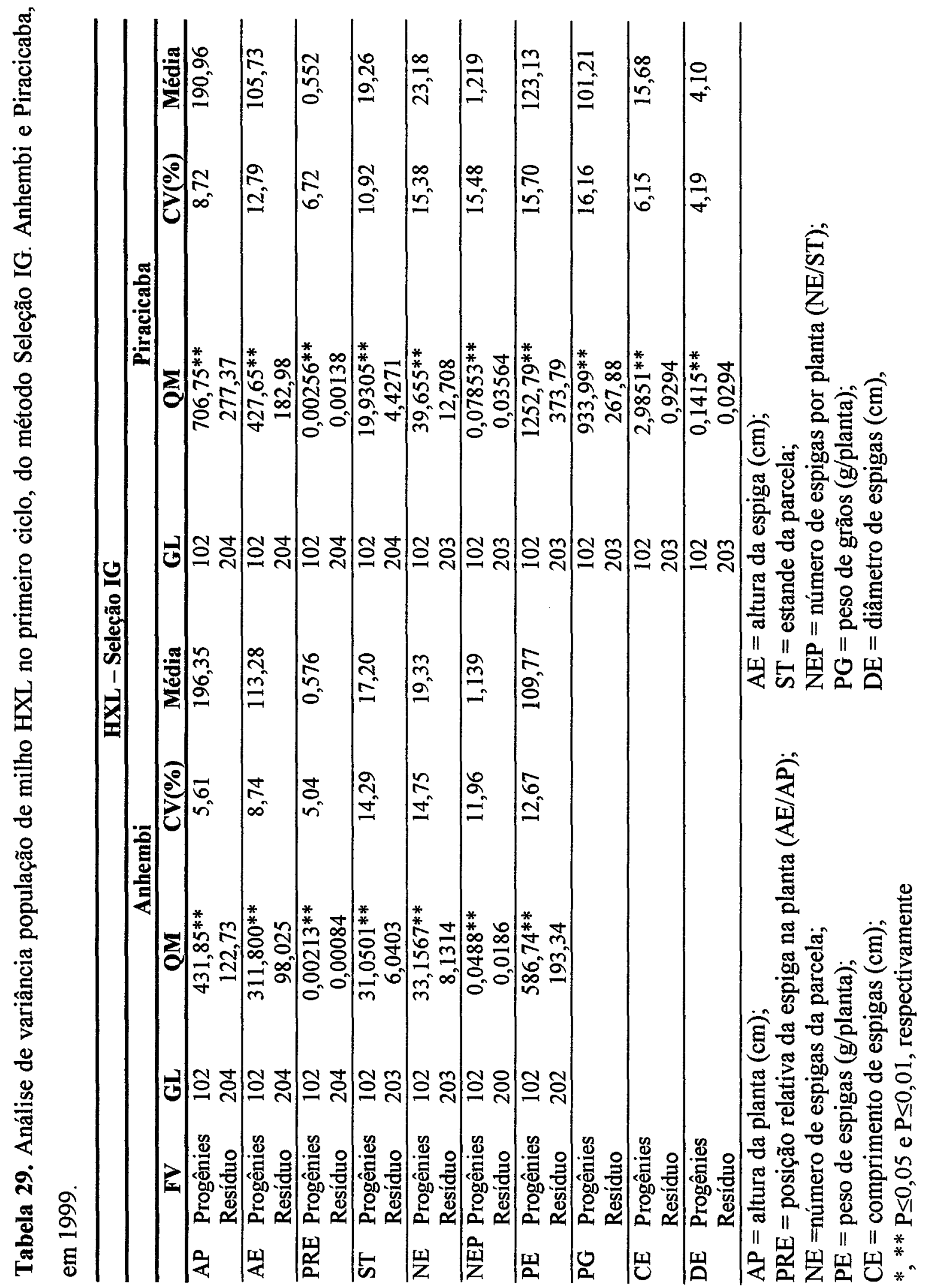




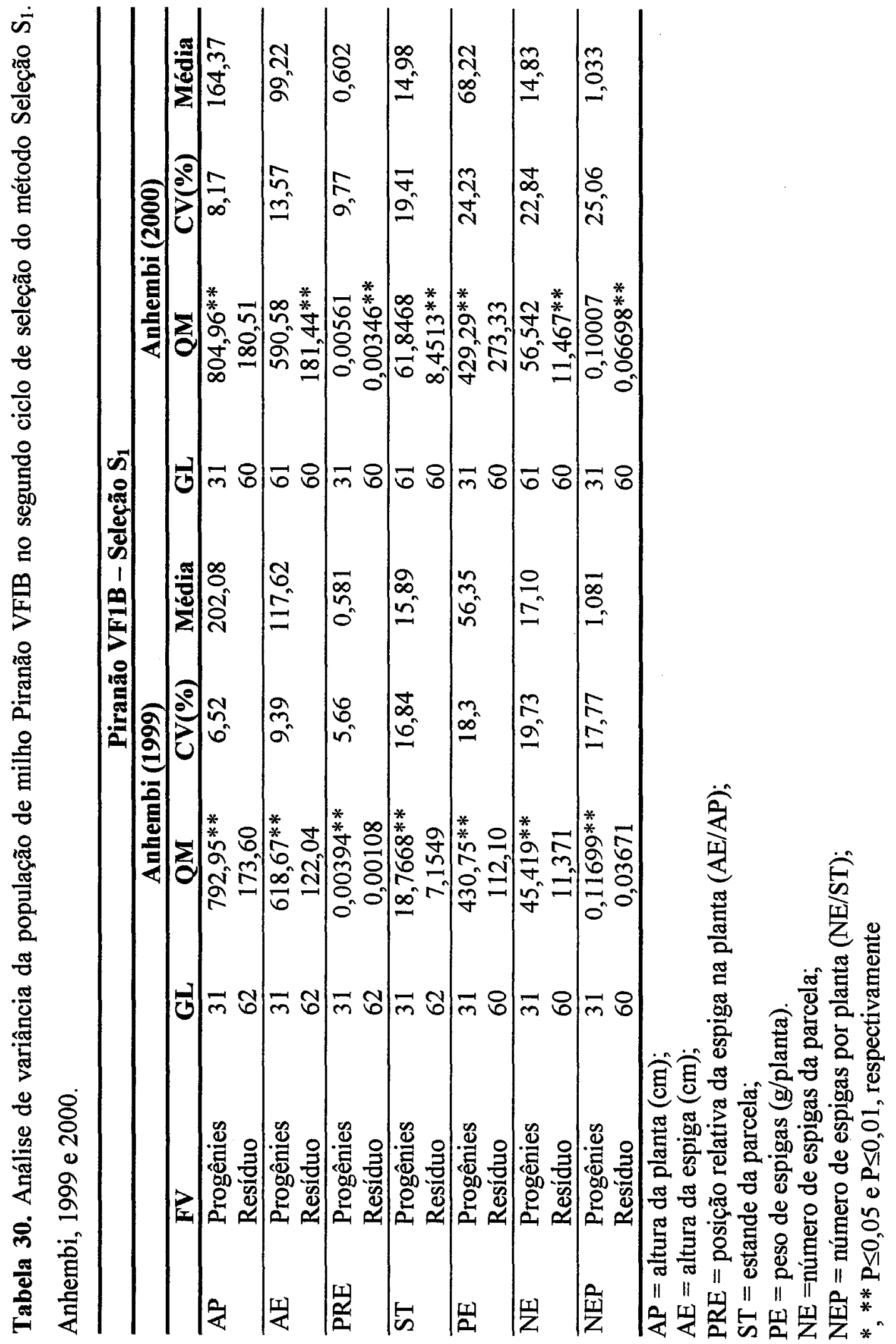




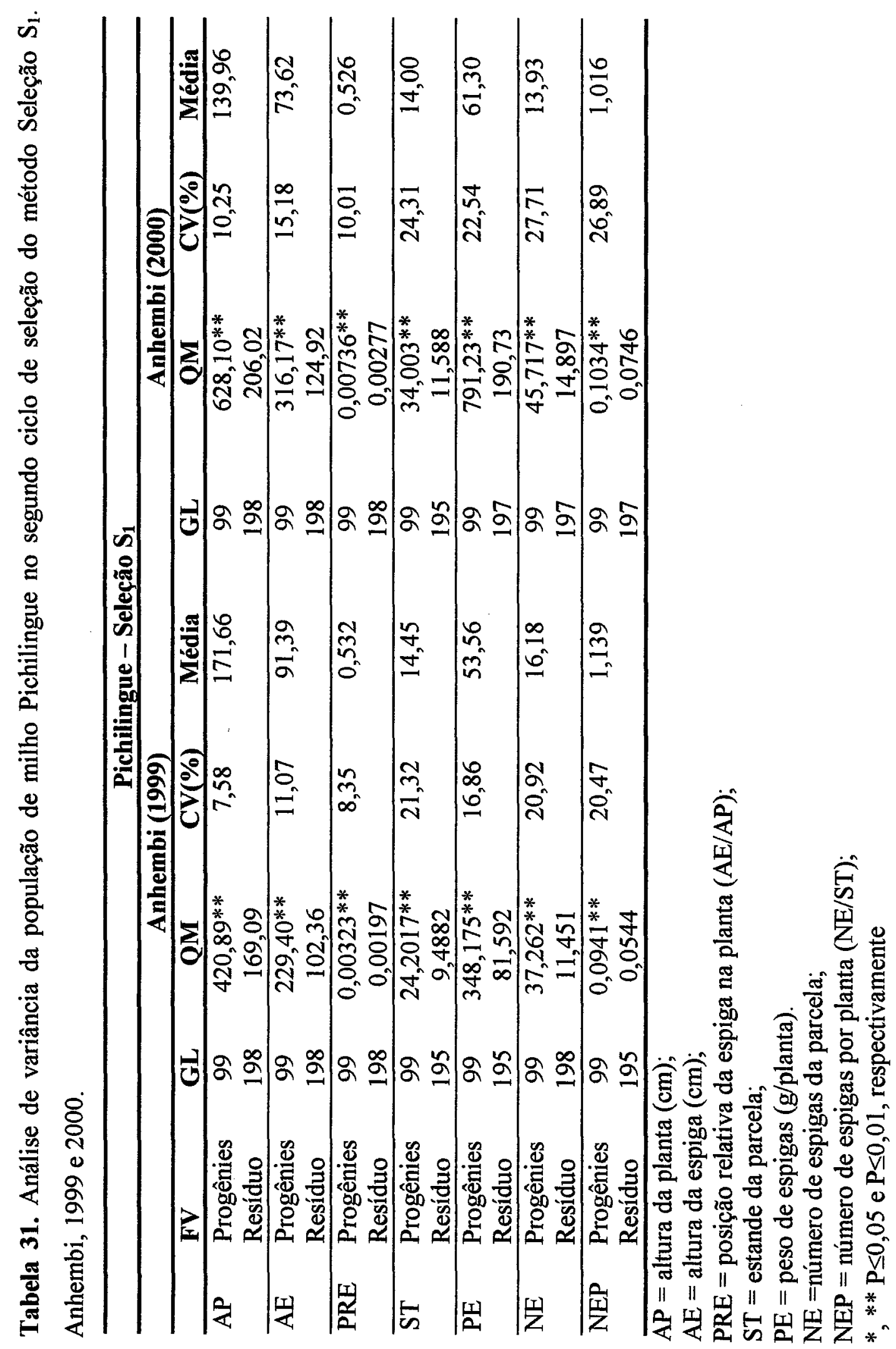




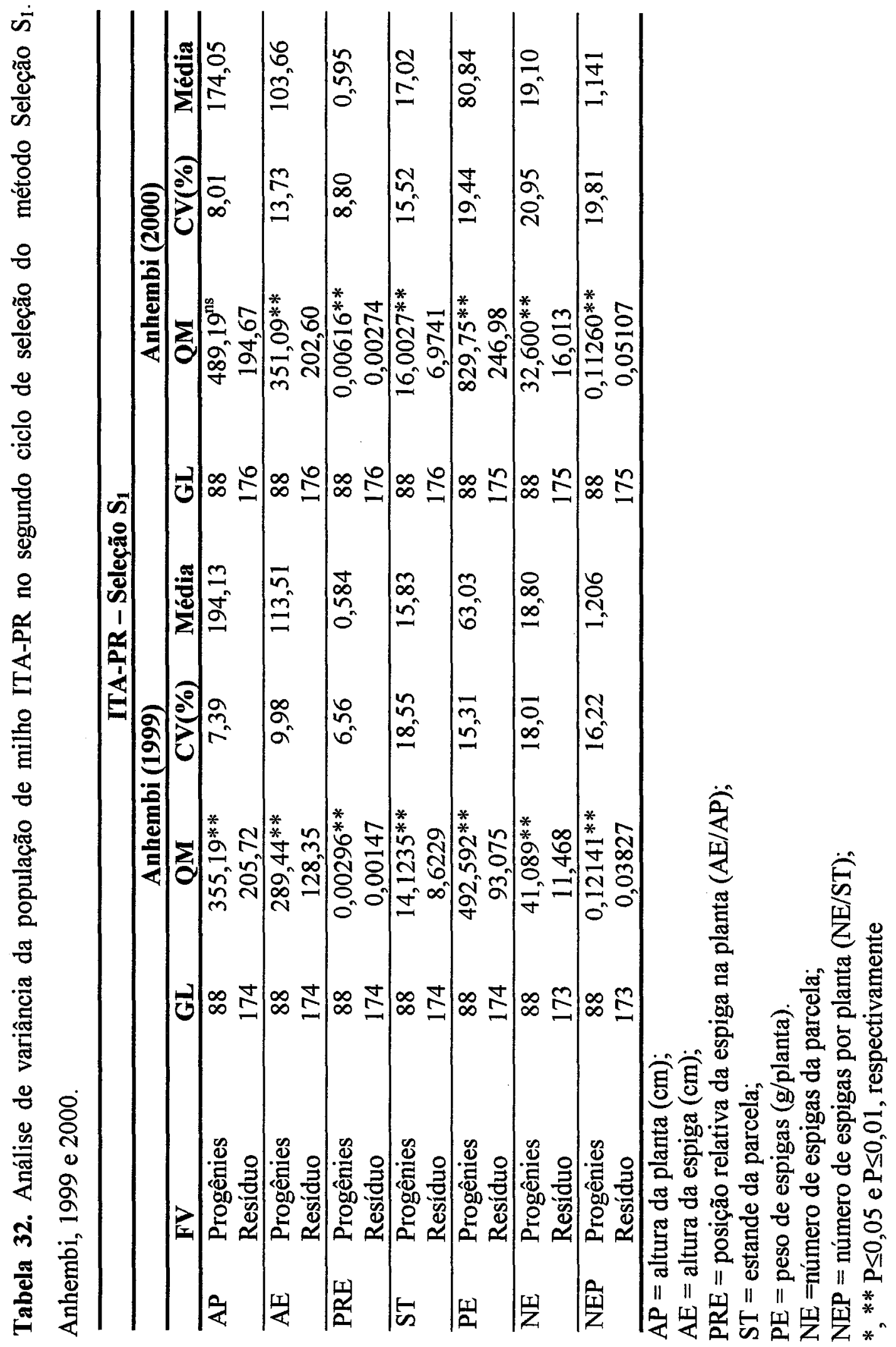




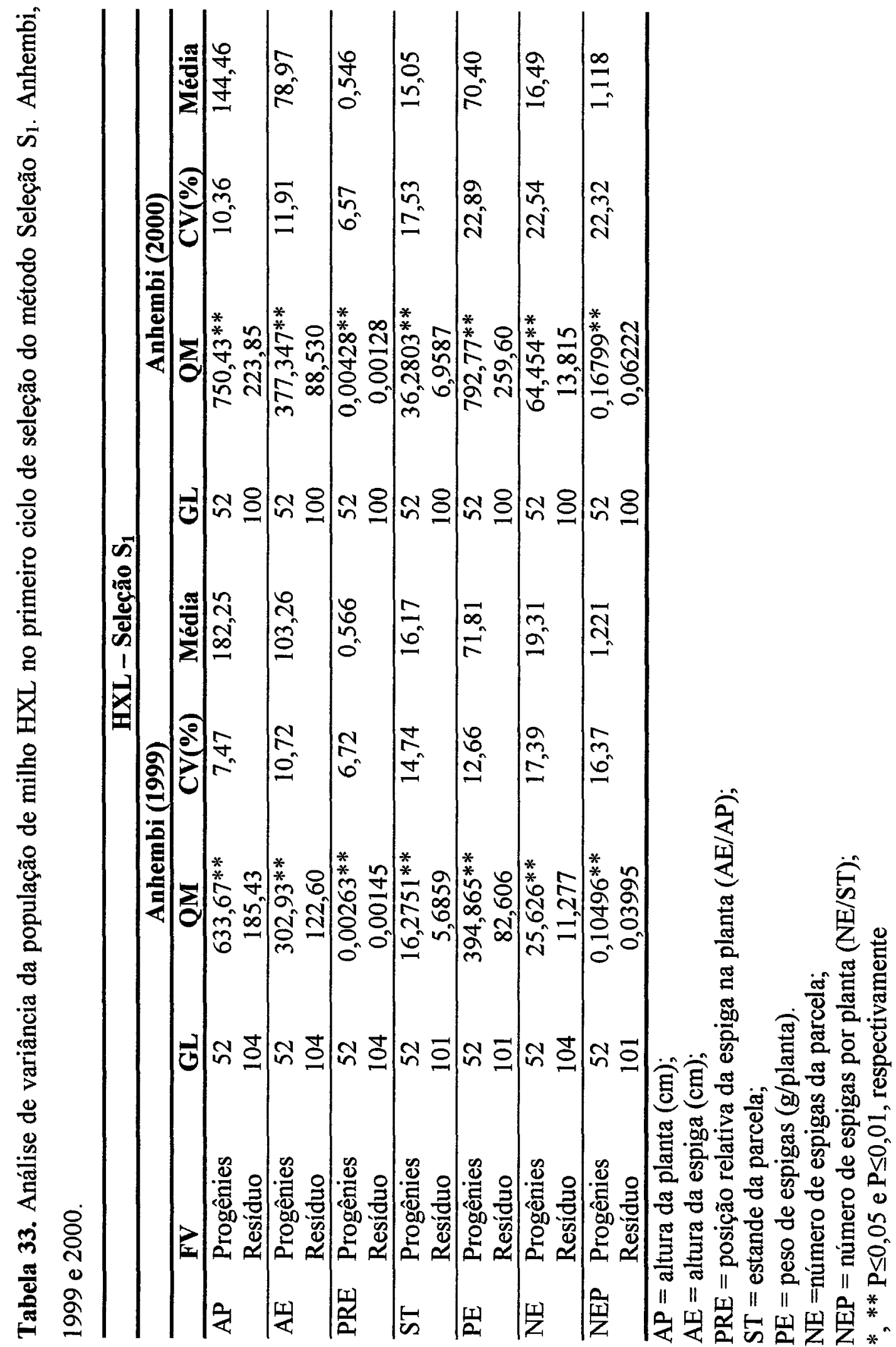




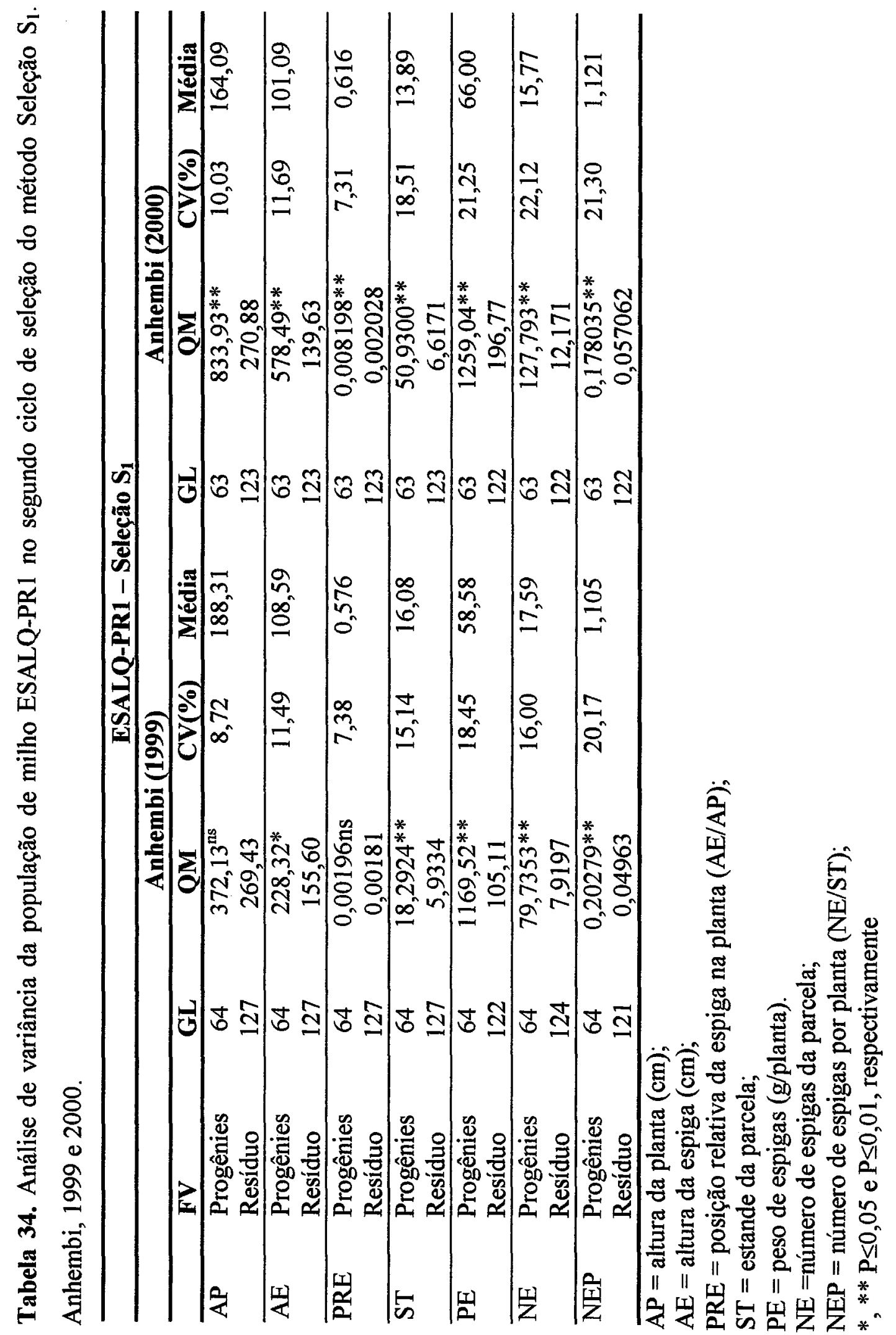




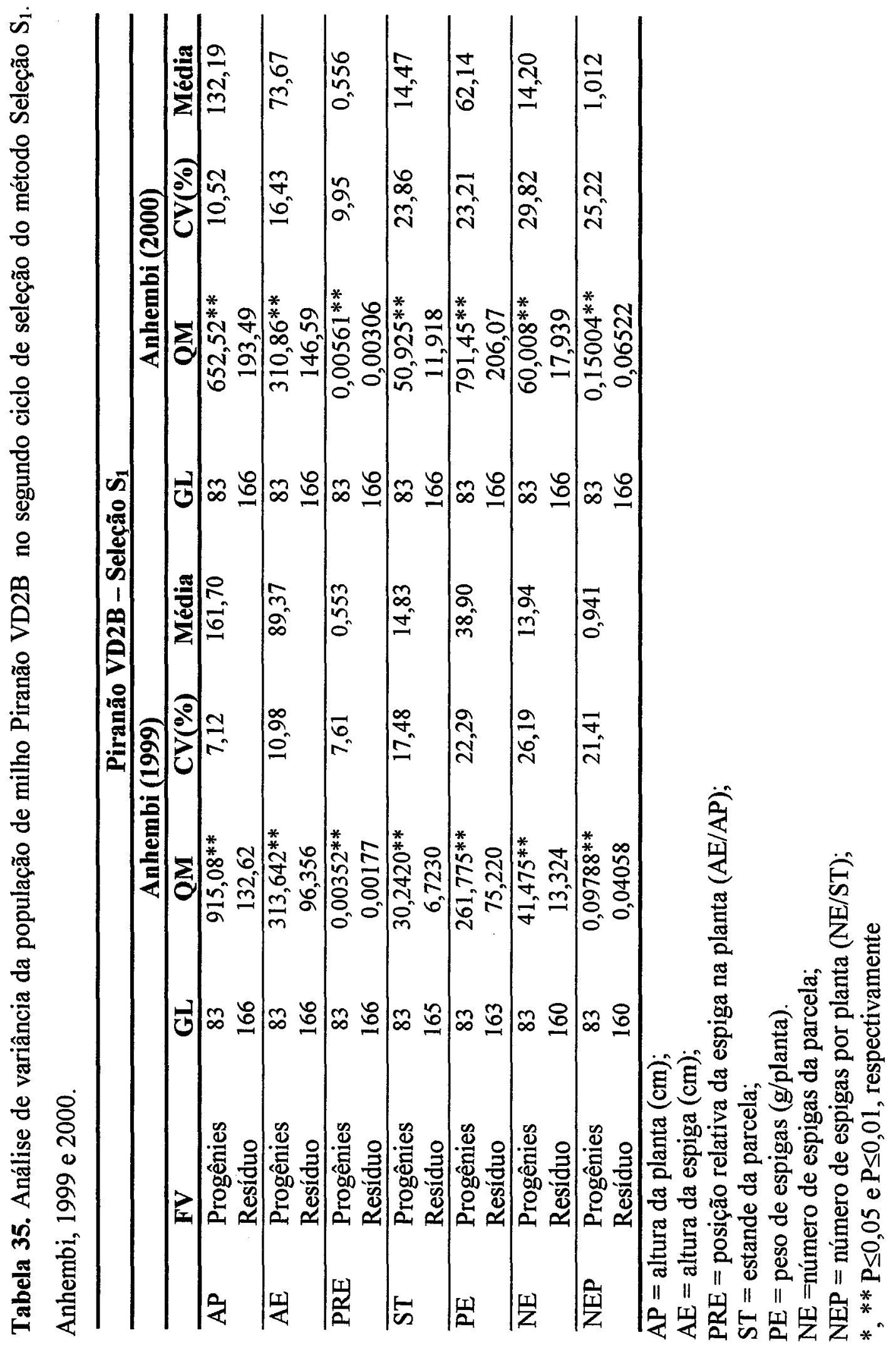


Tabela 36. Análise de variância conjunta da população de milho HXL no primeiro ciclo de seleção do método Seleção IG. Anhembi e Piracicaba, 1999.

\begin{tabular}{|c|c|c|c|c|}
\hline FV & $\mathbf{G L}$ & $\mathbf{Q M}$ & $\% \mathrm{CV}$ & Média \\
\hline \multicolumn{5}{|c|}{ Altura da Planta $(\mathrm{cm})$} \\
\hline Local & 1 & $4489,75^{* *}$ & 7,30 & 193,65 \\
\hline Bloco (Local) & 4 & $604,61^{*}$ & & \\
\hline Progênies & 102 & $882,90^{* *}$ & & \\
\hline Progênies $\mathrm{x}$ local & 102 & $255,69^{*}$ & & \\
\hline Resíduo médio & 408 & 200,05 & & \\
\hline \multicolumn{5}{|c|}{ Altura da Espiga $(\mathrm{cm})$} \\
\hline Local & 1 & $8801,22 * *$ & 10,82 & 109,51 \\
\hline Bloco (Local) & 4 & $367,91^{*}$ & & \\
\hline Progênies & 102 & $592,98^{* *}$ & & \\
\hline Progênies $\mathrm{x}$ local & 102 & $146,47^{\mathrm{ns}}$ & & \\
\hline Resíduo médio & 408 & 140,50 & & \\
\hline \multicolumn{5}{|c|}{ Posição da Espiga na Planta } \\
\hline Local & 1 & $0,08945^{* *}$ & 5,91 & 0,564 \\
\hline Bloco (Local) & 4 & $0,00178^{\text {ns }}$ & & \\
\hline Progênies & 102 & $0,00364 * *$ & & \\
\hline Progênies $\mathrm{x}$ local & 102 & $0,00105^{\mathrm{ns}}$ & & \\
\hline Resíduo médio & 408 & 0,00111 & & \\
\hline \multicolumn{5}{|l|}{ Estande } \\
\hline Local & 1 & $672,0952 * *$ & 12,54 & 18,24 \\
\hline Bloco (Local) & 4 & $10,6706^{\mathrm{ss}}$ & & \\
\hline Progênies & 102 & $43,3874^{* *}$ & & \\
\hline Progênies $\mathrm{x}$ local & 102 & $7,4593^{* *}$ & & \\
\hline Resíduo médio & 407 & 5,2317 & & \\
\hline \multicolumn{5}{|c|}{ Peso de Espigas (g/planta) } \\
\hline Local & 1 & $27454,22^{* *}$ & 14,46 & 116,46 \\
\hline Bloco (Local) & 4 & $1642,42^{* *}$ & & \\
\hline Progênies & 102 & $1418,92^{* *}$ & & \\
\hline Progênies $x$ local & 102 & $420,33^{* *}$ & & \\
\hline Resíduo médio & 405 & 283,79 & & \\
\hline \multicolumn{5}{|c|}{ Número de Espigas da Parcela } \\
\hline Local & 1 & $2319,730^{* *}$ & 15,19 & 21,26 \\
\hline Bloco (Local) & 4 & $24,722^{\mathrm{ns}}$ & & \\
\hline Progênies & 102 & $57,254 * *$ & & \\
\hline Progênies $\mathrm{x}$ local & 102 & $15,294^{* *}$ & & \\
\hline Resíduo médio & 406 & 10,420 & & \\
\hline \multicolumn{5}{|c|}{ Número de Espigas/Planta } \\
\hline Local & 1 & $0,94888^{* *}$ & 13,97 & 1,179 \\
\hline Bloco (Local) & 4 & $0,12443 * *$ & & \\
\hline Progênies & 102 & $0,08882 * *$ & & \\
\hline Progênies x local & 102 & $0,03722 *$ & & \\
\hline Resíduo médio & 403 & 0,02716 & & \\
\hline
\end{tabular}

*, ** $\mathrm{P} \leq 0,05$ e $\mathrm{P} \leq 0,01$, respectivamente. 
Tabela 37. Análise de variância conjunta da população de milho ITA-PR no segundo ciclo de seleção do método Seleção IG. Anhembi e Piracicaba, 1999.

\begin{tabular}{|c|c|c|c|c|}
\hline FV & GL & QM & $\% \mathrm{CV}$ & Média \\
\hline \multicolumn{5}{|c|}{ Altura da planta $(\mathrm{cm})$} \\
\hline Local & 1 & $84000,19 * *$ & 6,72 & 213,82 \\
\hline Bloco (Local) & 4 & $2028,79 * *$ & & \\
\hline Progênies & 121 & $842,83^{* *}$ & & \\
\hline Progênies $\mathrm{x}$ local & 121 & $273,05^{*}$ & & \\
\hline Resíduo médio & 483 & 206,20 & & \\
\hline \multicolumn{5}{|c|}{ Altura da Espiga (cm) } \\
\hline Local & 1 & $131124,99^{* *}$ & 9,16 & 120,80 \\
\hline Bloco (Local) & 4 & $1118,03 * *$ & & \\
\hline Progênies & 121 & $563,46 * *$ & & \\
\hline Progênies x local & 121 & $168,21 * *$ & & \\
\hline Resíduo médio & 483 & 122,35 & & \\
\hline \multicolumn{5}{|c|}{ Posição da Espiga na Planta } \\
\hline Local & 1 & $0,86864 * *$ & 5,31 & 0,563 \\
\hline Bloco (Local) & 4 & $0,00263^{*}$ & & \\
\hline Progênies & 121 & $0,00433 * *$ & & \\
\hline Progênies $\mathrm{x}$ local & 121 & $0,00103^{\text {ns }}$ & & \\
\hline Resíduo médio & 482 & 0,00089 & & \\
\hline \multicolumn{5}{|l|}{ Estande } \\
\hline Local & 1 & $507,6378 * *$ & 11,44 & 18,24 \\
\hline Bloco (Local) & 4 & $27,2863 * *$ & & \\
\hline Progênies & 121 & $14,2613^{* *}$ & & \\
\hline Progênies $\mathrm{x}$ local & 121 & $6,3131^{* *}$ & & \\
\hline Resíduo médio & 471 & 4,3582 & & \\
\hline \multicolumn{5}{|c|}{ Peso de Espigas (g/planta) } \\
\hline Local & 1 & $7691,80^{* *}$ & 15,81 & 108,79 \\
\hline Bloco (Local) & 4 & $3383,02 * *$ & & \\
\hline Progênies & 121 & $1795,28 * *$ & & \\
\hline Progênies x local & 121 & $469,35^{* *}$ & & \\
\hline Resíduo médio & 469 & 295,81 & & \\
\hline \multicolumn{5}{|c|}{ Número de Espigas da Parcela } \\
\hline Local & 1 & $59,4084^{* *}$ & 13,13 & 20,16 \\
\hline Bloco (Local) & 4 & $14,1953^{\text {ns }}$ & & \\
\hline Progênies & 121 & $31,9678^{* *}$ & & \\
\hline Progênies x local & 121 & $8,7732^{\text {ns }}$ & & \\
\hline Resíduo médio & 480 & 7,0057 & & \\
\hline \multicolumn{5}{|c|}{ Número de Espigas / Planta } \\
\hline Local & 1 & $1,53278^{* *}$ & 15,24 & 1,119 \\
\hline Bloco (Local) & 4 & $0,19478^{* *}$ & & \\
\hline Progênies & 121 & $0,06138 * *$ & & \\
\hline Progênies $x$ local & 121 & $0,03821^{*}$ & & \\
\hline Resíduo médio & 468 & 0,02908 & & \\
\hline
\end{tabular}

*, ${ }^{* *} \mathrm{P} \leq 0,05$ e $\mathrm{P} \leq 0,01$, respectivamente. 
Tabela 38. Análise de variância conjunta da população de milho Pichilingue no segundo ciclo de seleção do método Seleção IG. Anhembi e Piracicaba, 1999.

\begin{tabular}{|c|c|c|c|c|}
\hline FV & GL & $\mathbf{Q M}$ & $\% \mathrm{CV}$ & Média \\
\hline \multicolumn{5}{|c|}{ Altura da Planta (cm) } \\
\hline Local & 1 & $140000,68 * *$ & 6,69 & 183,59 \\
\hline Bloco (Local) & 4 & $5337,30^{* *}$ & & \\
\hline Progênies & 91 & $443,81^{* *}$ & & \\
\hline Progênies $\mathrm{x}$ local & 91 & $173,88^{\text {ns }}$ & & \\
\hline Resíduo médio & 361 & 150,75 & & \\
\hline \multicolumn{5}{|c|}{ Altura da Espiga (cm) } \\
\hline Local & 1 & $111929,171^{* *}$ & 9,71 & 93,36 \\
\hline Bloco (Local) & 4 & $2368,802^{* *}$ & & \\
\hline Progênies & 91 & $273,581^{* *}$ & & \\
\hline Progênies $\mathrm{x}$ local & 91 & $103,239^{\text {ns }}$ & & \\
\hline Resíduo médio & 361 & 82,185 & & \\
\hline \multicolumn{5}{|c|}{ Posição da Espiga na Planta } \\
\hline Local & 1 & $0,63495^{* *}$ & 6,28 & 0,505 \\
\hline Bloco (Local) & 4 & $0,00496 * *$ & & \\
\hline Progênies & 91 & $0,00382 * *$ & & \\
\hline Progênies $\mathrm{x}$ local & 91 & $0,00111^{\mathrm{ns}}$ & & \\
\hline Resíduo médio & 361 & 0,00101 & & \\
\hline \multicolumn{5}{|l|}{ Estande } \\
\hline Local & 1 & $369,0591^{* *}$ & 14,90 & 17,09 \\
\hline Bloco (Local) & 4 & $37,2435^{* *}$ & & \\
\hline Progênies & 91 & $28,9708^{* *}$ & & \\
\hline Progênies x local & 91 & $7,3291^{\text {ns }}$ & & \\
\hline Resíduo médio & 356 & 6,4837 & & \\
\hline \multicolumn{5}{|c|}{ Peso de Espigas (gramas/parcela) } \\
\hline Local & 1 & $3144,09^{* *}$ & 17,16 & 102,38 \\
\hline Bloco (Local) & 4 & $21942,16^{* *}$ & & \\
\hline Progênies & 91 & $850,71^{* *}$ & & \\
\hline Progênies $\mathrm{x}$ local & 91 & $449,66^{* *}$ & & \\
\hline Resíduo médio & 353 & 308,71 & & \\
\hline \multicolumn{5}{|c|}{ Número de Espigas da Parcela } \\
\hline Local & 1 & $177,959 * *$ & 18,28 & 18,39 \\
\hline Bloco (Local) & 4 & $123,532 * *$ & & \\
\hline Progênies & 91 & $34,979 * *$ & & \\
\hline Progênies x local & 91 & $12,976^{* *}$ & & \\
\hline Resíduo médio & 358 & 11,303 & & \\
\hline \multicolumn{5}{|c|}{ Número de Espigas / Planta } \\
\hline Local & 1 & $5,10191^{* *}$ & 16,80 & 1,100 \\
\hline Bloco (Local) & 4 & $0,54829 * *$ & & \\
\hline Progênies & 91 & $0,06270^{* *}$ & & \\
\hline Progênies x local & 91 & $0,05347^{* *}$ & & \\
\hline Resíduo médio & 352 & 0,03415 & & \\
\hline
\end{tabular}

$*{ }^{* *} \mathrm{P} \leq 0,05$ e $\mathrm{P} \leq 0,01$, respectivamente. 
Tabela 39. Análise de variância conjunta da população de milho Piranão VF1B no segundo ciclo de seleção do método Seleção IG. Anhembi e Piracicaba, 1999.

\begin{tabular}{|c|c|c|c|c|}
\hline $\mathbf{F V}$ & GL & $\mathbf{Q M}$ & $\% \mathrm{CV}$ & Média \\
\hline \multicolumn{5}{|c|}{ Altura da Planta (cm) } \\
\hline Local & 1 & $131207,02^{* *}$ & 6,65 & 211,96 \\
\hline Bloco (Local) & 4 & $4345,47^{* *}$ & & \\
\hline Progênies & 80 & $1234,66^{* *}$ & & \\
\hline Progênies $\mathrm{x}$ local & 80 & $197,25^{\text {ns }}$ & & \\
\hline Resíduo médio & 320 & 198,81 & & \\
\hline \multicolumn{5}{|c|}{ Altura da Espiga (cm) } \\
\hline Local & 1 & $136507,52^{* *}$ & 9,84 & 125,04 \\
\hline Bloco (Local) & 4 & $2258,85^{* *}$ & & \\
\hline Progênies & 80 & $957,40^{* *}$ & & \\
\hline Progênies $x$ local & 80 & $135,20^{\mathrm{ns}}$ & & \\
\hline Resíduo médio & 320 & 151,43 & & \\
\hline \multicolumn{5}{|c|}{ Posição da Espiga na Planta } \\
\hline Local & 1 & $0,55957^{* *}$ & 5,69 & 0,586 \\
\hline Bloco (Local) & 4 & $0,00566^{* *}$ & & \\
\hline Progênies & 80 & $0,00519 * *$ & & \\
\hline Progênies $x$ local & 80 & $0,00113^{\text {ns }}$ & & \\
\hline Resíduo médio & 320 & 0,00111 & & \\
\hline \multicolumn{5}{|l|}{ Estande } \\
\hline Local & 1 & $2,7076^{\mathrm{ns}}$ & 15,37 & 16,83 \\
\hline Bloco (Local) & 4 & $38,4783^{* *}$ & & \\
\hline Progênies & 80 & $18,0228^{* *}$ & & \\
\hline Progênies $\mathrm{x}$ local & 80 & $7,5046^{\mathrm{ns}}$ & & \\
\hline Resíduo médio & 317 & 6,6922 & & \\
\hline \multicolumn{5}{|c|}{ Peso de Espigas (g/planta) } \\
\hline Local & 1 & $78762,77^{* *}$ & 16,16 & 113,03 \\
\hline Bloco (Local) & 4 & $4189,21^{* *}$ & & \\
\hline Progênies & 80 & $2697,16^{* *}$ & & \\
\hline Progênies $\mathrm{x}$ local & 80 & $342,85^{\text {ns }}$ & & \\
\hline Resíduo médio & 315 & 333,76 & & \\
\hline \multicolumn{5}{|c|}{ Número de Espigas da Parcela } \\
\hline Local & 1 & $142,112^{* *}$ & 16,39 & 20,30 \\
\hline Bloco (Local) & 4 & $7,0327^{\mathrm{ns}}$ & & \\
\hline Progênies & 80 & $53,030^{* *}$ & & \\
\hline Progênies $x$ local & 80 & $12,234^{\text {ns }}$ & & \\
\hline Resíduo médio & 318 & 11,065 & & \\
\hline \multicolumn{5}{|c|}{ Número de Espigas / Planta } \\
\hline Local & 1 & $0,19015^{\text {1s }}$ & 19,66 & 1,222 \\
\hline Bloco (Local) & 4 & $0,18680^{* *}$ & & \\
\hline Progênies & 80 & $0,08694^{* *}$ & & \\
\hline Progênies $x$ local & 80 & $0,04833^{\text {ns }}$ & & \\
\hline Resíduo médio & 315 & 0,05770 & & \\
\hline
\end{tabular}

${ }^{*},{ }^{* *} \mathrm{P} \leq 0,05$ e $\mathrm{P} \leq 0,01$, respectivamente. 
Tabela 40. Análise de variância conjunta da população de milho Piranão VF1B-P no segundo ciclo de seleção do método Seleção IG. Anhembi e Piracicaba, 1999.

\begin{tabular}{|c|c|c|c|c|}
\hline FV & GL & $\mathbf{Q M}$ & $\% \mathrm{CV}$ & Média \\
\hline \multicolumn{5}{|c|}{ Altura da Planta (cm) } \\
\hline Local & 1 & $276289,26^{* *}$ & 9,27 & 198,16 \\
\hline Bloco (Local) & 4 & $2811,43^{* *}$ & & \\
\hline Progênies & 109 & $1783,06^{* *}$ & & \\
\hline Progênies $x$ local & 109 & $316,12^{\text {ns }}$ & & \\
\hline Resíduo médio & 434 & 337,52 & & \\
\hline \multicolumn{5}{|c|}{ Altura da Espiga (cm) } \\
\hline Local & 1 & $206749,77^{* *}$ & 12,58 & 112,95 \\
\hline Bloco (Local) & 4 & $2701,50 * *$ & & \\
\hline Progênies & 109 & $1034,86^{* *}$ & & \\
\hline Progênies x local & 109 & $230,44^{\text {ns }}$ & & \\
\hline Resíduo médio & 434 & 204,64 & & \\
\hline \multicolumn{5}{|c|}{ Posição da Espiga na Planta } \\
\hline Local & 1 & $0,59432^{* *}$ & 6,97 & 0,569 \\
\hline Bloco (Local) & 4 & $0,01424^{* *}$ & & \\
\hline Progênies & 109 & $0,00565^{* *}$ & & \\
\hline Progênies $\mathrm{x}$ local & 109 & $0,00175^{\text {ns }}$ & & \\
\hline Resíduo médio & 434 & 0,00157 & & \\
\hline \multicolumn{5}{|l|}{ Estande } \\
\hline Local & 1 & $4,4927^{\text {ns }}$ & 14,73 & 16,15 \\
\hline Bloco (Local) & 4 & $8,9928^{\text {ns }}$ & & \\
\hline Progênies & 109 & $31,5164^{* *}$ & & \\
\hline Progênies $x$ local & 109 & $7,2081^{* *}$ & & \\
\hline Resíduo médio & 434 & 5,6571 & & \\
\hline \multicolumn{5}{|c|}{ Peso de Grãos (g/planta) } \\
\hline Local & 1 & $2191,03^{*}$ & 19,60 & 103,40 \\
\hline Bloco (Local) & 4 & $7095,98^{* *}$ & & \\
\hline Progênies & 109 & $1639,83^{* *}$ & & \\
\hline Progênies $\mathrm{x}$ local & 109 & $500,08^{\text {ns }}$ & & \\
\hline Resíduo médio & 434 & 411,43 & & \\
\hline \multicolumn{5}{|c|}{ Número de Espigas da Parcela } \\
\hline Local & 1 & $24,922^{\text {ns }}$ & 17,86 & 19,51 \\
\hline Bloco (Local) & 4 & $122,650^{* *}$ & & \\
\hline Progênies & 109 & $58,406^{* *}$ & & \\
\hline Progênies x local & 109 & $15,146^{\text {ns }}$ & & \\
\hline Residuo médio & 434 & 12,135 & & \\
\hline \multicolumn{5}{|c|}{ Número de Espigas / Planta } \\
\hline Local & 1 & $0,09222^{\mathrm{ns}}$ & 16,51 & 1,221 \\
\hline Bloco (Local) & 4 & $0,32816^{* *}$ & & \\
\hline Progênies & 109 & $0,09131^{* *}$ & & \\
\hline Progênies $\mathrm{x}$ local & 109 & $0,05189^{*}$ & & \\
\hline Resíduo médio & 434 & 0,04062 & & \\
\hline
\end{tabular}

$*, * * \mathrm{P} \leq 0,05$ e $\mathrm{P} \leq 0,01$, respectivamente. 
Tabela 41. Análise de variância conjunta da população de milho Piranão VD2B no segundo ciclo de seleção do método Seleção IG. Anhembi e Piracicaba, 1999.

\begin{tabular}{|c|c|c|c|c|}
\hline FV & GL & $\mathbf{Q M}$ & $\% \mathrm{CV}$ & Média \\
\hline \multicolumn{5}{|c|}{ Altura da Planta $(\mathrm{cm})$} \\
\hline Local & 1 & $121469,79^{* *}$ & 10,36 & 177,28 \\
\hline Bloco (Local) & 4 & $642,74^{\mathrm{ns}}$ & & \\
\hline Progênies & 134 & $1589,47 * *$ & & \\
\hline Progênies x local & 134 & $336,67^{\text {ns }}$ & & \\
\hline Resíduo médio & 536 & 337,29 & & \\
\hline \multicolumn{5}{|c|}{ Altura da Espiga $(\mathrm{cm})$} \\
\hline Local & 1 & $107834,38^{* *}$ & 15,29 & 94,75 \\
\hline Bloco (Local) & 4 & $147,26^{\mathrm{ns}}$ & & \\
\hline Progênies & 134 & $1029,98^{* *}$ & & \\
\hline Progênies $\mathrm{x}$ local & 134 & $233,11^{\mathrm{ns}}$ & & \\
\hline Resíduo médio & 536 & 209,93 & & \\
\hline \multicolumn{5}{|c|}{ Posicão da Espiga na Planta } \\
\hline Local & 1 & $0,64660^{* *}$ & 8,18 & 0,530 \\
\hline Bloco (Local) & 4 & $0,00114^{\mathrm{ns}}$ & & \\
\hline Progênies & 134 & $0,00725^{* *}$ & & \\
\hline Progênies x local & 134 & $0,00202^{\text {ns }}$ & & \\
\hline Resíduo médio & 535 & 0,00188 & & \\
\hline \multicolumn{5}{|l|}{ Estande } \\
\hline Local & 1 & $415,0795^{* *}$ & 13,41 & 17,20 \\
\hline Bloco (Local) & 4 & $23,7696^{* *}$ & & \\
\hline Progênies & 134 & $38,2539 * *$ & & \\
\hline Progênies $x$ local & 134 & $9,6199 * *$ & & \\
\hline Resíduo médio & 535 & 5,3151 & & \\
\hline \multicolumn{5}{|c|}{ Peso de Espigas (g/planta) } \\
\hline Local & 1 & $60911,11 * *$ & 17,68 & 105,24 \\
\hline Bloco (Local) & 4 & $2343,59 * *$ & & \\
\hline Progênies & 134 & $1879,12^{* *}$ & & \\
\hline Progênies x local & 134 & $502,95^{* *}$ & & \\
\hline Resíduo médio & 533 & 346,13 & & \\
\hline \multicolumn{5}{|c|}{ Número de Espigas da Parcela } \\
\hline Local & 1 & $348,4598 * *$ & 15,56 & 18,75 \\
\hline Bloco (Local) & 4 & $10,4627^{\text {ns }}$ & & \\
\hline Progênies & 134 & $64,1018 * *$ & & \\
\hline Progênies x local & 134 & $11,6258 * *$ & & \\
\hline Resíduo médio & 533 & 8,5112 & & \\
\hline \multicolumn{5}{|c|}{ Número de espigas / planta } \\
\hline Local & 1 & $0,06710^{\text {ns }}$ & 15,44 & 1,100 \\
\hline Bloco (Local) & 4 & $0,15119 * *$ & & \\
\hline Progênies & 134 & $0,09518^{* *}$ & & \\
\hline Progênies $x$ local & 134 & $0,03655^{* *}$ & & \\
\hline Resíduo médio & 530 & 0,02885 & & \\
\hline
\end{tabular}

${ }^{*}, * * \mathrm{P} \leq 0,05$ e $\mathrm{P} \leq 0,01$, respectivamente. 
Tabela 42. Análise de variância conjunta da população de milho HXL no segundo ciclo de seleção do método Seleção $S_{1}$. Anhembi, 1999 e 2000.

\begin{tabular}{|c|c|c|c|c|}
\hline FV & GL & $\mathbf{Q M}$ & $\mathrm{CV}(\%)$ & Média \\
\hline \multicolumn{5}{|c|}{ Altura da planta (cm) } \\
\hline Local & 1 & $113957,30^{* *}$ & 8,74 & 163,60 \\
\hline Bloco (Local) & 4 & $2079,84^{* *}$ & & \\
\hline Progênies & 52 & $1140,44^{* *}$ & & \\
\hline Progênies $x$ ano & 52 & $260,52^{\text {ns }}$ & & \\
\hline Resíduo médio & 204 & 204,26 & & \\
\hline \multicolumn{5}{|c|}{ Altura da espiga (cm) } \\
\hline Local & 1 & $46082,82^{* *}$ & 11,28 & 91,27 \\
\hline Bloco (Local) & 4 & $684,84^{* *}$ & & \\
\hline Progênies & 52 & $519,67^{* *}$ & & \\
\hline Progênies $\mathrm{x}$ ano & 52 & $162,86^{*}$ & & \\
\hline Resíduo médio & 204 & 105,90 & & \\
\hline \multicolumn{5}{|c|}{ Posicão da espiga na planta } \\
\hline Local & 1 & $0,028230^{* *}$ & 6,67 & 0,556 \\
\hline Bloco (Local) & 4 & $0,00067^{* *}$ & & \\
\hline Progênies & 52 & $0,00437^{* *}$ & & \\
\hline Progênies $\mathrm{x}$ ano & 52 & $0,00265^{* *}$ & & \\
\hline Resíduo médio & 204 & 0,00137 & & \\
\hline \multicolumn{5}{|l|}{ Estande } \\
\hline Local & 1 & $130,9998^{* *}$ & 16,10 & 15,61 \\
\hline Bloco (Local) & 4 & $11,4637^{\mathrm{ns}}$ & & \\
\hline Progênies & 52 & $36,5590^{* *}$ & & \\
\hline Progênies $\mathrm{x}$ ano & 52 & $18,5496 * *$ & & \\
\hline Resíduo médio & 201 & 6,3191 & & \\
\hline \multicolumn{5}{|c|}{ Peso de espigas (g/planta) } \\
\hline Local & 1 & $412,30^{\text {ns }}$ & 18,37 & 71,11 \\
\hline Bloco (Local) & 4 & $901,01^{* *}$ & & \\
\hline Progênies & 52 & $758,08^{* *}$ & & \\
\hline Progênies $\mathrm{x}$ ano & 52 & $425,97^{* *}$ & & \\
\hline Resíduo médio & 201 & 170,65 & & \\
\hline \multicolumn{5}{|c|}{ Número de espigas por parcela } \\
\hline Local & 1 & $778,117^{* *}$ & 19,75 & 17,98 \\
\hline Bloco (Local) & 4 & $68,086^{* *}$ & & \\
\hline Progênies & 52 & $62,025^{* *}$ & & \\
\hline Progênies $\mathrm{x}$ ano & 52 & $31,595^{* *}$ & & \\
\hline Resíduo médio & 204 & 12,521 & & \\
\hline \multicolumn{5}{|c|}{ Número de espigas / planta } \\
\hline Local & 1 & $0,98379 * *$ & 19,31 & 1,170 \\
\hline Bloco (Local) & 4 & $0,38306^{* *}$ & & \\
\hline Progênies & 52 & $0,19662^{* *}$ & & \\
\hline Progênies $\mathrm{x}$ ano & 52 & $0,07860^{*}$ & & \\
\hline Resíduo médio & 201 & 0,05102 & & \\
\hline
\end{tabular}

*, ** $\mathrm{P} \leq 0,05$ e $\mathrm{P} \leq 0,01$, respectivamente. 
Tabela 43. Análise de variância conjunta da população de milho ITA-PR no segundo ciclo de seleção do método Seleção $S_{1}$. Anhembi, 1999 e 2000.

\begin{tabular}{|c|c|c|c|c|}
\hline $\mathbf{F V}$ & GL & $\mathbf{Q M}$ & CV(\%) & Média \\
\hline \multicolumn{5}{|c|}{ Altura da planta $(\mathrm{cm})$} \\
\hline Local & 1 & $53667,36^{* *}$ & 7,69 & 184,05 \\
\hline Bloco (Local) & 4 & $592,58^{*}$ & & \\
\hline Progênies & 88 & $512,72 * *$ & & \\
\hline Progênies $x$ ano & 88 & $329,62^{* *}$ & & \\
\hline Resíduo médio & 350 & 200,16 & & \\
\hline \multicolumn{5}{|c|}{ Altura da espiga (cm) } \\
\hline Local & 1 & $13095,01^{* *}$ & 11,86 & 108,56 \\
\hline Bloco (Local) & 4 & $579,80^{* *}$ & & \\
\hline Progênies & 88 & $449,90 * *$ & & \\
\hline Progênies $\mathrm{x}$ ano & 88 & $188,57^{\text {ns }}$ & & \\
\hline Resíduo médio & 350 & 165,69 & & \\
\hline \multicolumn{5}{|c|}{ Posição da espiga na planta } \\
\hline Local & 1 & $0,01390^{* *}$ & 7,79 & 0,589 \\
\hline Bloco (Local) & 4 & $0,00851^{* *}$ & & \\
\hline Progênies & 88 & $0,00627^{* *}$ & & \\
\hline Progênies $\mathrm{x}$ ano & 88 & $0,00283^{*}$ & & \\
\hline Resíduo médio & 350 & 0,00210 & & \\
\hline \multicolumn{5}{|l|}{ Estande } \\
\hline Local & 1 & $186,1510^{* *}$ & 16,997 & 16,43 \\
\hline Bloco (Local) & 4 & $31,1656^{* *}$ & & \\
\hline Progênies & 88 & $20,0131^{* *}$ & & \\
\hline Progênies $\mathrm{x}$ ano & 88 & $9,9776^{\text {ns }}$ & & \\
\hline Resíduo médio & 350 & 7,7938 & & \\
\hline \multicolumn{5}{|c|}{ Peso de espigas (g/planta) } \\
\hline Local & 1 & $41261,64^{* *}$ & 18,13 & 71,95 \\
\hline Bloco (Local) & 4 & $917,94^{* *}$ & & \\
\hline Progênies & 88 & $919,03^{* *}$ & & \\
\hline Progênies $\mathrm{x}$ ano & 88 & $400,51^{* *}$ & & \\
\hline Resíduo médio & 349 & 170,25 & & \\
\hline \multicolumn{5}{|c|}{ Número de espigas da parcela } \\
\hline Local & 1 & $6,551^{\text {ns }}$ & 19,57 & 18,95 \\
\hline Bloco (Local) & 4 & $15,577^{\text {ns }}$ & & \\
\hline Progênies & 88 & $54,517 * *$ & & \\
\hline Progênies $x$ ano & 88 & $20,008 * *$ & & \\
\hline Resíduo médio & 348 & 13,753 & & \\
\hline \multicolumn{5}{|c|}{ Número de espigas / planta } \\
\hline Local & 1 & $0,62121^{* *}$ & 18,02 & 1,173 \\
\hline Bloco (Local) & 4 & $0,14603^{*}$ & & \\
\hline Progênies & 88 & $0,15281^{* *}$ & & \\
\hline Progênies $x$ ano & 88 & $0,08256^{* *}$ & & \\
\hline Resíduo médio & 348 & 0,04470 & & \\
\hline
\end{tabular}

${ }^{*},{ }^{* *} \mathrm{P} \leq 0,05$ e $\mathrm{P} \leq 0,01$, respectivamente. 
Tabela 44. Análise de variância conjunta da população de milho Pichilingue no segundo ciclo de seleção do método Seleção $S_{1}$. Anhembi, 1999 e 2000.

\begin{tabular}{|c|c|c|c|c|}
\hline FV & GL & QM & $\mathrm{CV}(\%)$ & Média \\
\hline \multicolumn{5}{|c|}{ Altura da planta $(\mathrm{cm})$} \\
\hline Local & 1 & $150722,93^{* *}$ & 8,79 & 155,80 \\
\hline Bloco (Local) & 4 & $360,20^{\text {ns }}$ & & \\
\hline Progênies & 99 & $809,07 * *$ & & \\
\hline Progênies $\mathrm{x}$ ano & 99 & $239,92^{\mathrm{ns}}$ & & \\
\hline Resíduo médio & 396 & 187,55 & & \\
\hline \multicolumn{5}{|c|}{ Altura da espiga $(\mathrm{cm})$} \\
\hline Local & 1 & $47328,03^{* *}$ & 12,92 & 82,50 \\
\hline Bloco (Local) & 4 & $300,80^{*}$ & & \\
\hline Progênies & 99 & $393,70^{* *}$ & & \\
\hline Progênies $\mathrm{x}$ ano & 99 & $151,87^{*}$ & & \\
\hline Resíduo médio & 396 & 113,64 & & \\
\hline \multicolumn{5}{|c|}{ Posição da espiga na planta } \\
\hline Local & 1 & $0,00662^{\mathrm{ns}}$ & 9,21 & 0,529 \\
\hline Bloco (Local) & 4 & $0,00613^{*}$ & & \\
\hline Progênies & 99 & $0,00767^{* *}$ & & \\
\hline Progênies $\mathrm{x}$ ano & 99 & $0,00293^{\text {ns }}$ & & \\
\hline Resíduo médio & 396 & 0,00237 & & \\
\hline \multicolumn{5}{|l|}{ Estande } \\
\hline Local & 1 & $6,5481^{15}$ & 28,75 & 14,35 \\
\hline Bloco (Local) & 4 & $48,6031^{*}$ & & \\
\hline Progênies & 99 & $53,1861^{*}$ & & \\
\hline Progênies $\mathrm{x}$ ano & 99 & $21,8498^{*}$ & & \\
\hline Resíduo médio & 393 & 17,0083 & & \\
\hline \multicolumn{5}{|c|}{ Peso de espigas (g/planta) } \\
\hline Local & 1 & $7910,80^{* *}$ & 23,05 & 57,22 \\
\hline Bloco (Local) & 4 & $404,42^{\text {ns }}$ & & \\
\hline Progênies & 99 & $941,33^{* *}$ & & \\
\hline Progênies $\mathrm{x}$ ano & 99 & $212,47^{\text {ns }}$ & & \\
\hline Resíduo médio & 392 & 173,96 & & \\
\hline \multicolumn{5}{|c|}{ Número de espigas da parcela } \\
\hline Local & 1 & $750,033^{* *}$ & 24,11 & 15,05 \\
\hline Bloco (Local) & 4 & $22,343^{\text {ns }}$ & & \\
\hline Progênies & 99 & $67,773 * *$ & & \\
\hline Progênies $\mathrm{x}$ ano & 99 & $15,247^{\text {as }}$ & & \\
\hline Resíduo médio & 395 & 13,170 & & \\
\hline \multicolumn{5}{|c|}{ Número de espiga / planta } \\
\hline Local & 1 & $2,45883^{* *}$ & 23,99 & 1,076 \\
\hline Bloco (Local) & 4 & $0,16875^{\text {ns }}$ & & \\
\hline Progênies & 99 & $0,12114^{* *}$ & & \\
\hline Progênies $\mathrm{x}$ ano & 99 & $0,07436^{\mathrm{ns}}$ & & \\
\hline Resíduo médio & 392 & 0,06659 & & \\
\hline
\end{tabular}

${ }^{*},{ }^{* *} \mathrm{P} \leq 0,05$ e $\mathrm{P} \leq 0,01$, respectivamente. 
Tabela 45. Análise de variância conjunta da população de milho Piranão VF1B no segundo ciclo de seleção do método Seleção $S_{1}$. Anhembi, 1999 e 2000.

\begin{tabular}{|c|c|c|c|c|}
\hline FV & GL & QM & CV(\%) & Média \\
\hline \multicolumn{5}{|c|}{ Altura da planta $(\mathrm{cm})$} \\
\hline Local & 1 & $69101,76^{* *}$ & 7,25 & 183,42 \\
\hline Bloco (Local) & 4 & $294,53^{\text {ns }}$ & & \\
\hline Progênies & 31 & $1259,66^{* *}$ & & \\
\hline Progênies $\mathrm{x}$ ano & 31 & $333,00 * *$ & & \\
\hline Resíduo médio & 122 & 176,10 & & \\
\hline \multicolumn{5}{|c|}{ Altura da espiga (cm) } \\
\hline Local & 1 & $17099,49^{* *}$ & 11,33 & 108,52 \\
\hline Bloco (Local) & 4 & $79,54^{\mathrm{ns}}$ & & \\
\hline Progênies & 31 & $912,31^{* *}$ & & \\
\hline Progênies $x$ ano & 31 & $291,09 * *$ & & \\
\hline Resíduo médio & 122 & 151,25 & & \\
\hline \multicolumn{5}{|c|}{ Posicão da espiga na planta } \\
\hline Local & 1 & $0,01686^{* *}$ & 8,02 & 0,591 \\
\hline Bloco (Local) & 4 & $0,00034^{\text {ns }}$ & & \\
\hline Progênies & 31 & $0,00666^{* *}$ & & \\
\hline Progênies $x$ ano & 31 & $0,00296^{\text {ns }}$ & & \\
\hline Resíduo médio & 122 & 0,00224 & & \\
\hline \multicolumn{5}{|l|}{ Estande } \\
\hline Local & 1 & $68,0822^{* *}$ & 18,08 & 15,42 \\
\hline Bloco (Local) & 4 & $5,1635^{\mathrm{ns}}$ & & \\
\hline Progênies & 31 & $53,8296 * *$ & & \\
\hline Progênies $\mathrm{x}$ ano & 31 & $26,7016^{* *}$ & & \\
\hline Resíduo médio & 122 & 7,7925 & & \\
\hline \multicolumn{5}{|c|}{ Peso de espigas (g/planta) } \\
\hline Local & 1 & $4809,62^{* *}$ & 22,02 & 63,04 \\
\hline Bloco (Local) & 4 & $774,87^{* *}$ & & \\
\hline Progênies & 31 & $493,91^{* *}$ & & \\
\hline Progênies $x$ ano & 31 & $342,31^{*}$ & & \\
\hline Resíduo médio & 120 & 192,71 & & \\
\hline \multicolumn{5}{|c|}{ Número de espigas da parcela } \\
\hline Local & 1 & $299,922 * *$ & 21,17 & 15,96 \\
\hline Bloco (Local) & 4 & $6,888^{\mathrm{ns}}$ & & \\
\hline Progênies & 31 & $75,365^{* *}$ & & \\
\hline Progênies $\mathrm{x}$ ano & 31 & $22,973 * *$ & & \\
\hline Resíduo médio & 120 & 11,419 & & \\
\hline \multicolumn{5}{|c|}{ Número de espigas / planta } \\
\hline Local & 1 & $0,10361^{\mathrm{ns}}$ & 21,56 & 1,057 \\
\hline Bloco (Local) & 4 & $0,07827^{\text {as }}$ & & \\
\hline Progênies & 31 & $0,14297^{* *}$ & & \\
\hline Progênies $\mathrm{x}$ ano & 31 & $0,06453^{\text {ns }}$ & & \\
\hline Resíduo médio & 120 & 0,05194 & & \\
\hline
\end{tabular}


Tabela 46. Análise de variância conjunta da população de milho Piranão VD2B no segundo ciclo de seleção do método Seleção $S_{1}$. Anhembi, 1999 e 2000.

\begin{tabular}{|c|c|c|c|c|}
\hline FV & GL & $\mathbf{Q M}$ & $\mathrm{CV}(\%)$ & Média \\
\hline \multicolumn{5}{|c|}{ Altura da planta (cm) } \\
\hline Local & 1 & $109749,86^{* *}$ & 8,69 & 146,94 \\
\hline Bloco (Local) & 4 & $2219,22^{* *}$ & & \\
\hline Progênies & 83 & $1371,23^{* *}$ & & \\
\hline Progênies $x$ ano & 83 & $196,37^{\text {ns }}$ & & \\
\hline Resíduo médio & 332 & 163,05 & & \\
\hline \multicolumn{5}{|c|}{ Altura da espiga (cm) } \\
\hline Local & 1 & $31067,16^{* *}$ & 13,52 & 81,52 \\
\hline Bloco (Local) & 4 & $1189,99 * *$ & & \\
\hline Progênies & 83 & $485,81^{* *}$ & & \\
\hline Progênies $\mathrm{x}$ ano & 83 & $138,69^{\text {ns }}$ & & \\
\hline Resíduo médio & 332 & 121,47 & & \\
\hline \multicolumn{5}{|c|}{ Posição da espiga na planta } \\
\hline Local & 1 & $0,00114^{\text {ns }}$ & 8,86 & 0,554 \\
\hline Bloco (Local) & 4 & $0,00386^{\mathrm{ns}}$ & & \\
\hline Progênies & 83 & $0,00582 * *$ & & \\
\hline Progênies $\mathrm{x}$ ano & 83 & $0,00329 *$ & & \\
\hline Residuo médio & 332 & 0,00241 & & \\
\hline \multicolumn{5}{|l|}{ Estande } \\
\hline Local & 1 & $17,1136^{\mathrm{ns}}$ & 20,85 & 14,65 \\
\hline Bloco (Local) & 4 & $55,9028 * *$ & & \\
\hline Progênies & 83 & $67,7474 * *$ & & \\
\hline Progênies $x$ ano & 83 & $13,4166^{*}$ & & \\
\hline Resíduo médio & 331 & 9,3285 & & \\
\hline \multicolumn{5}{|c|}{ Peso de espigas (g/planta) } \\
\hline Local & 1 & $67972,10^{* *}$ & 23,46 & 50,65 \\
\hline Bloco (Local) & 4 & $193,44^{\text {ns }}$ & & \\
\hline Progênies & 83 & $714,74^{* *}$ & & \\
\hline Progênies $x$ ano & 83 & $334,74 * *$ & & \\
\hline Resíduo médio & 329 & 141,23 & & \\
\hline \multicolumn{5}{|c|}{ Número de espigas da parcela } \\
\hline Local & 1 & $9,8689^{\mathrm{ns}}$ & 28,13 & 14,07 \\
\hline Bloco (Local) & 4 & $95,7095^{* *}$ & & \\
\hline Progênies & 83 & $85,7005^{* *}$ & & \\
\hline Progênies $\mathrm{x}$ ano & 83 & $15,9261^{\mathrm{ns}}$ & & \\
\hline Resíduo médio & 326 & 15,6738 & & \\
\hline \multicolumn{5}{|c|}{ Número de espigas / planta } \\
\hline Local & 1 & $0,60629^{* *}$ & 23,59 & 0,977 \\
\hline Bloco (Local) & 4 & $0,04282^{\text {ns }}$ & & \\
\hline Progênies & 83 & $0,18935^{* *}$ & & \\
\hline Progênies $\mathrm{x}$ ano & 83 & $0,05807^{\text {ns }}$ & & \\
\hline Resíduo médio & 326 & 0,05312 & & \\
\hline
\end{tabular}

${ }^{*},{ }^{* *} \mathrm{P} \leq 0,05$ e $\mathrm{P} \leq 0,01$, respectivamente. 
Tabela 47. Análise de variância conjunta da população de milho ESALQ-PR1 no segundo ciclo de seleção do método Seleção S 1 . Anhembi, 1999 e 2000.

\begin{tabular}{|c|c|c|c|c|}
\hline FV & GL & QM & CV(\%) & Média \\
\hline \multicolumn{5}{|c|}{ Altura da Planta (cm) } \\
\hline Local & 1 & $54114,17^{* *}$ & 9,32 & 176,36 \\
\hline Bloco (Local) & 4 & $1150,14^{* *}$ & & \\
\hline Progênies & 64 & $876,71^{* *}$ & & \\
\hline Progênies $\mathrm{x}$ ano & 63 & $327,08^{\text {ns }}$ & & \\
\hline Resíduo médio & 250 & 270,14 & & \\
\hline \multicolumn{5}{|c|}{ Altura da Espiga (cm) } \\
\hline Local & 1 & $5538,19 * *$ & 11,59 & 104,89 \\
\hline Bloco (Local) & 4 & $576,46^{* *}$ & & \\
\hline Progênies & 64 & $618,58^{* *}$ & & \\
\hline Progênies $\mathrm{x}$ ano & 63 & $175,80^{\text {ns }}$ & & \\
\hline Resíduo médio & 250 & 147,74 & & \\
\hline \multicolumn{5}{|c|}{ Posição da espiga na planta } \\
\hline Local & 1 & $0,13572^{* *}$ & 7,35 & 0,596 \\
\hline Bloco (Local) & 4 & $0,00257^{\mathrm{ns}}$ & & \\
\hline Progênies & 64 & $0,00643 * *$ & & \\
\hline Progênies $\mathrm{x}$ ano & 63 & $0,00368^{* *}$ & & \\
\hline Resíduo médio & 250 & 0,00192 & & \\
\hline \multicolumn{5}{|l|}{ Estande } \\
\hline Local & 1 & $507,9760^{* *}$ & 16,70 & 15,00 \\
\hline Bloco (Local) & 4 & $10,3378^{\text {ns }}$ & & \\
\hline Progênies & 64 & $43,0304 * *$ & & \\
\hline Progênies $\mathrm{x}$ ano & 63 & $22,8095 * *$ & & \\
\hline Resíduo médio & 247 & 6,2739 & & \\
\hline \multicolumn{5}{|c|}{ Peso de espigas (g/planta) } \\
\hline Local & 1 & $10672,87^{* *}$ & 20,21 & 60,78 \\
\hline Bloco (Local) & 4 & $77,35^{\text {ns }}$ & & \\
\hline Progênies & 64 & $1939,97^{* *}$ & & \\
\hline Progênies $\mathrm{x}$ ano & 63 & $471,58^{* *}$ & & \\
\hline Resíduo médio & 244 & 150,95 & & \\
\hline \multicolumn{5}{|c|}{ Número de espigas } \\
\hline Local & 1 & $306,749 * *$ & 18,98 & 16,69 \\
\hline Bloco (Local) & 4 & $0,984^{\text {ns }}$ & & \\
\hline Progênies & 64 & $167,573^{* *}$ & & \\
\hline Progênies $\mathrm{x}$ ano & 63 & $33,228 * *$ & & \\
\hline Resíduo médio & 246 & 10,028 & & \\
\hline \multicolumn{5}{|c|}{ Número de espigas / planta } \\
\hline Local & 1 & $0,07989^{\text {ns }}$ & 20,76 & 1,113 \\
\hline Bloco (Local) & 4 & $0,04113^{\mathrm{ns}}$ & & \\
\hline Progênies & 64 & $0,31201^{* *}$ & & \\
\hline Progênies $x$ ano & 63 & $0,07559 *$ & & \\
\hline Resíduo médio & 243 & 0,05336 & & \\
\hline
\end{tabular}

${ }^{*}{ }^{* *} \mathrm{P} \leq 0,05$ e $\mathrm{P} \leq 0,01$, respectivamente. 
FIGURAS 


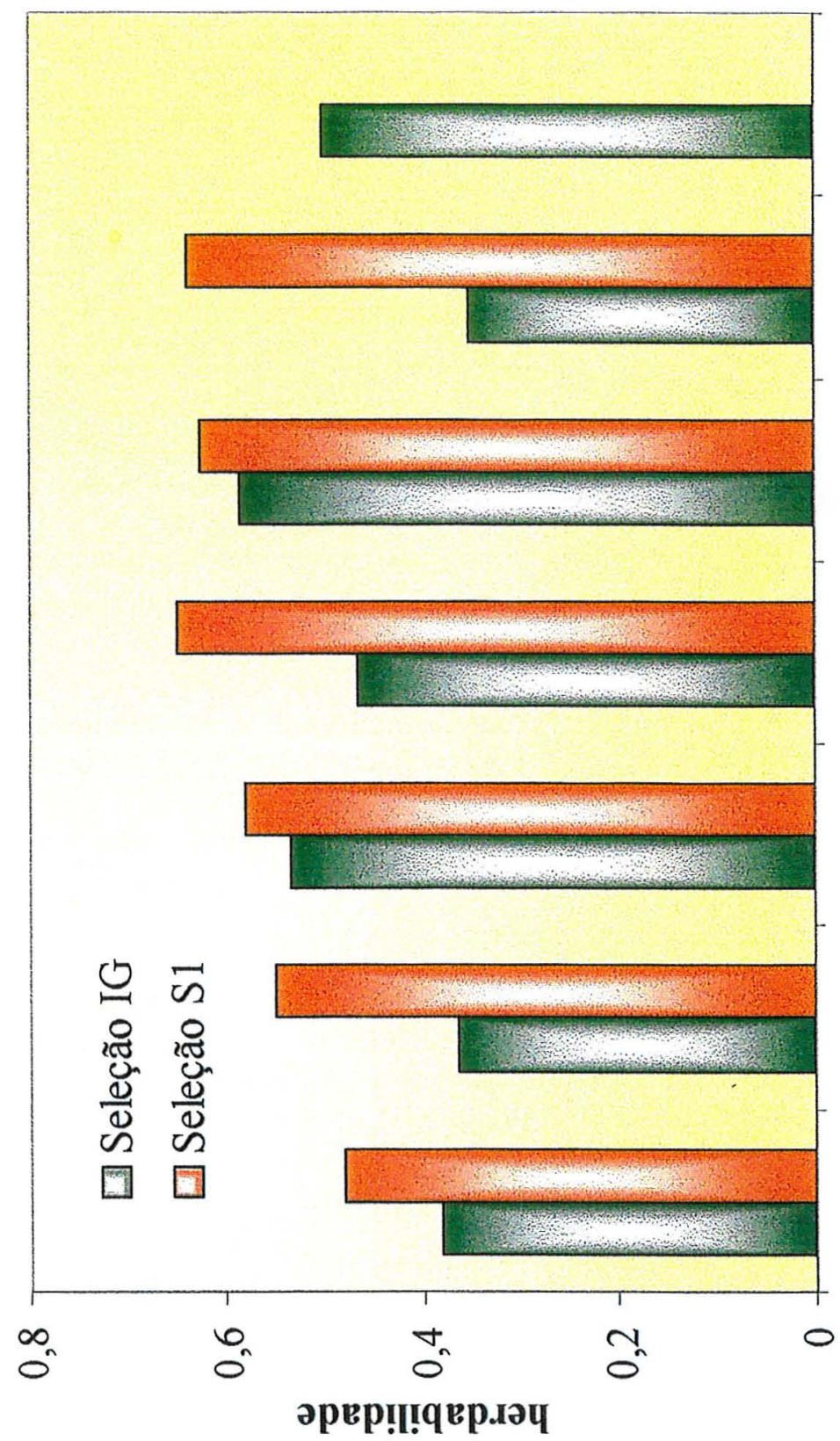

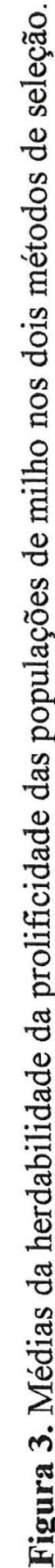




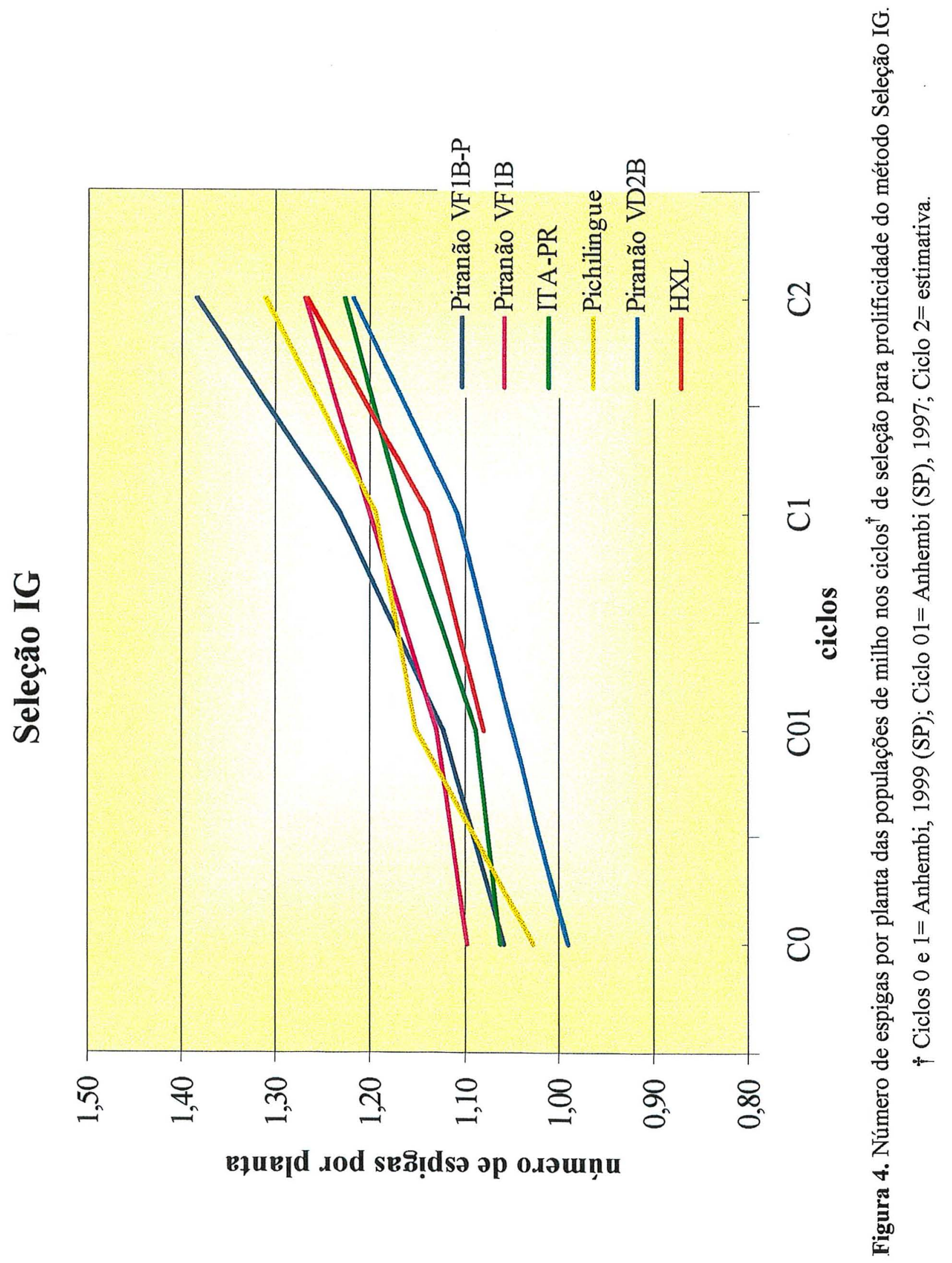




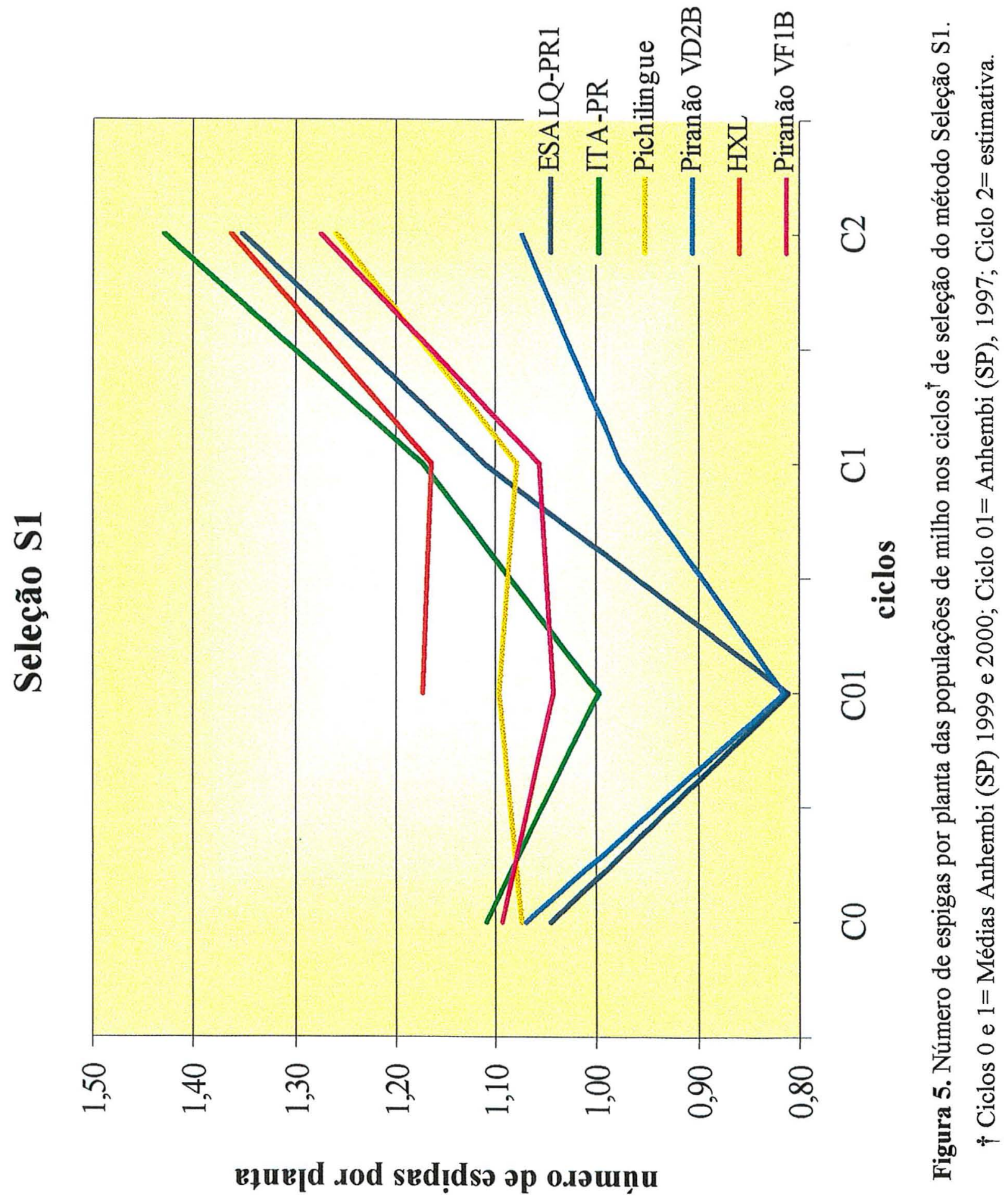




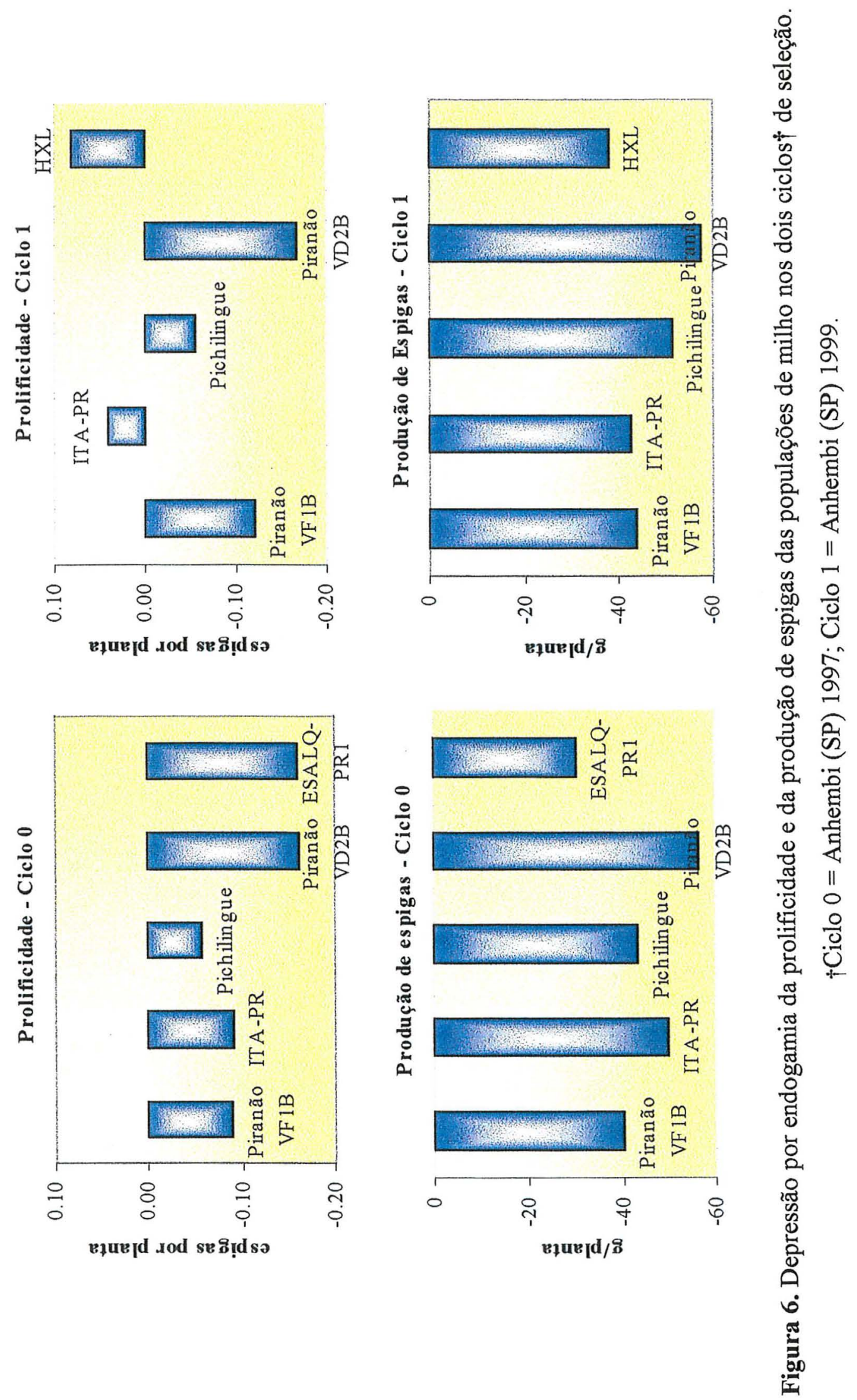


Média do comprimento das segundas espigas

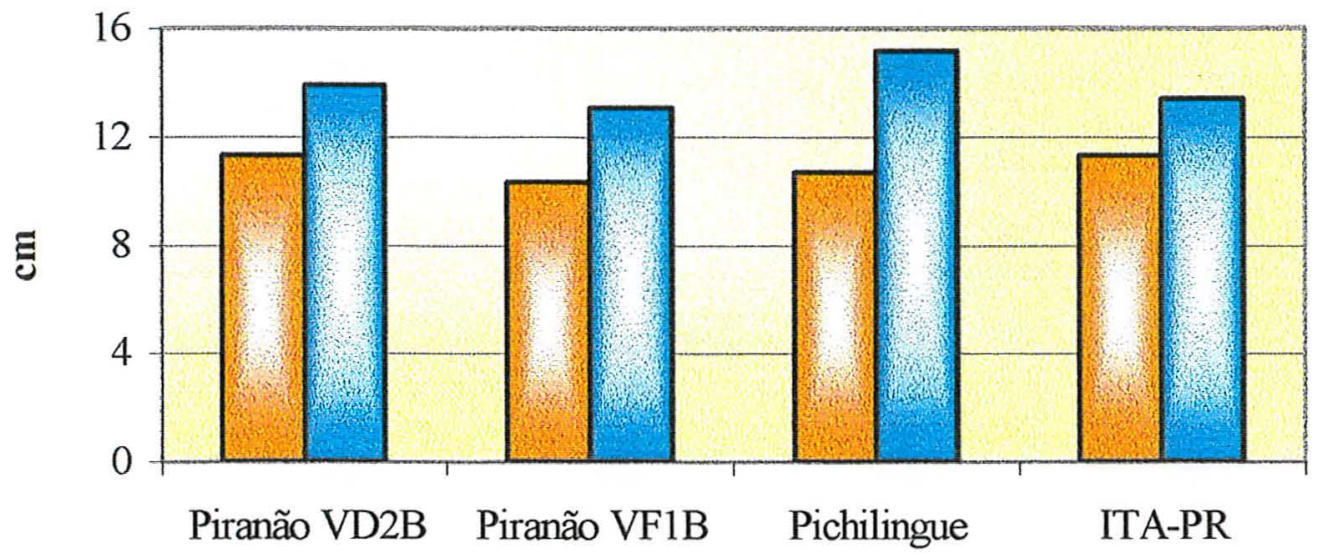

Média do diâmetro das segundas espigas

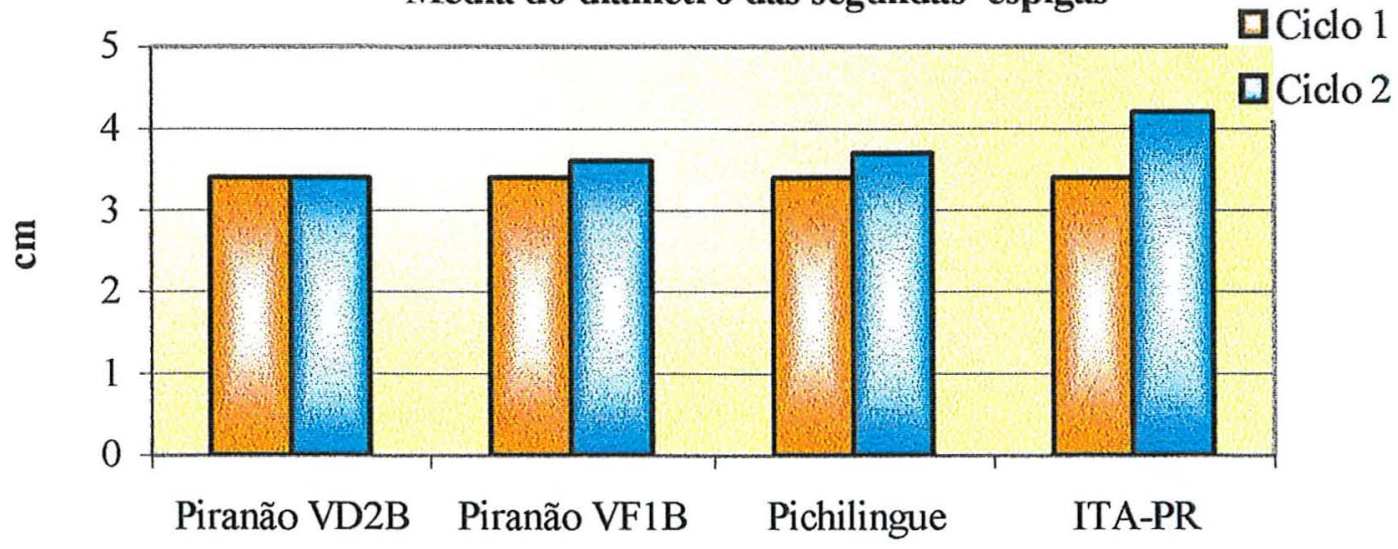

Média do peso de grãos das segundas espigas

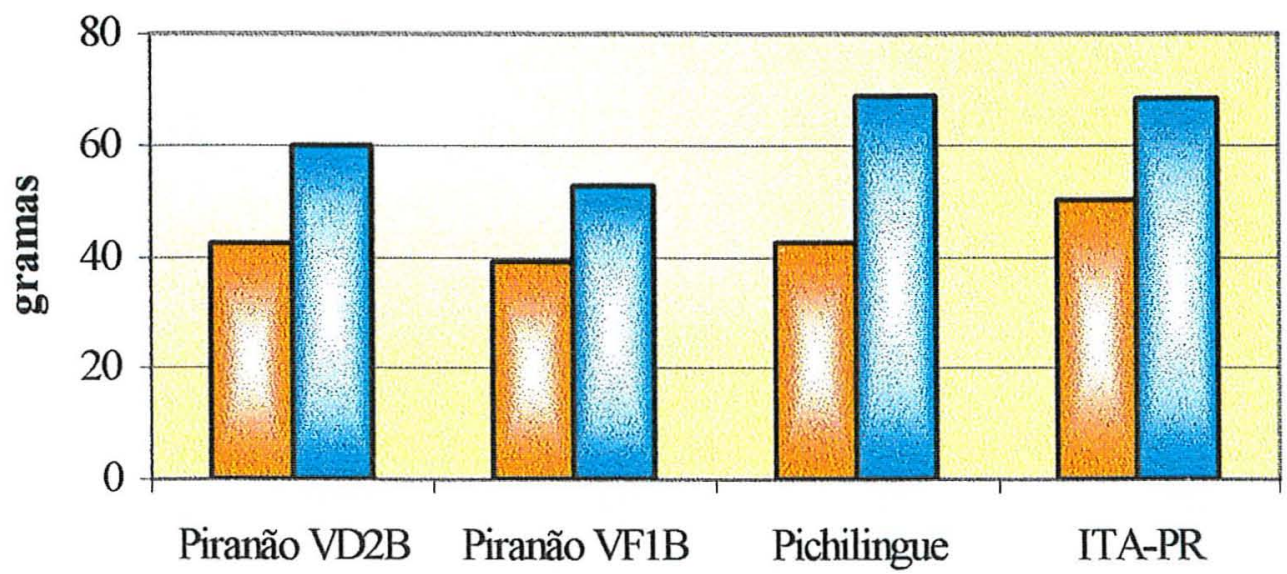

Figura 7. Médias do comprimento, diâmetro e peso de grãos das segundas espigas das populações de milho nos dois ciclos de seleção para prolificidade no método Seleção $\mathrm{S}_{1}$. 


\section{REFERÊNICAS BIBLIOGRÁFICAS}

AGRAMA, H.A.S. Sequential path analysis of grain yield and its components in maize. Plant Breeding, v.115, n.5, p.343-346, 1996.

ANDERSON, E.L; KAMPRATH, E.J.; MOLL, R.H. Nitrogen fertility effects on accumulation, remobilization, and partitioning of $\mathrm{N}$ and dry matter in corn genotypes differing in prolificacy. Crop Science, v.76, p. 397-404, 1984.

BIASUTTI; C.A.; PEIRETTI, D.A. Asociación de caracteres morfológicos en poplaciones de maíz (Zea mays L.) en condiciones de estrés y no estrés hídrico. Agroscientia, v.9, p.59-64, 1992.

BLUM, A. Plant breeding for stress environments. Boca Raton: CRC Press, 1988.

BOLAÑOS, J.; EDMEADES, G.O. Eight cycles of selection for drought tolerance in lowland tropical maize. I. Responses in grain, yield, biomass and radiation utilization. Field Crops Research, v.31, p.233-252, 1993.

BOLAÑOS, J.; EDMEADES, G.O. The importance of the anthesis-silking interval in breeding for drought tolerance in tropical maize. Field Crops Research, v. 48, p.65-80, 1996.

BROTSLAW, D.J.; DARRAH, L.L.; ZUBER, M.S.; KRAUSE, G.F. Effect of prolificacy on grain yield and root and stalk strength in maize. Crop Science, v.28, p.750-755, 1988. 
BROWN, W.L. Physical characteristics of corn of the future. In: ANNUAL HYBRID CORN INDUSTRIAL RESEARCH CONFERENCE, 20., Chicago, 1965. Proceedings. Chicago: American Seed Trade Association, 1965. p.7-16.

BUREN, L.L.; MOCK, J.J.; ANDERSON, I.C. Morphological and physiological traits in maize associated with tolerance to high plant density. Crop Science, v.14, p.426429,1974 .

CAMBERATO, J.J.; KAMPRATH.E.J.; MOLL, R.H.; JACKSON, W.A. Apical and subapical earshoot development of prolific maize hybrids (Zea mays L.): the role of nitrogen. Maydica, v.34, p.309-317, 1989.

CASNOFF, D.M. Nitrogen: its effect on the expression of prolificacy and its utilization by prolific and non-prolific genotypes of maize (Zea mays L.). Dissertation Abstracts International,v.44, p.2621b-2622b, 1984.

CASTRO, E.M. Competição entre populações de milho normais e braquíticas. Piracicaba, 1983. 156p. Tese (Doutorado) - Escola Superior de Agricultura "Luiz de Queiroz", Universidade de São Paulo.

CHANH TA, T.; ROESKE, C.A.; EAGLESHAM, A.R.J. Changes in maize-stalk proteins during ear development. Physiologia Plantarum; v.87, p.21-24, 1993.

CLINE, M.G. Concepts and terminology of apical dominance. American Journal of Botany, v.84, p.1064-1069, 1997.

COLLINS, W.K.; RUSSELL, W.A.; EBERHART, S.A. Performance of two ear type of corn belt maize. Crop Science, v.40, p.35-50, 1965.

COMPTON, W.A.; MUMM, R.F.; MATHENA, B. Progress from adaptive mass selection in incompletely adapted maize populations. Crop Science, v.19, p.531$533,1979$. 
COORS, J.G.; MARDONES, M.C. Twelve cycles of mass selection for prolificacy in maize. I. Direct and correlated responses. Crop Science, v.29, p.262-266, 1989.

COX, W. Whole-plant physiological and yield responses of maize to plant density. Agronomy Journal, v.88, p.489-496, 1996.

CROW, J.F.; KIMURA, M. An introduction to population genetics. New York: Harper and Row, 1970. 571p.

DAMPTEY, H.B. The effect of water deficit, hormones and mineral nutrition on the growth of axillary inflorescence in Zea mays L. Ghana Journal of Science, v. 2228, p.17-28, 1982. Resumo em CAB Abstracts on CD-ROM, 1994-96/

DURIEUX, R.P. Root activity and nutrient uptake and accumulation in prolific and nonprolific corn. Dissertation Abstracts International.-B, Sciences and Engineering, v.51, n.4, p.1557-B, 1990.

DURIEUX, R.P.; KAMPRATH, E.J.; MOLL, R.H. Yield contribution of apical and subapical ears in prolific and nonprolific corn. Agronomy Journal, v.85, p.606$610,1993$.

DUVICK, D.N. Continuous backcrossing to transfer prolificacy to a single-eared inbred line of maize. Crop Science, v.14, p.69-71, 1974.

FALCONER, D.S.; MACKAY, T.F.C. Introduction to quantitative genetics. Essex: Longman, 1996. 464p.

FISCHER, K.S.; EDMEADES, G.O.; JOHNSON, E.C. Selection for the improvement of maize yield under moisture-deficits. Field Crops Research, v.22, p.227-243, 1989.

GAMA, E.E.G.; VIANNA, R.T.; NASPOLINI FILHO, V.; MAGNAVACA, R. Efeito depressivo da endogamia em gerações avançadas de quatro tipos genéticos de híbridos de milho. Pesquisa Agropecuária Brasileira, v.20, p.1293-1300, 1985. 
GARDNER, C.O.; HARVEY, P.H.; COMSTOCK, R.E.; ROBINSON, H.F. Dominance of genes controlling quantitative characters in maize. Agronomy Journal, v., p. 186$191,1953$.

GOOD, R.L.; HALLAUER, A.R. Inbreeding depression in maize by selfing and fullsibbing. Crop Science, v.17, p.935-940, 1977.

GOULAS, C.K.; LONNQUIST, J.H. Combined half-sib and S1 family selection in a maize population. Crop Science, v.16, p.461-464, 1976.

GUEI, R.G.; WASSOM, C.E. Inheritance of some drought adaptive traits in maize: I. Interrelationships between yield, flowering, and ears per plant. Maydica, v.37, p.157-164, 1992.

HALLAUER, A. Heritability of prolificacy in maize. The Journal of Heredity, v.65, p.163-168, 1974.

HALlAUER, A.R.; MIRANDA FILHO, J.B. Quantitative Genetics in Maize Breeding. Ames: Iowa State University Press, 1988. 468p.

HALLAUER, A.R.; TROYER, A.F. Prolific corn hybrids and minimizing risk of stress. In: ANNUAL HYBRID CORN INDUSTRIAL RESEARCH CONFERENCE, 27., Chicago, 1972. Proceedings. Chicago: American Seed Trade Association, 1972. p.140-158.

HARRIS, R.E.; MOLL, R.H.; STUBER, C.W. Control and inheritance of prolificacy in maize. Crop Science, v.16, p.843-851,1976.

JACOBS. B.C.; PEARSON, C.J. Potential yield of maize, determined by rates of growth and development of ears. Field Crops Research, v.27, p.281-298, 1991.

KAMPRATH, E.J.; MOLL, R.H.; RODRIGUEZ, N. Effects of nitrogen fertilization and recurrent selection on performance of hybrid populations of corn. Agronomy Journal, v.74, p.955-958, 1982. 
KAMPRATH, E.J; MOLL, R.H.; RODRIGUEZ, N. Effects of nitrogen fertilization and recurrent selection on performance of hybrid populations of corn. Crop Science, v.74, 1982.

KASSOUF, A.L.; MRANDA FILHO, J.B. Variabilidade e endogamia na população de milho ESALQ-PG ${ }^{1}$. In: CONGRESSO NACIONAL DE MILHO E SORGO, 15., Maceió, 1984. Anais. Brasília: EMBRAPA-CNPMS, 1986. p.119-131.

LAFITTE, H.R.; EDMEADES, G.O. Stress tolerance in tropical maize is linked to constitutive changes in ear growth characteristics. Crop Science, v.35, p.820-826, 1995.

LAIBLE, C.A.; DIRKS, V.A. Genetic variance and selective value of ear neumber in corn (Zea mays L.). Crop Science, v.8, p.540-542, 1968.

LAMKEY, K.R.; HALLAUER, A.R. Comparison of maize populations improved by recurrent selection. Maydica, v.29, p.357-374, 1984.

LEJEUNE, P.; BERNIER, G. Effect of environment on the early steps o ear initiation in maize (Zea mays L.). Plant Cell and Environment, v. 19, p.217-224, 1996.

LI, C.C. Population genetics. Pacific Grove (CA): Boxwood Press, 1976.

LI, C.J.; GUEVARA, E.; HERRERA, J.; BANGERTH, F. Effect of apex excision and replacement by 1 -naphthylacetic acid on cytokinin concentration and apical dominance in pea plants. Physiologia Plantarum, v.94, p.465-469, 1995.

LONNQUIST, J.H. Mass selection for prolificacy in maize. Der Züchter, v.37, p.185$188,1967$.

LORDELO, J.A.C. Parâmetros genéticos das populações de milho Piranão VD2 e Piranão VF1. Piracicaba, 1982. 63p. Dissertação (Mestrado ) - Escola Superior de Agricultura “Luiz de Queiroz”, Universidade de São Paulo. 
MAITA, R.; COORS, J.; AVILA, L.G.; CESPEDES, P.LM. Twenty cycles of biparental mass selection for prolificacy in the maize population Golden Glow. Direct and indirect responses. In: REUNION LATINOAMERICANA, 3; REUNION DE LA ZONA ANDINA DE INVESTIGADORES EN MAIZ, 16., Cochabamba, Bolívia, 1995. Memorias. Cochabamba: CIFP, 1995a. p.1031-1053.

MAITA, R.; COORS, J.; AVILA, L.G.; CESPEDES, P.LM. Twenty cycles of biparental mass selection for prolificacy in the maize population Golden Glow. Analysis of phenotypic stability. In: REUNION LATINOAMERICANA, 3.; REUNION DE LA ZONA ANDINA DE INVESTIGADORES EN MAIZ, 16., Cochabamba, Bolívia, 1995. Memorias. Cochabamba: CIFP, 1995b. p.1055-1070.

MAITA, R.; COORS, J.G. Twenty cycles of biparental mass selection for prolificacy in the open-pollinated maize population Golden Glow. Crop Science, v.36, p.1527$1532,1996$.

MANI, V.P.; DUBE, S.D. Genetics of prolificacy in maize. Annals of Agricultural Research, v.18, p.194-199, 1997.

MARECK, J.H.; GARDNER, C.O. Responses to mass selection and stability of resulting populations. Crop Science, v.19, p.779-783, 1979.

MARIANI, G.; DESIDERIO, E. Grain yield and prolificacy in maize. 2. A diallel analysis of eight inbreds from the O.P. variety Nostrano Dell'Isola at two densities. Maydica, v.20, p.95-110, 1975.

MIRANDA FILHO, J.B.; VENCOVSKY, R. Considerações sobre o tamanho efetivo de populações para a preservação de germoplasmas. Relatório Científico do Instituto de Genética (ESALQ/USP),v.12, p.122-130, 1978.

MIRANDA FILHO, J.B.; VENCOVSKY, R. The partial circulant diallel cross at the interpopulation level. Genetics and Molecular Biology, v.22, p.249-255, 1999. 
MOLL, R.H.; KAMPRATH, E.J. Effects of population density upon agronomic traits associated with genetic increases in yield of Zea mays L. Agronomy Journal, v.69, p.81-84, 1977.

MOLL, R.H.; MOTTO, M.; TOLEDO, J.F. Prediction and inheritance of prolific expression in maize hybrids. Maydica, v.26, p.273-285, 1981.

MORELLO; C.L.; SANTOS, M.X.; RAMALHO, M.A.P.; OLIVEIRA, A.C. Efeito da densidade de plantas na seleção massal para prolificidade em milho (Zea mays L.). Ciência e Prática, v.18, p.357-364, 1994.

MOTTO, M.; MOLL, R.H. Prolificacy in maize: a review. Maydica, v.28, p.53-76, 1983.

NASS, L.L. Variabilidade genética de populações semi-exóticas de milho (Zea mays L.). Piracicaba, 1992. 136p. Tese (Doutorado) - Escola Superior de Agricultura 'Luiz de Queiroz", Universidade de São Paulo.

NASS, L.L.; MIRANDA FILHO, J.B. Inbreeding depression rates of semi-exotic maize (Zea mays L.) populations. Brazilian Journal of Genetics, v.18, p.585-592, 1995.

OTEGUI, M.E. Prolificacy and grain yield components in modern Argentinian maize hybrids. Maydica, v.40, n.4, p.371-376, 1995.

PACKER, D. Variabilidade genética e endogamia em quatro populações de milho (Zea mays L.). Piracicaba, 1998. 102p. Tese (Doutorado) - Escola Superior de Agricultura "Luiz de Queiroz", Universidade de São Paulo.

PAN, W.L.; CAMBERATO, J.J.; JACKSON, W.A.; MOLL, R.H. Utilization of previously accumulated and concurrently absorbed nitrogen during reproductive growth in maize. Plant Physiology, v.82, p.247-253, 1986. 
PAN, W.L.; CAMBERATO, J.J.; MOLL, R.H. et al. Altering source-sink relationships in prolific maize hybrids: consequences for nitrogen uptake and remobilization. Crop Science, v.35, p.836-845, 1995.

PATERNIANI, E. Evolução do milho e implicações no melhoramento. In: COLÓQUIO SOBRE CITOGENÉTICA E EVOLUÇÃO DE PLANTAS, 1, Piracicaba, 1984. Tópicos de Citogenética e Evolução de Plantas. Piracicaba: ESALQ/USP, 1984.

PATERNIANI, E. Influence of tassel size on ear placement in maize (Zea mays L.) Maydica, v.26, p.85-91, 1981.

PATERNIANI, E. Phenotypic recurrent selection for prolificacy in maize. Maydica, v.23, p.29-34, 1978.

PATERNIANI, E. Resultados de três ciclos de seleção para prolificidade em duas populações de milho. In: REUNIÃO BRASILEIRA DE MILHO E SORGO, 1980. Resumos. 1980a. p.15.

PATERNIANI, E. Seleção massal com controle biparental para a prolificidade em milho. Relatório Científico do Instituto de Genética (ESALQ/USP), v.14, p.69$76,1980 \mathrm{~b}$.

PATERNIANI, E.; VENCOVSKY, R. Reciprocal recurrent selection based on half-sib progenies and prolific plants in maize (Zea mays L.). Maydica, v.22, p.141-152, 1978.

PHILLIPS, I.D.J. Apical dominance. Annual Reveal of Plant Physiology, v.26, p.341$367,1975$.

PINTHUS, M.J.; BELCHER, A.R. Maize topmost axillary shoot interference with lower ear development in vitro. Crop Science, v.34, p.458-461, 1994.

PRIOR, C.L.; RUSSEL, W.A. Yield performance of nonprolific and prolific maize hybrids at six plant densities. Crop Science, v.15, p.482-485, 1975. 
RISTAKOVIC, D.; TRIFONOVIC, V. Heritability of ear number in prolific maize hybrids (Zea mays L.). MEETING OF THE MAIZE AND SORGHUM SECTION OF EUCARPIA, 10., Varna, Bulgária, 1979. Proceedings. 1983. p.296-310. / Resumo em CAB Abstracts on CD-ROM, 1983-84/

ROBINSON, H.F.; COMSTOCK, R.E; HARVEY, P.H. Genotypic and phenotypic correlations in corn and their implications in selection. Agronomy Journal, v.43, p.282-287, 1951.

RUSSEL, W.A. Testcrosses of one and two ear types of corn belt maize inbreds. I. Performance at four plant stand densities. Crop Science, v.8, p.244-247, 1968.

SASS, J.E.; LOEFFEL, F.A. Development of auxiliary buds in maize in relation to barrenness. Agronomy Journal, v.51, p.484-486, 1959.

SEGOVIA, F.F.S. Avaliação da seleção massal em ambos os sexos para prolificidade em milho (Zea mays L.). Piracicaba, 1983. 91p. Dissertação (Mestrado) - Escola Superior de Agricultura "Luiz de Queiroz", Universidade de São Paulo.

SING, D.F.; MOLL, R.H.; HANSON, W.D. Inbreeding in two populations of Zea mays L. Crop Science, v.7, p.631-636, 1967.

SINGH, M.; KHEHRA, A.S.; DHILLON, B.S. Direct and correlated response to recurrent full-sib selection for prolificacy in maize. Crop Science, v.26, p.275-278, 1986.

SOARES FILHO, W.S. Características fenotípicas e genéticas das populações de milho (Zea mays L.) braquítico Piranão VD2B e Piranão VF1B. Piracicaba, 1987. 185p. Tese (Doutorado) - Escola Superior de Agricultura "Luiz de Queiroz", Universidade de São Paulo. 
SORRELLS, M.E.; HARRIS, R.E.; LONNQUIST, J.H. Response of prolific and nonprolific maize to growth regulating chemicals. Crop Science, v.18, p.783787,1978 .

SORRELLS, M.E.; LONNQUIST, J.H.; HARRIS, R.E. Inheritance of prolifcicacy in maize. Crop Science, v.19, p.301-306, 1979.

SOUZA JÚNIOR, C.L. Componentes da variância genética e suas implicações no melhoramento vegetal. Piracicaba: FEALQ, 1989. 134p.

SOUZA JÚNIOR, C.L.; GERALDI; I.O.; ZINSLY, J.R. Influence of tassel size on the expression of prolificacy in maize (Zea mays L.). Maydica, v.30, p.321-328, 1985.

SPRAGUE, G.F.; BRIMHALL, B. Relative effectiveness of two systems for selection for oil content of the corn kernel. Agronomy Journal, v.42, p.83-88, 1950.

STUBER, C.W.; MOLL, R.H.; HANSON, W.D. Genetic variances and interrelationships of six traits in a hybrid population of Zea mays L. Crop Science, v.6, p.455-458, 1966.

SUBANDI. Ten cycles of selection for prolificacy in a composite variety of maize. Indonesian Journal of Crop Science, v.5, p.1-11, 1990.

SUBANDI; COMPTON, W.A. Genetic studies in an exotic population of corn (Zea mays L.) grown under two plant densities. I. Estimates of genetic parameters. Theoretical and Applied Genetics, v.44, p.153-159, 1974.

TERRAZAS, J,M.; VELASCO, W.; AVILA, G.; AVILA, L.G. CESPEDES, P.LM. Response to irrigation and water stress condition during the first stage of crop development in full-sib families of a maize variety from the highland zone. In: REUNION LATINOAMERICANA, 3.; REUNION DE LA ZONA ANDINA DE INVESTIGADORES EN MAIZ, 16., Cochabamba, Bolívia, 1995. Memorias. Cochabamba: CIFP, 1995. p.249-266. 
TEYKER, R.H.; MOLL, R.H.; JACKSON, W.A. Differences among prolific maize hybrids in the effects of lower leaf removal. Maydica, v.36, p.1-10, 1991.

THOMISON. R.R.; JORDAN. D.M. Plant population effects on corn hybrids differing in ear growth habit and prolificacy. Journal of Production Agriculture, v.8, p. 394-400, 1995.

TOLLENAAR, M. Sink-source relationships during reproductive development in maize: A review. Maydica, v.22, p.49-75, 1977.

TOLLENAAR, M.; DWYER, L.M.; STEWART, D.W. Ear and kernel formation in maize hybrids representing three decades of grain yield improvement in Ontario. Crop Science, v.32, p.432-438, 1992.

TORREGROZA, M. Response of a highland maize synthetic to eleven cycles of divergent mass selection for ear per plant. Agronomy Abstract, p.16, 1973.

TORREGROZA, M.; HARPSTEAD, D.D. Effects of mass selection for ears per plant in maize. Agronomy Abstract, p.20, 1967.

TSOTSIS, B. Objectives of industry breeders to make efficient and significant advances in the future. In: ANNUAL HYBRID CORN INDUSTRIAL RESEARCH CONFERENCE, 27., Chicago, 1972. Proceedings. Chicago: American Seed Trade Association, 1972. p.140-158.

UNDERSANDER, D.J. Yield and yield component response of maize to water stress in hybrids with different sources of stress tolerance. Maydica, v.32, p.49-60, 1987.

VALOIS, A.CC.; MIRANDA FILHO, J.B. Comparação entre métodos de seleção em milho cv. Centralmex. Pesquisa Agropecuária Brasileira., v.19, p.169-177, 1984. 
VASCO MEDINA, A.S. Avaliação de híbridos simples de milho (Zea mays L.) obtidos de linhagens com diferentes graus de endogamia. Piracicaba, 1990. 210p. Dissertação (Mestrado) - Escola Superior de Agricultura "Luiz de Queiroz", Universidade de São Paulo.

VEIT, B.; SCHIMIDT, R.J.; HAKE, S.; YANOFSKY, M.F. Maize floral development: new genes and old mutants. The Plant Cell, v.5, p.1205-1215, 1993.

VENCOVSKY, R.; BARRIGA, P. Genética biométrica no fitomelhoramento. Ribeirão Preto: Revista Brasileira de Genética, 1992. 496p. 